Illinois State University

ISU ReD: Research and eData

Theses and Dissertations

$11-1-2013$

\title{
The Function of a Middle Woodland Site in the Central Illinois Valley: A Ceramic Study of Ogden-Fettie
}

Montana L. Martin

Illinois State University, mlmart3@ilstu.edu

Follow this and additional works at: https://ir.library.illinoisstate.edu/etd

Part of the History of Art, Architecture, and Archaeology Commons

\section{Recommended Citation}

Martin, Montana L., "The Function of a Middle Woodland Site in the Central Illinois Valley: A Ceramic Study of Ogden-Fettie" (2013). Theses and Dissertations. 60.

https://ir.library.illinoisstate.edu/etd/60

This Thesis is brought to you for free and open access by ISU ReD: Research and eData. It has been accepted for inclusion in Theses and Dissertations by an authorized administrator of ISU ReD: Research and eData. For more information, please contact ISUReD@ilstu.edu. 


\title{
THE FUNCTION OF A MIDDLE WOODLAND SITE IN THE CENTRAL ILLINOIS
}

\section{VALLEY: A CERAMIC STUDY OF OGDEN-FETTIE F 196}

\author{
Montana L. Martin
}

147 pages

December 2013

Ogden-Fettie is a Middle Woodland Havana-Hopewell mound group in the Central Illinois Valley. $\mathrm{F}^{\mathrm{v}} 196$ is the midden area near the largest mound. The function of $\mathrm{F}^{\mathrm{v}} 196$ is in question, because it does not conform to the settlement and function models that have been applied to other sites. The ceramic collection from $\mathrm{F}^{\mathrm{v}} 196$ was typed and categorized into categories based on perceived function, either habitation or ceremonial. The majority of the pottery belonged to the Havana series, which is traditionally considered habitation pottery; however, many of the Havana sherds are decorated indicating a ceremonial function. The highly decorated pottery suggests $\mathrm{F}^{\mathrm{v}} 196$ was a point aggregation that hosted rituals related to mound construction. There was great variation in the decoration types at Ogden-Fettie. Many of the decorations seen on pottery from $\mathrm{F}^{\mathrm{v}} 196$ are not present at other Havana-Hopewell site. The great diversity in decoration types showed $\mathrm{F}^{\mathrm{v}} 196$ was a gathering location for disparate groups who brought uniquely decorated pottery.

The ceramic collection from Ogden-Fettie suggests the site shows a continuum of occupation from the Early Woodland up to Historic times. A small portion of the ceramic assemblage is represented by sherds exhibiting traits of two types of pottery. 
There are also some sherds which have traits of both Black Sand and Havana ceramics which showed a blending of the Early Woodland and the Middle Woodland cultures. The diverse decorations in conjunction with the mixed trait Havana sherds shows OgdenFettie may be one of the first Havana aggregation sites. 
THE FUNCTION OF A MIDDLE WOODLAND SITE IN THE CENTRAL ILLINOIS VALLEY: A CERAMIC STUDY OF OGDEN-FETTIE F 196

MONTANA L. MARTIN

A Thesis Submitted in Partial

Fulfillment of the Requirements for the Degree of

MASTER OF SCIENCE

Department of Sociology and Anthropology

ILLINOIS STATE UNIVERSITY

2013 
All rights reserved

INFORMATION TO ALL USERS

The quality of this reproduction is dependent upon the quality of the copy submitted.

In the unlikely event that the author did not send a complete manuscript and there are missing pages, these will be noted. Also, if material had to be removed, a note will indicate the deletion.

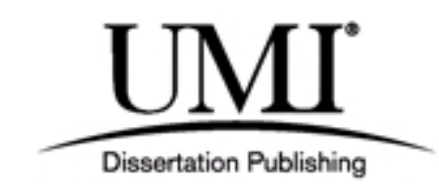

UMI 1552475

Published by ProQuest LLC (2014). Copyright in the Dissertation held by the Author.

Microform Edition () ProQuest LLC.

All rights reserved. This work is protected against unauthorized copying under Title 17, United States Code

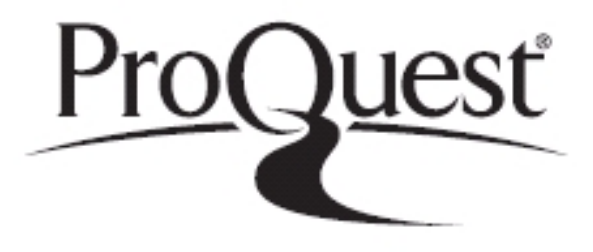

ProQuest LLC.

789 East Eisenhower Parkway

P.O. Box 1346

Ann Arbor, MI 48106 - 1346 
(C) 2013 Montana L. Martin 
THE FUNCTION OF A MIDDLE WOODLAND SITE IN THE CENTRAL ILLINOIS VALLEY: A CERAMIC STUDY OF OGDEN-FETTIE F 196

\author{
MONTANA L. MARTIN
}

COMMITTEE MEMBERS:

James M. Skibo, Chair

Michael D. Wiant 


\section{ACKNOWLEDGMENTS}

Everyone I have met in my academic career has contributed in some way to my thesis, but I only have space to mention a few. I would first like to thank my family for financial and emotional support in all of my educational endeavors and for instilling a curiosity about the world that has led me to this point. Thank you to Sheila Skulborstad for reading and editing multiple drafts of this thesis. I would like to thank my fellow graduate students Collin Gillenwater and Jessica Albrecht for their friendship, guidance, and contributions to my knowledge of archaeology. Thanks to the Illinois State Museum for the loan of the Ogden-Fettie collection. Thanks also to Alexey Zelin, Dr. Andrew Fortier, and the ISAS organization for providing lab space and their expertise in ceramic analysis. Thank you to Ken Farnsworth for sharing his knowledge and expertise of Middle Woodland ceramics and culture. Thanks to my thesis committee members, Dr. James Skibo for initiating me into the world of ceramic analysis, and Dr. Michael Wiant for his wisdom and encouragement, which have shaped my academic and personal experience.

Without your assistance this thesis would not have been possible. You have all enriched my experience in graduate school. Thank you. 


\section{CONTENTS}

$\begin{array}{lr} & \text { Page } \\ \text { ACKNOWLEDGMENTS } & \text { i } \\ \text { CONTENTS } & \text { ii } \\ \text { TABLES } & \text { iv } \\ \text { FIGURES } & \mathrm{v}\end{array}$

CHAPTERS

I. SITE DESCRIPTION AND RESEARCH MODEL 1

$\begin{array}{ll}\text { Research Model } & 7\end{array}$

Research Questions $\quad 10$

How did $\mathrm{F}^{\mathrm{v}} 196$ Function? 10

What Percent of the Havana Pottery is Decorated? 11

Is Ogden-Fettie Truly a Unique Site? 11

II. OGDEN-FETTIE AND HAVANA-HOPEWELL ARCHAEOLOGY 12

Terminology 12

History of Archaeological Investigations 13

Previous Systematic Testing 19

Woodland Period 23

Early Woodland 24

Early Middle Woodland 25

Classic Middle Woodland 26

Late Middle Woodland 26

Late Woodland and Mississippian $\quad 27$

Middle Woodland Settlement and Interaction 27

III. METHODS AND COMPARATIVE REVIEW 30 
Methods 31

Comparative Review 39

Early Woodland $\quad 39$

Middle Woodland Ceremonial 40

Middle Woodland Habitation $\quad 45$

Middle Woodland Special Purpose 49

IV. OGDEN-FETTIE ARTIFACT ANALYSIS 52

Middle Woodland Pottery 53

1959 Struever and Wettersten Surface Collection 54

1959 Struever and Wettersten Excavation 56

1961 DeBusk Surface Collection $\quad 58$

1985 NYU Excavations $\quad 59$

Compiled Fv 196 Ceramics $\quad 67$

$\begin{array}{ll}\text { Mound } \mathrm{F}^{\mathrm{o}} 191 & 70\end{array}$

$\begin{array}{ll}\text { Non-Middle Woodland Pottery } & 70\end{array}$

Mound $\mathrm{F}^{\mathrm{o}} 188 \quad 70$

$\begin{array}{ll}\mathrm{F}^{\mathrm{v}} 196 & 73\end{array}$

$\begin{array}{ll}\text { Non-Ceramic Artifacts } & 74\end{array}$

$\begin{array}{lll}\text { V. SITE FUNCTION AND FORMATION } & 77\end{array}$

When was Ogden-Fettie Occupied? 77

How did $\mathrm{F}^{\mathrm{v}} 196$ Function? $\quad 81$

Havana Fine $\quad 91$

Is it Unique? $\quad 94$

Conclusions $\quad 96$

Future Research 98

$\begin{array}{ll}\text { REFERENCES } & 101\end{array}$

$\begin{array}{ll}\text { APPENDIX A: Typology } & 110\end{array}$

$\begin{array}{ll}\text { APPENDIX B: Sherd Totals by Excavation } & 127\end{array}$

$\begin{array}{ll}\text { APPENDIX C: Decoration Total } & 130\end{array}$

APPENDIX D: Ceramic Series and Decoration Types 133 


\section{TABLES}

Table $\quad$ Page

1. Percentage of Decorated Havana Pottery by Site 50

2. Sherd Totals from 1985 Excavation Blocks 62 


\section{FIGURES}

Figure $\quad$ Page

1. Selected Central Illinois Valley Middle Woodland Site Locations 2

2. Ogden-Fettie Mounds and Middens 4

3. Photograph of Historic 1884 Home on $\mathrm{F}^{\mathrm{o}} 175$

4. Burial and Crematorium Inside of $\mathrm{F}^{\mathrm{o}} 175 \log \mathrm{Tomb} \quad 16$

5. 1957 Aerial Photograph of $\mathrm{F}^{\mathrm{o}} 175, \mathrm{~F}^{\mathrm{v}} 196$, and the 'enclosure' F197 18

6. Illinois Valley Site Locations 38

7. Total Surface Collected Sherds Struever 1959

8. Total Excavated Sherds Struever 1959

9. Total Surface Collected Sherds DeBusk 1961

10. Topographic Map Showing Previous Excavations of Ogden-Fettie 61

11. Sherd Totals by Excavation Block Winters 1985

12. Total Excavated Sherds from All Features Winters 1985

13. Total Rim Sherds from Excavations Winters 1985

14. Total Sherds from all Archaeological Investigations of $F^{v} 196 \quad 67$

15. Early Woodland Type Indeterminate Sherds from $\mathrm{F}^{\circ} 188$

16. Black Sand Sherds $\quad 72$

17. Havana Sherd from $F^{\circ} 188$

18. Excavations of Mound $\mathrm{F}^{\circ} 188$ 
19. Exotic Lamellar Blades

20. Warsaw Tabular Chert Points

21. Mixed Trait Sherd

80

22. Mound Fill from $F^{\circ} 175$

89 


\section{CHAPTER I}

\section{SITE DESCRIPTION AND RESEARCH MODEL}

The Havana mound group, known as Ogden-Fettie, is a Middle Woodland site of around thirty five Havana mounds (Figure 1) located in the floodplain of the Illinois River (Figure 2) near Lewistown, Illinois (Cole and Deuel 1937; Sheilds n.d.). Although there have been a number of amateur and professional archaeological investigations, the work has yielded only a few published reports and thus we know little about the prehistory of the site (Cantwell 1980; Cole and Deuel 1937; Hennessey 1988; Holt 2000; Wettersten 1960). The archaeological material from five archaeological investigations (Cole and Egan in 1931; Deuel and Egan in 1931; Struever in 1959; DeBusk in 1961; and Winters in 1985) of Ogden-Fettie (11F $166-191$ and 886-889) housed at the Dickson Mounds Museum serve as the serve as the primary data set for the analysis focused on determining the function (habitation or ceremonial) of the site based upon the model first proposed by Struever in his dissertation (1968a) and article (1968b).

The largest mound at Ogden-Fettie is referred to as " $\mathrm{F}^{\circ} 175$ " and is near the midden area known as " $\mathrm{F}^{\mathrm{v}} 196$," which has an undetermined function (Cole and Deuel 1937). The burial furniture from the mounds shows that some of the mounds at OgdenFettie were constructed during the Early Woodland Period by people of the Black Sand culture and others were built during the early Middle Woodland by people of the Havana 
culture (Farnsworth personal comm.; Sheilds n.d.). Ogden-Fettie is believed to be one of the most important, unique, and early Havana-Hopewell sites in Illinois, but the significance of the site is based on little evidence (Cole and Deuel 1937; Farnsworth personal comm.; Shields n.d.:1). While the mounds appear to have been built during the Early Woodland and early Middle Woodland Periods, Fv196 appears to have been used most heavily after the mounds were built.

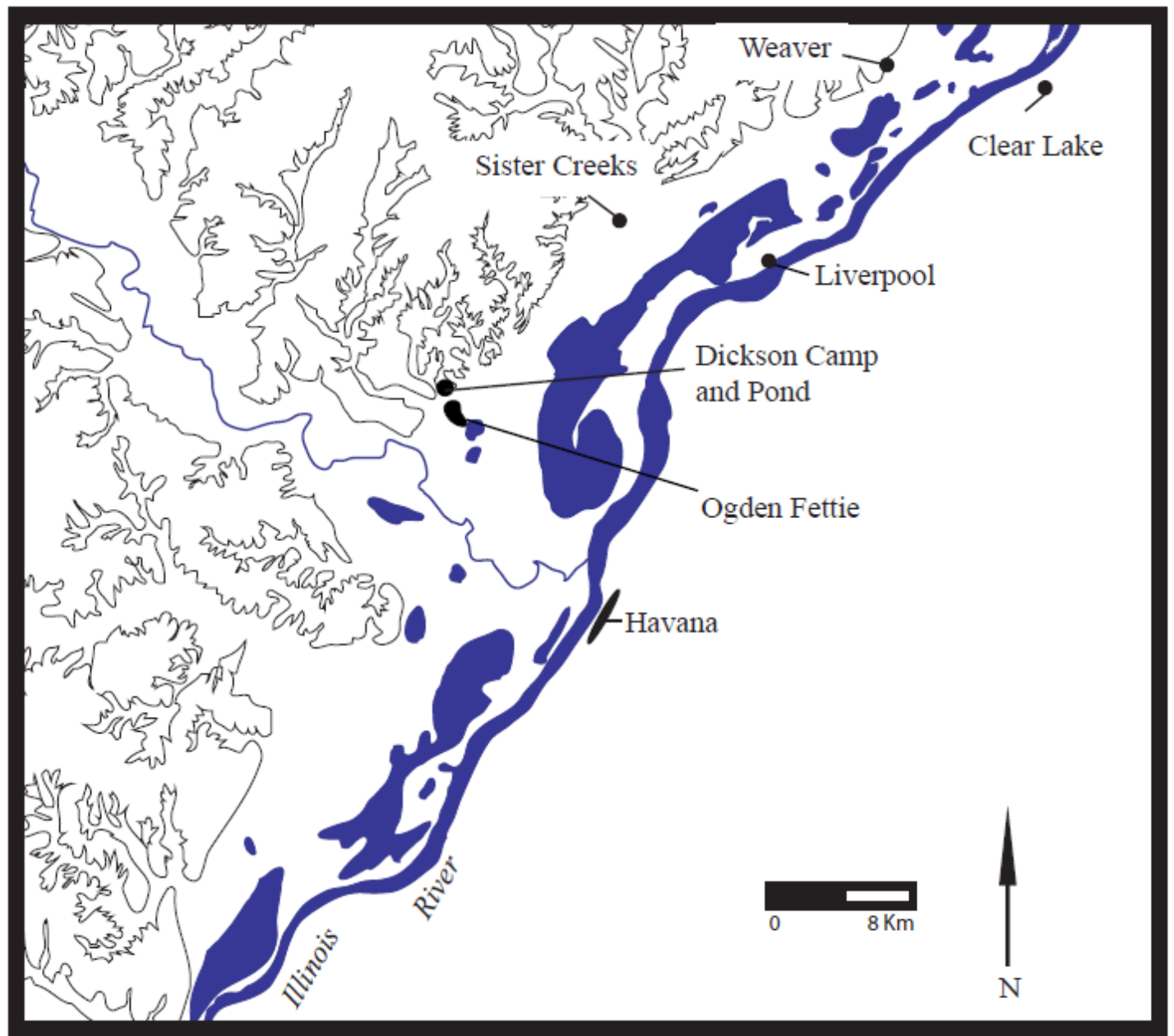

Figure 1: Selected Central Illinois Valley Middle Woodland Site Locations (Cantwell 1980; USGS 2012) 
Ogden-Fettie is one of a host of excavated Illinois Valley Havana-Hopewell sites. It is located in the Central Illinois River Valley, where most excavated Havana-Hopewell sites are multicomponent. Multi-occupational sites pose a problem because they have mixed context middens where there is little to no stratigraphy, so relative dating is inaccurate. To infer the activities preformed near mound $\mathrm{F}^{0} 175$ that created $\mathrm{F}^{\mathrm{v}} 196$, I sorted and analyzed ceramic assemblage and applied these data to Struever's (1968b) model to determine the function of the site. These data were compared with other Middle Woodland sites to explore whether Ogden-Fettie is an important, unique, and early Havana-Hopewell site as others have stated. (Braun 1977; Braun et al. 1982; Cantwell 1980; Cole and Deuel 1937; Epstein 1951; Fortier 2004; Fortier 1989; Griffin 1952; McGregor 1952; Morgan 1985; Morgan 1986; Morse 1963; Wray and MacNeish 1961). 


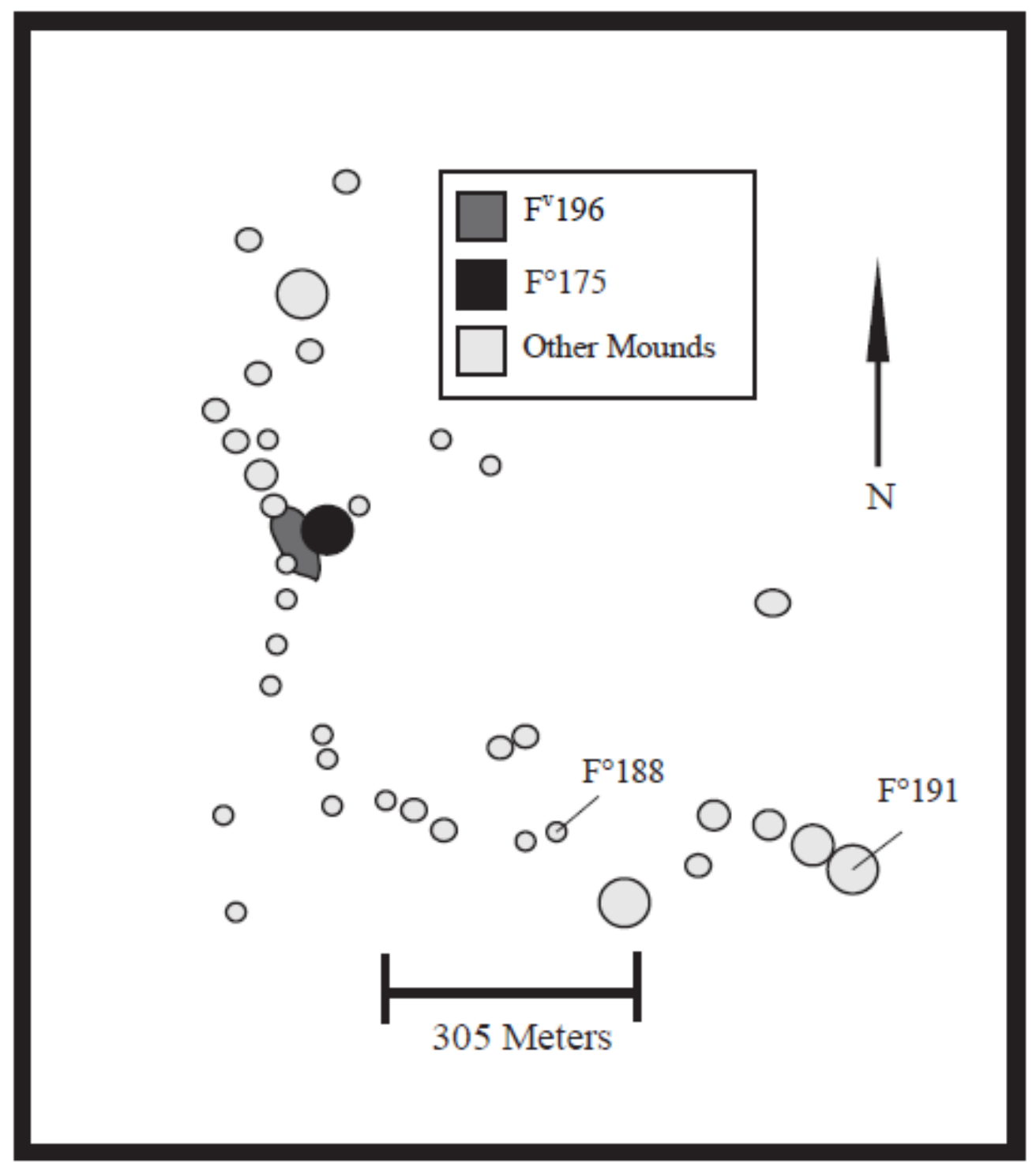

Figure 2: Ogden-Fettie Mounds and Middens (Cole and Deuel 1937)

Struever's (1968b) settlement model provides a way to determine the function of sites based upon the relative proportions of pottery presumed to be used in secular or ceremonial contexts (Braun 1977; Morgan 1985; Morgan 1986). Previous research has asserted that thick Havana and Pike pottery was used for secular purposes and thin 
Hopewell, Baehr, and Havana Fine pottery used in a ceremonial setting (Braun 1977; Braun et al. 1982; Epstein 1951; Fortier 1989; Griffin 1952; Maher 1989; McGregor 1952; Morgan 1985; Morgan 1986; Staab 1984; Struever 1968a; Struever 1968b).

The pottery types were tabulated for Ogden-Fettie, and then Struever's (1968b) model was applied to understand the function of Ogden-Fettie $\mathrm{F}^{\mathrm{v}} 196$. The model asserted that sites containing large proportions of Havana and Pike pottery were habitation sites and sites yielding large amounts of Hopewell and Baehr pottery were ceremonial sites. Struever (1968b) is easily applicable to most Lower Illinois Valley sites; however, it is poorly suited for inferring the function of Central Illinois Valley sites such as OgdenFettie. The model assumes that ceramic series can be linked to function. The analysis conducted as part of this study, however, considers the possibility that some pottery (Havana and Havana Fine) exists within two functional realms, ceremonial and habitation. The Struever (1968b) model, though useful, is found to be too narrowly defined and I suggest adding an additional site function, "Aggregation Site" to make it more applicable to $\mathrm{F}^{\mathrm{v}} 196$. Decorated Havana sherds were counted and the percentage was applied to the modified Struever (1968b) model to test the possibility $\mathrm{F}^{\mathrm{v}} 196$ was an Aggregation Site with a feasting function.

Ogden-Fettie is one of a few unique Havana-Hopewell sites in the Central Illinois Valley. Its uniqueness comes from the function and age of the site. My analysis revealed the site was occupied during the Early, Middle, and Late Woodland, and at least once during the Mississippian period, showing a continuum through time, which is unusual for sites of this type. I also found $\mathrm{F}^{\mathrm{v}} 196$ was a gathering location where diverse and isolated 
groups met to participate in rituals. The site had a diverse decorated ceramic assemblage suggesting it was an Aggregation Site.

Chapter II gives a background of the Middle Woodland and Ogden-Fettie. It begins by explaining the terminology that is used in this paper to distinguish specific cultural features of Ogden-Fettie. Previous archaeological work conducted at OgdenFettie is also discussed along with a review of the Woodland Period adaptation and the settlement patterns of the Middle Woodland.

Chapter III describes the excavation techniques used by others to recover the material and to provide some context to the pottery used in the study. I also discuss the methods I employed in the collection of data that serves as the core of my analysis. The Middle Woodland ceramic assemblage data from selected Middle Woodland sites is compiled and compared to Ogden-Fettie to assist in determining site function.

In Chapter IV the results from the analysis of the $\mathrm{F}^{\mathrm{v}} 196$ ceramic assemblage and selected other artifacts are discussed. The ceramic analysis is discussed in sections based on collection method and date. Other ceramics, artifacts, and site features are discussed as additional information used to understand site function.

The conclusions reached during my analysis are discussed in Chapter V. This includes an examination of the timing of the occupation of Ogden-Fettie and $\mathrm{F}^{\mathrm{v}} 196$ and my conclusions about site function. Then the function is determined using the pertinent information from this thesis. The new "Havana Fine" type of ceramics is also discussed and some suggestions for future research. 


\section{Research Model}

In order to understand the function of the midden $\mathrm{F}^{\mathrm{v}} 196$ this paper analyzes the pottery and a select few other artifacts gathered during Struever's 1959 surface collection and excavation, DeBusk 1961 surface collection, and the material from the 1985 Winters excavation. I also consider the artifacts from the excavations of mounds $\mathrm{F}^{\circ} 188$ and $\mathrm{F}^{\mathrm{o}} 191$ as they will assist in understanding the site formation and age. The goal of the analysis is to interpret the intended function of the Middle Woodland archaeological remains, either a ceremonial, habitation, or special purpose function (Stafford and Sant 1985; Skibo 2012; Struever 1968a; Struever 1968b; Wiant and McGimsey 1986).

In Struever's (1968b) article Woodland Subsistence-Settlement Systems in the Lower Illinois Valley he defined three types of Middle Woodland sites, Ceremonial, Habitation, Regional Trade Centers, and Special Purpose/Resource Gathering (Struever 1968b). Ceremonial sites are described by a low occurrence of subsistence remains, few pit features, low numbers of subsistence tools, high number of ritual lamellar blades, low artifact density, and a high proportion of ceremonial pottery series of Hopewell, Baehr, and Havana Fine (Morgan 1985; Morgan 1986; Struever 1968a; Struever 1968b). There are two categories of Ceremonial sites, bluff-top and Floodplain Mortuary Camps. An example of a bluff-top Mortuary Site is Elizabeth Mounds (11-PK-512) and the associated Napoleon Hollow (11-PK-500) Block IV Mortuary Camp (Charles et al. 1988; Wiant and McGimsey 1986). While the sites of Peisker (11-C-135), Kamp (11-C-12), and Sister Creeks are three examples of Floodplain Mortuary Camps (Buikstra 1976; Buikstra et al. 1998; Meinkoth 1995; Ruby et al. 2006; Struever 1960). Bluff-top 
Mortuary Sites are usually associated with habitation sites and would appear to service the mortuary needs of the habitation sites. Floodplain Mortuary Camps usually have a light scatter of subsistence remains, because they were used as settlements during the construction of mounds (Buikstra 1976; Buikstra et al. 1998; Staab 1984; Struever 1968b). A habitation site will have an abundance of subsistence remains, many pit features, a wide variety of tools, areas of high artifact density, and the habitation ceramics belonging to the Havana and Pike series (Morgan 1985; Morgan 1986; Struever 1968a; Struever 1968b). Examples of Habitation sites would be Smiling Dan (11-ST-123), Dickson Camp, and Pond (11-F-10). Regional Transaction Centers are represented by sites with large amounts of long distance trade items, and Struever (1968b) identified Mound House (11-GE-7) as an example and Struever and Houart (1972) believed OgdenFettie was another. Finally, Special Purpose/Resource Gathering sites have specialized tools, low numbers of subsistence/cooking materials, and low artifact densities (Struever 1968b). The Pond site on a bluff overlooking Ogden-Fettie is possibly a Special Purpose/Resource Gathering site; but this designation is not completely verified (Cantwell 1980).

The ability of Struever's (1968b) model to predict site function has been tested on a few occasions (Staab 1984; Wiant and McGimsey 1986). Wiant and McGimsey (1986) looked at the Napoleon Hollow site, which is located at the base of a bluff in the Lower Illinois Valley (Figure 6). Napoleon Hollow Block IV is directly down the bluff slope from Elizabeth Mounds and across the river from Smiling Dan. The site had a large percentage of well-made Hopewell and a large percentage of the Havana sherds were 
decorated. These factors along with faunal remains, few pit features, and the presence of ritual lamellar flakes confirmed the Struever (1968b) model and suggested that the site had a ceremonial function.

Staab (1984) re-examined the Peisker site. She found the site had a high percentage of Havana pottery and many subsistence remains, refuting Struever's (1968b) assertion that it was a mortuary camp. Instead Staab (1984) interpreted the site as having a habitation function. She also identified a ceremonial type of Havana pottery, which has been found at a few other sites usually associated with burial contexts (McGregor 1952; Taylor 1929). The ceremonial variety of Havana pottery does not change the function alone, because known habitation sites often have both ceremonial and secular ceramics. The burial pots are generally finely constructed and highly decorated pots with small orifice diameters. Staab (1984) proposed to call the ceremonial Havana pottery "Hardin Series" and believed the pottery represented the early and late Havana culture when Hopewell pottery was not available. The definition of Hardin series as both early and late Havana is too ambiguous and thus generally has not been accepted, so I have adopted the name "Havana Fine" and have given a more specific definition. Havana Fine pottery has characteristics of both Havana and Hopewell pottery and is often found in ceremonial burial contexts (Staab 1984). There appears to be a dichotomy between ceremonial Havana Fine pots and secular Havana pots similar to the dichotomy of Havana and Hopewell pots. Havana Fine pottery appears to have come from the early Havana culture before Hopewell pottery was widely used. The early timing may have adverse consequences for the applicability of the model, as it was designed for the Havana- 
Hopewell culture and not earlier time periods. The recognition of ceremonial Havana sherds questions the assumptions that are germane to the Struever (1968b) model. While the existence of these sherds questions the original model, they also represent an opportunity to refine the model.

As archaeologists have accumulated more information about this period, it is evident that the Struever model cannot be applied as easily as first intended. Instead of abandoning the model, however, I recommend that the model can be modified and still be very useful. I believe that another type site, an Aggregation Site needs to be added to the model. An Aggregation Site is represented by a high proportion of Havana cooking ceramic remains, more than $30 \%$ of the Havana sherds will be decorated, and some may have a pottery with a diverse collection of temper and decorations. There will be few and shallow pit features as the sites are only occupied for short durations. Sites fitting this description have only been observed at sites associated with mounds, so they appear to be related to burial rituals. This additional site function is still a working hypothesis and it will be interesting to see if other sites besides Ogden-Fettie will have these types of characteristics and thus suggest that a Ritual Feasting Site type may be more widely found.

\section{Research Questions}

How did $F^{v} 196$ Function? To answer the question of function, I cataloged and categorized the entire ceramic assemblage from $\mathrm{F}^{\mathrm{v}} 196$. I then separated the pottery into two functional groups consisting of five total series; the ceremonial functioning ceramics were the Havana Fine, Hopewell, and Baehr series, while the Havana and Pike series 
sherds were considered to have a secular function. Then the pottery counts were applied to the model from Struever (1968b) and Struever and Houart (1972) to determine the function of $F^{v} 196$. The alternative functions proposed by Winters (1981) and Staab (1984) were also considered.

What Percent of the Havana Pottery is Decorated? The percentage of decorated pottery will inform on the function of $\mathrm{F}^{\mathrm{v}} 196$. It will also help to differentiate between aggregation (high percent of decorated sherds) and habitation (low percent of decorated sherds) sites, because both have high numbers of Havana sherds.

Is Ogden-Fettie Truly a Unique Site? It has been claimed that Ogden-Fettie is a unique Havana-Hopewell site, but these claims are based upon little evidence. If it was truly unique then no settlement model would be applicable to both Ogden-Fettie and other Havana-Hopewell sites. To test the claim of uniqueness, the ceramic assemblage was compared with other contemporary pottery assemblages. I looked mainly at percentage of ceramic types and sites locations, with a secondary focus on ceramic variability and some lithic artifacts. 


\section{CHAPTER II}

\section{OGDEN-FETTIE AND HAVANA-HOPEWELL ARCHAEOLOGY}

\section{Terminology}

The official Illinois State Museum designation for Ogden-Fettie is " $11 \mathrm{~F}^{\circ} 166-191$ " and "886-889," but in this research the site is referred to simply as Ogden-Fettie. The name "Ogden-Fettie" comes from the owners, Fred Fettie and Elmer Ogden, of the farm where the mounds and midden area were located.

Components of Ogden-Fettie were identified and numbered by Cole and Deuel (1937) in Rediscovering Illinois: Archaeological Explorations in and Around Fulton County and their numbering system was used in this paper to specify components of Ogden-Fettie. The use of the old numbering system will also allow for easier translation and comparison with previous work that also used the Cole and Deuel (1937) numbering system. Cole and Deuel (1937) used a system of letters and numbers to describe where each component was found. A letter stood for the county of origin, Ogden-Fettie was described by the letter, F for Fulton County, Illinois. The system also employed a super script, which explained the type of site "v" for village and "o" for mound, and finally a unique sequential number was given for every documented village or mound within a county. 
The two numbered components that are referred to extensively throughout the paper are $\mathrm{F}^{\mathrm{v}} 196$ referring to a midden area and $\mathrm{F}^{\circ} 175$ which refers to the largest mound at Ogden-Fettie. A third number F197 is the name of the enclosure encircling $F^{\mathrm{v}} 196$ and Fº175 (Cole and Deuel 1937; Munson 1967; Sheilds n.d.).

History of Archaeological Investigations

Ogden-Fettie is located in the Illinois River Valley near the confluence of the Illinois and Spoon Rivers (Figure 1), and is just down the hill from Dickson Mounds Museum (Cole and Deuel 1937; McCarthy and Chambly 1976; Sheilds n.d.; Stevens 1931). Ogden-Fettie has long been described as an important Havana-Hopewell mound group (Cole and Deuel 1937; Farnsworth 2004; Farnsworth personal communications; Munson 1967; Taylor 1929). Cole and Deuel (1937) documented the site in Rediscovering Illinois and, as noted above, numbered the archaeological site components (Figure 2). Cole and Deuel (1937) stated that Ogden-Fettie consisted of between thirtyone and thirty-five mounds, with the largest being $\mathrm{F}^{\mathrm{o}} 175$, a midden area $\mathrm{F}^{\mathrm{v}} 196$, and two village sites of $\mathrm{F}^{\mathrm{v}} 33$ and $\mathrm{F}^{\mathrm{v}} 35$ better known as Dickson Camp and Pond; the actual number of mounds is unknown, because many of the mounds were lost to plowing (McCarthy and Chambly 1976; Munson 1967; Sheilds n.d.; Stevens 1931).

This research focuses on the midden area known as $\mathrm{F}^{\mathrm{v}} 196$, which is located near the largest mound in the group $\mathrm{F}^{\circ} 175$ (Cole and Deuel 1937; McCarthy and Chambly 1976; Munson 1967; Sheilds n.d.; Stevens 1931). Holt (2000) reports three uncalibrated radiocarbon dates from pit features in the $\mathrm{F}^{\mathrm{v}} 196$ midden area. Two of the dates were close in age at 1850 and $1860+/-60$ years BP, which corresponds to the Middle 
Woodland. The third date was believed to belong to the Late Woodland; it was $1460+/-$ 60 years BP.

The site is located a few hundred meters from the Dickson Camp and Pond sites, which are emergent Havana sites (Cantwell 1980; Cole and Deuel 1937). Based upon relative dating of pottery styles Ogden-Fettie is thought to be one of the earliest HavanaHopewell sites in the Illinois River Valley, however the carbon dates tell a different tale (Cole and Deuel 1937; Farnsworth n.d.; Griffin 1952; Holt 2000).

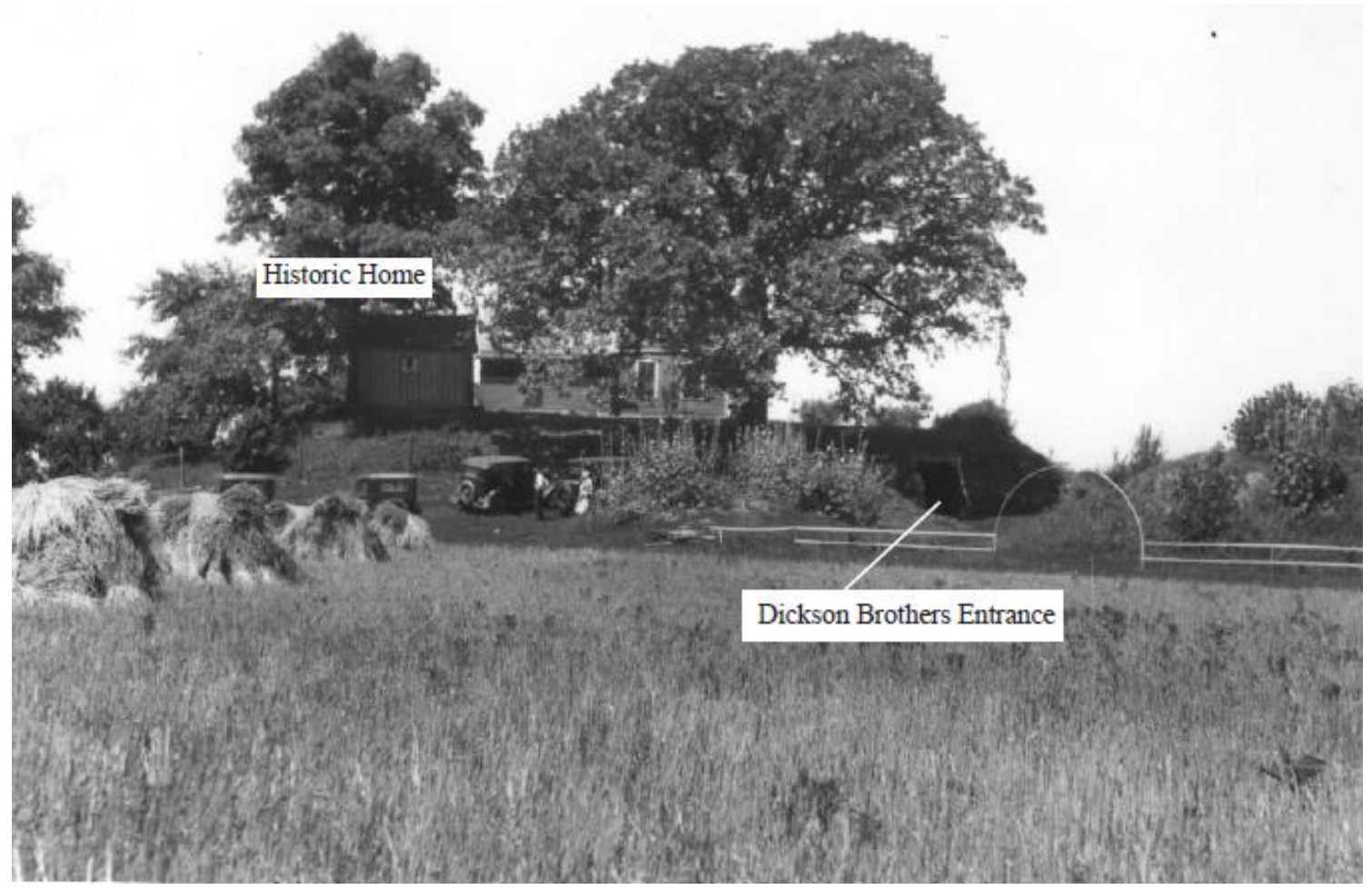

Figure 3: Photograph of Historic 1884 Home on $\mathrm{F}^{\mathrm{o}} 175$ (Collection of Illinois State

Museum; Sheilds n.d.) 
Interest in Native American culture resulted in the excavation of many if not all of the mounds at Ogden-Fettie. The most intriguing excavation was that of $\mathrm{F}^{\circ} 175$. It is the largest of the Ogden-Fettie mounds and because of its imposing size the mound has been the subject of numerous studies (Sheilds n.d.). F $F^{\circ} 175$ has long been known by locals as the Pyramid Mound (Farnsworth 2004; Sheilds n.d.). Over the years the area around $\mathrm{F}^{\circ} 175$ was inhabited by Hopewell, Weaver, Mississippian people, and as well as having three homes constructed on its summit (Cole and Deuel 1937; Farnsworth 2004; Sheilds n.d.).

$\mathrm{F}^{\circ} 175$ was the site of at least three historic home constructions (Sheilds n.d.). During the construction of the cellar for the third and final home (Figure 3) built atop $\mathrm{F}^{\mathrm{o}} 175$, the excavator fell through the ceiling of a log lined tomb, which contained two individuals (Sheilds n.d.). The accidental excavation was quickly closed and the bodies found were reburied elsewhere. The mound was left untouched until 1928 when the Dickson brother attempted to cash in on the growing interest in the past (Sheilds n.d.). In 1928 Marion and Ernest Dickson received a lease to excavate $\mathrm{F}^{\circ} 175$ with the intent of open a museum within the mound (Sheilds n.d.; Cole and Deuel 1937). They began by digging a tunnel into the mound, through a depression in the mound surface (Sheilds n.d.). The Dickson's believed the depression was a prehistoric "hallway" for entering the tomb; the hallway had impressions of small logs and a matted floor (Cole and Deuel 1937; Farnsworth 2004; Sheilds n.d.; Taylor 1929). When the Dickson's opened the museum, they left the bodies and many of the objects in place and allowed people to enter the log lined tomb to see the burials (Figure 4). The exhibit became known as the 
“American Pharos Tomb” (Sheilds n.d.). In 1931 the Dickson's excavated Fv196 which is located near $\mathrm{F}^{\mathrm{o}} 175$ and recovered many decorated pottery sherds (Stevens 1931; Sheilds n.d.).

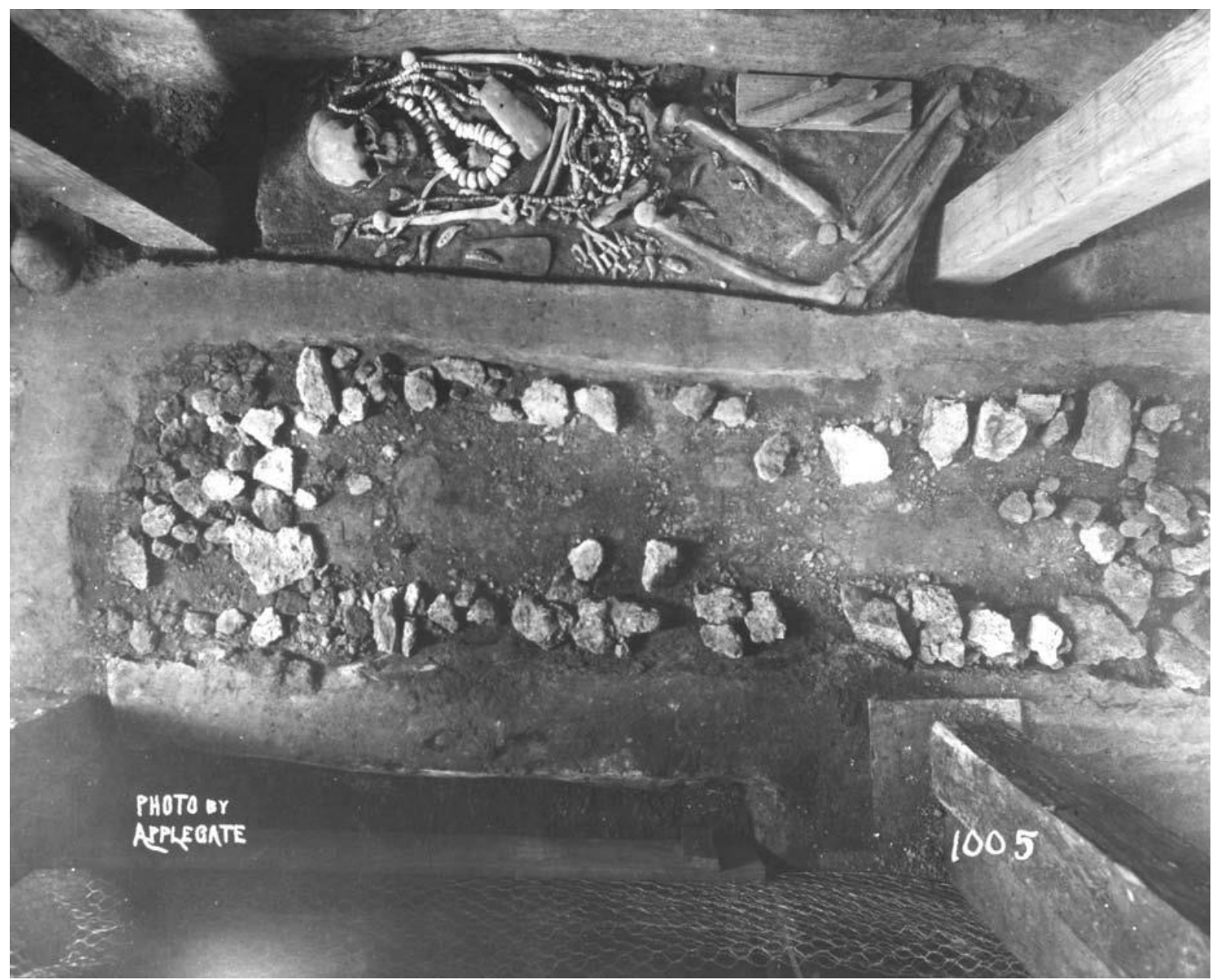

Figure 4: Burial and Crematorium Inside of $\mathrm{F}^{\circ} 175 \mathrm{Log}$ Tomb; these features were part of the Dickson Brothers exhibit (Collection of Illinois State Museum, photographer Applegate; Sheilds n.d.)

In 1929 Jay L.B. Taylor led the University of Illinois excavations of $\mathrm{F}^{\circ} 175$, which was undertaken to verify the uniqueness of Ogden-Fettie (Cole and Deuel 1937; 
Farnsworth 2004; Sheilds n.d.). The excavations confirmed the claims by the Dickson brothers that the mound had mat floor and pole impressions (Cole and Deuel; Sheilds n.d.). The excavations also uncovered a second intrusive Mississippian log tomb that was near the exterior limits of the mound fill (Cole and Deuel 1937; Sheilds n.d.; Taylor 1929). Taylor also excavated the back dirt from the Dickson excavations and found a few Morton sherds (Farnsworth unpublished; Taylor 1929). Fv196 the village site was also surveyed by Taylor (Cole and Deuel 1937; Farnsworth 2004; Sheilds n.d.).

Cole and Deuel (1937:177) described $\mathrm{F}^{\mathrm{v}} 196$ as a village site in "vicinity of the "pyramid" mound" Fº 175 (Sheilds n.d.). F"196 was recognized as having a thick midden and many artifacts suggesting it was a "village" site as opposed to sites with fewer artifacts that were believed to be "camps" (Cole and Deuel 1937; Farnsworth 1990; Farnsworth 2004; Sheilds n.d.). The area was also systematically excavated by Stuart Struever and Vernon Wettersten in 1959, DeBusk in 1961, and a final time in 1985 by Howard Winters and the New York University field school. Of the investigations, only one unpublished report, Wettersten (1960), was produced pertaining to the ceramics. 


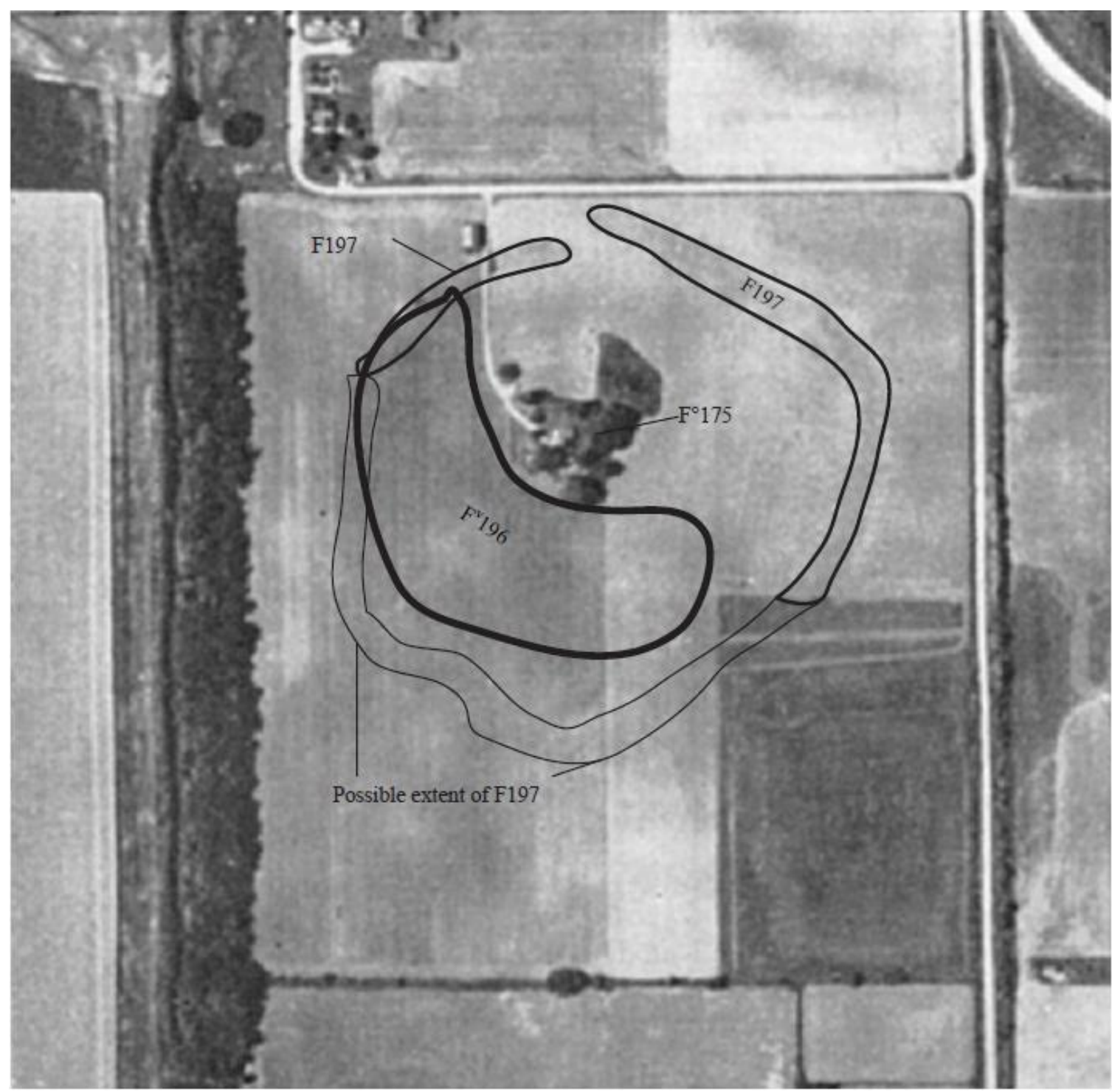

Figure 5: 1957 Aerial Photograph of $\mathrm{F}^{\mathrm{o}} 175, \mathrm{~F}^{\mathrm{v}} 196$, and the 'enclosure' F197 (Agriculture Stabilization and Conservation Service 1957; Munson 1967).

F197 is a controversial geometric earth work has long been referred to as an enclosure or part of a canal system (Sheilds n.d.). F197 generally encloses the area around $\mathrm{F}^{\mathrm{o}} 175$ and a few other mounds. An early account of F197 speculated that it was used for protection against animals, invaders, or as a canal system (Sheilds n.d.). 
Shetrone (1930) referred to F197 as a shallow ditch or moat. Cole and Deuel (1937) cited local tradition calling the depression a waterway, but they speculated that F197 was probably a borrow pit for mound construction. In 1967 Munson drew a reconstruction of F197, by using aerial photographs taken in 1957 and 1963 (Figure 5) (Sheilds n.d.). F197 was again noticed on the 1976 topographic map of Ogden-Fettie created by John McCarthy and Helen Chambly (Sheilds n.d.). There is ample documentation of F197 but, every attempt to excavate the feature has yielded inconclusive results.

Today only a few of the components of Ogden-Fettie are still visible. $\mathrm{F}^{0} 175$ stands around five meters tall and is located in a field owned by the Dickson Mounds Museum. The midden area $\mathrm{F}^{\mathrm{v}} 196$ was a fallow field until 2013 when it was plowed for hay production and a systematic surface collection will be conducted in 2014. The enclosure has been revealed in recent LiDAR images, which depict F197 as having a geometric shape, which suggests a human construction (Wiant personal comm.).

\section{Previous Systematic Testing}

In 1931 Mound $\mathrm{F}^{\circ} 188$ was excavated by a field party including Thorne Deuel and Fred Eggan (Figure 2). Inside the mound there was a pit containing 32 burials (Sheilds n.d.). There were five extended burials placed side by side and the remaining 27 burials were bundle burials placed around the five extended burials (Sheilds n.d.). No skeletal remains were collected, because of extremely poor preservation, which was believed to be in part because of the test holes dug into the mound by Warren King Moorehead in 1928 (Cole and Deuel 1937; Sheilds n.d.). There were no artifacts associated with the burials, but there were 42 pottery sherds, seven blades, one projectile point, one scraper, 
and one hammerstone (Cole and Deuel 1937; Sheilds n.d.). Further excavation notes were unavailable, so little else is known about the mound (Sheilds n.d.).

Mound $\mathrm{F}^{\circ} 191$ was originally tested in 1927 by W. L. Bowman and Thomas Dickson, but was fully excavated in 1931 by Fay Cooper Cole and Fred Eggan (Figure 2) (Sheilds n.d.). The mound yielded nine burials with numerous artifacts, including mica sheets, bear teeth, Warsaw Tabular chert points, copper beads, 10 grit tempered sherds, and a cornstalk. The cornstalk was in undisturbed soil and was believed to belong to have been a mound inclusion (Sheilds n.d.). The artifacts from the mound pointed to an early Middle Woodland construction.

As previously stated, Ogden-Fettie is believed to be a unique, early, and important Havana-Hopewell site (Cole and Deuel 1937; Farnsworth personal communications; Griffin 1952; Sheilds n.d.; Struever 1968b). While the site is very "special" it has not received a lot of professional archaeological attention, probably because there was extensive looting and plowing during the early $20^{\text {th }}$ century that destroyed many of the mounds (Cole and Deuel 1937; McCarthy and Chambly 1976; Munson 1967; Sheilds n.d.; Stevens 1931). The mounds received most of the attention from the looters leaving most of $\mathrm{F}^{\mathrm{v}} 196$ undisturbed, except by plowing, the construction of a driveway, and a few excavations by the Dickson brothers (Cole and Deuel 1937; McCarthy and Chambly 1976; Munson 1967; Sheilds n.d.; Stevens 1931).

As described previously, the Dickson brothers and Taylor were early excavators of Ogden-Fettie, but the first well reported excavations were performed by Stuart Struever and Vernon Wettersten. In 1959 Struever and Wettersten completed test 
excavations on $\mathrm{F}^{\mathrm{v}} 196$ with the intention of using seriation to determine when the site was occupied (Fowler 1952; Wettersten 1960). Another goal of the project was to obtain a sample of Baehr series pottery, for the purpose of comparing it to the variety of Lower Illinois Baehr series pottery (Wettersten 1960). Wettersten (1960) analyzed 2,235 pottery sherds and reported that the site was dominated by Havana pottery (89.50\%) followed by Late Woodland Weaver (8.73\%) and then very small amounts of Hopewell (1.57\%) and Early Woodland Liverpool $(0.23 \%)$. The overwhelming percentage of Havana is not uncommon for a Middle Woodland site, yet according to Struever (1968b) it is unexpected for mound sites. Ogden-Fettie with its high percentage of Havana pottery fits into the habitation category of Struever's (1968b) model. In a more recent paper, Struever and Houart (1972) use Ogden-Fettie as a type site for a Regional Transaction Center, which is described as having many long distance trade items, but they only represent a small part of the Ogden-Fettie assemblage. Wettersten (1960) noted a type of Havana pottery that also had characteristics of Hopewell pottery; I refer to this ceramic type as "Havana Fine" series.

Howard Winters and the 1985 New York University field school excavated Ogden-Fettie $\mathrm{F}^{\mathrm{v}} 196$ and F197. The field school was attempting to test the theory proposed by Winters (1981) that suggested the site may have represented the residences of Havana elites. His theory was predicated on the belief that Middle Woodland society was characterized by early social stratification. He believed the elite residents were supplied with food and other resources by a working class. Holt (2000) tested this theory and found that it was not supported by the faunal remains from the site. 
Preliminary ceramic analysis on the Ogden-Fettie collection was conducted by Winters, but his untimely death in 1994 left the ceramic analysis unfinished (Holt 2000). Hennessy (1988) conducted an analysis of chipped stone. He found that most of the lithics were made from either locally available Avon chert or the semi-local chert varieties of Cobden, Dongola, and Burlington. Interestingly the lamellar blades believed to be associated with Hopewell rituals were primarily made from local chert and semilocal material (Hennessy 1988). The high proportion of local chert is consistent with Struever (1968b) description of a habitation site.

The faunal remains collected from Ogden-Fettie during the 1985 field school were analyzed by Holt (2000). She found that Ogden-Fettie had a large proportion of white tailed deer, which is common at Middle Woodland habitation and ceremonial sites. The assemblage showed no preference for certain cuts of meat, which is indicative of habitation sites. Many of the bones were unmolested by gnawing animals suggesting expedient burial (Holt 2000). Much of the bone was believed to have been burned in a hot fire, with some of them being nearly incinerated. The burning could represent ritual activity; however, the faunal assemblage was non-descriptive because of variable preservation.

Holt (2000) tested two models with her research on Ogden-Fettie $\mathrm{F}^{\mathrm{v}} 196$; the first model was proposed by Struever (1968b), he believed that Ogden-Fettie was only occupied during ritual, ceremonial, and/or exchange rituals. The second model tested was the belief that Ogden-Fettie and Middle Woodland culture had early social stratification and the site was occupied year round by elites or bourgeoisie who were 
supplied with food by the non-elites or proletariat (Holt 2000; Marx and Engels 1848). Holt (2000) found that neither model was supported by the faunal remains at $\mathrm{F}^{\mathrm{v}} 196$. Instead she concluded that the remains from $\mathrm{F}^{\mathrm{v}} 196$ looked extremely similar to the faunal remains gathered at habitation sites like Dickson Camp and Smiling Dan (Cantwell 1980; Hennessy 1988; Holt 2000; Wiant and McGimsey 1986). There was no evidence of selection of meat cuts so that if elites lived on the site they were not supplied with special food. Although habitation artifacts were found, Holt (2000) acknowledged that the presence of mounds showed that Ogden-Fettie was probably used for habitation and mortuary practices.

\section{Woodland Period}

The Woodland Period (Early, Middle, and Late) begins in Illinois with the emergence and widespread adoption of pottery, gardening, and formalized cemeteries (Griffin 1970). The Early Woodland was marked by an increase in pottery used and an increase in population. A hallmark of the Middle Woodland is an increase in population and increased aggregation size. Population increase is a pattern that continued into the Late Woodland; however Late Woodland populations were more dispersed and settlement size decreased (Struever 1968b). Based upon observations of the pottery collected during the archaeological investigations, the importance of Ogden-Fettie grew over time culminating during the Middle Woodland and then decreased into the Late Woodland and Mississippian (Sheilds n.d.; Wettersten 1960; Winters n.d.; Holt 2000). There is great diversity in ceramic types; the types include Crab Orchard, Marion, Black Sand, Morton, Havana, Havana Fine, Hopewell, Weaver, Mississippian, and even 
Modern Crockery (Cole and Deuel 1937; Holt 2000; Sheilds n.d.; Wettersten 1960; Winters n.d.).

Early Woodland. The Early Woodland occupation at the site is marked by the appearance of the distinctive Marion ceramics from the Marion Phase dating from 700 BC to 400 BC (Farnsworth and Asch 1986; Munson 1986). During the Marion Phase there is evidence of trade networks for the acquisition of exotic items often used for burial rites (Munson 1986). Marion sites are usually found on high terraces, and in the Central Illinois Valley Marion habitation sites are extremely rare (Harn 1986; Munson 1986; Munson and Harn 1966). Marion pottery at Ogden-Fettie is represented by only a few potential body sherds, indicating a minor occupation.

Another Early Woodland pottery type present at Ogden-Fettie is Black Sand attributed to the Black Sand culture. The culture was defined by Cole and Deuel (1937) as a unique cultural expression and was named for the dark colored sand ridges that Black Sand sites were built upon. Black Sand pottery is most prominent in the Central Illinois Valley, south of Peoria County and north of Pike County (Cole and Deuel 1937; McGregor 1958; Munson 1986). Black Sand sites usually occur in river valley contexts on the present day shoreline (Cole and Deuel 1937; McGregor 1958; Munson 1986), and Munson (1986) refers to the period when Black Sand pottery is created as the Liverpool Phase (Farnsworth and Asch 1986). The Liverpool Phase dates to approximately 400 to $200 \mathrm{BC}$, but it is hard to define because it blends into the Middle Woodland (Farnsworth and Asch 1986; Munson 1986). Munson (1986) suggests that the Black Sand tradition was not an ancestor of the Havana tradition. Rather, he believes that the Marion tradition 
was the predecessor of Havana (Munson 1986). Munson (1986) suggests this because Black Sand pottery and Havana pottery are morphologically different. Conversely, Farnsworth and Asch (1986) showed that Black Sand decoration styles appear on Morton and Havana pottery, which shows a clear relationship between the cultures. One sherd from Fv196 had a Black Sand rim shape, but exhibited Havana decorations. The sherd suggests a direct relationship between the two pottery traditions.

Early Middle Woodland. The Morton/Caldwell Phase is poorly understood and appears to represent the transition from the Marion and Liverpool Phases of the Early Woodland into the Havana Phase of the Middle Woodland. Morton/Caldwell Phase is a time of immense change, for years the Early Woodland Cultures had been fairly conservative in the cultural expressions of pottery and lithic manufacture. And most Early Woodland burials in Illinois had few associated artifacts, but when the Middle Woodland begins things change rapidly. Most archaeologists note that the Morton/Caldwell Phase was very short and only lasted around 100 years; it ended anywhere from 200 to 50 BC (Cantwell 1980; Farnsworth and Asch 1986; Griffin 1970; Munson 1986). Morton sites occur in more diversified environments than Black Sand sites, being found in river bottoms and on the bluffs (McGregor 1958). There is no consensus on whether the Morton/Caldwell Phase belongs in the Early Woodland or the Middle Woodland. For this paper I tentatively put the Morton/Caldwell Phase in the Middle Woodland because it displays many of the mortuary characteristics present in Havana society. The short duration of the Morton/Caldwell Phase saw the increasing complexity in pottery decoration, which set the stage for the ornate Hopewell and Havana 
vessels (Griffin 1970; Farnsworth and Asch 1986).

The Fulton Phase represents the beginning of Havana pottery tradition. According to Griffin (1970: 4) the Fulton Phase dates to around 150 BC to AD 1. Pottery during this time may still exhibit some of the same decorations seen in the Morton/Caldwell Phase, but the pottery is morphologically different (Farnsworth 1986; Munson 1986). Hopewell pots were not used during this phase, so Havana vessels were used in secular and ceremonial contexts (McGregor 1952; Taylor 1929). There is great variation in decorations that appear on Havana vessels from the Fulton Phase. Near the end of the phase much of the decoration diversity had disappeared and was replaced by traditional Havana pottery designs.

Classic Middle Woodland. The Ogden Phase begins around AD 1 and runs to AD 150 (Griffin 1970: 4). The Ogden Phase is characterized by the classic Havana-Hopewell pottery and ritual remains. Long distance trade items become more prevalent during this period. During this phase Havana and Hopewell pots were created, both of which appear to have production rules regarding the creation and decoration of pots (Fortier personal comm.). It is also believed that the two classes of pots functioned differently (Morgan 1985; Morgan 1986; Skibo 2012; Struever 1968b; Struever and Houart 1972). During this phase Havana pottery was no longer used for ritual purposes, and instead was used in only in secular arenas, while Hopewell vessels were used in the ceremonial sphere (Griffin 1952; Struever 1968).

Late Middle Woodland. The Steuben Phase, the last of the Havana-Hopewell Phases, begins at AD 150 and ends AD 400 (Griffin 1970: 4). In the Lower Illinois 
Valley it is known as the Pike Phase and is marked by the presence of Pike and Baehr series pottery (Farnsworth and Asch 1986). Pike and Baehr series pottery are believed to be a degeneration of the stylistic ideo-function of Havana and Hopewell pottery (Morgan 1985; Skibo 2012). In the Central Illinois Valley this time is not well defined, because most sites have a mixture of Middle Woodland phases. Generally, the Steuben Phase is defined by the presence of limestone tempered Pike and Baehr pottery and/or the presence of Baehr brushed vessels.

Late Woodland and Mississippian. The Middle Woodland ends around AD 400 and gives way to the Late Woodland (Griffin 1970: 4). The Late Woodland pottery represented in the Central Illinois Valley is known as Weaver. Weaver pottery has a lot in common with Havana and Hopewell pottery, the main difference is that it is usually more poorly made and often is only decorated with cord marking. However, at OgdenFettie the pottery is usually smoothed and may represent the transition from Havana to Weaver pottery. The Mississippian follows the Late Woodland beginning around AD 1000 and has diagnostic shell tempered pottery.

\section{Middle Woodland Settlement and Interaction}

Since the mid-1800s there has been much speculation about Havana-Hopewell settlement patterns and trade relations. Bruce Smith (1992) explained that the characteristic large Havana-Hopewell villages recognized by Cole and Deuel (1937) were actually gathering sites. Ruby et al. (2006) believes that most Havana-Hopewell people probably lived in small farming groups or hamlets, not large villages. Havana-Hopewell people gathered at the "large village sites" and participated in community building rituals 
such as mound construction (Dillehay 1990; Hayden 2003; Ruby et al. 2006; Smith 1992). Ruby et al. (2006) suggested that there were three parts to Hopewellian life; the hamlet life, local symbolic, and regional sustainable community. Hamlet life involved the people who lived in or near a farming hamlet (Ruby et al. 2006). Local symbolic groups were groups of hamlets that shared a common communal bluff-top ceremonial/burial site (Ruby et al. 2006). Regional sustainable communities were made up of multiple local symbolic groups that used large floodplain ceremonial/burial sites to create a shared history that would help facilitate marriages, alliances, and exchange of goods (Buikstra 1976; Dillehay 1990; Hayden 2003; Ruby et al. 2006).

Long distance trade and interaction is one of the characteristics common to the Middle Woodland. It is known as the Hopewell Interaction Sphere by Caldwell (1964) and Struever (1964). They explain that groups of Hopewell people interacted in a religious trade network encompassing most of the Eastern Woodlands (Caldwell 1964; Griffin 1979; Seeman 1979; Struever 1964; Struever 1968a). Objects such as platform pipes were traded to distant cultures in return for other ritual objects (Caldwell 1964; Griffin 1979; Seeman 1979; Struever 1964; Struever 1968a). All the platform pipes located in Illinois were believed to have been created in Ohio and traded into Illinois (Farnsworth et al. 2004). However, Farnsworth et al. (2004) showed some Illinois and Ohio pipes were made from Illinois/Wisconsin pipestone. The revelation led research to focus on regional differences, rather than similarities (Griffin 1979; Holt 2000).

A common long distance trade item extensively studied is Knife River Chalcedony. Knife River Chalcedony comes from the Knife River area in Western South 
Dakota (Braun et al. 1982). Conrad (2004) suggests that Knife River material was somewhat common at Middle Woodland sites (Braun et al. 1982). Knife River was an exotic item, but it is more common as a mundane everyday use item than a ritual burial item (Conrad 2004). When it was placed in a burial context it was usually in the form of a used and reshaped biface rather than a pristine blade (Conrad 2004). The single Knife River lamellar blade from Ogden-Fettie was worn, showing it was heavily used. Exchange of ceramics also appears to have taken place during the Middle Woodland (Fie 2006). Crab Orchard Fabric Impressed is a pottery design style that originates from Southern Illinois, but is also found at Smiling Dan in the Lower Illinois Valley (Morgan 1985). Morgan (1985) explained that Crab Orchard Fabric Impressed was present because of trade and a local imitation of pottery production. Other forms such as Sister Creeks Punctate (Central Illinois Valley) and Steuben Punctate (Upper Illinois Valley) also traveled to the Lower Illinois Valley (Fie 2006). Lower Illinois Valley decorations such as Baehr Brushed also make their way North and are found in the Central Illinois Valley, including Ogden-Fettie (Griffin 1952; McGregor 1952; Wray and MacNeish 1961). Baehr and Pike sherds are limestone tempered, so their appearance in the Central Illinois Valley where there are few sources of limestone, strongly suggests ceramic exchange within the Illinois Valley. Many of the Pike and Baehr sherds from Ogden-Fettie were grit tempered suggesting they were locally produced. 


\section{CHAPTER III}

\section{METHODS AND COMPARATIVE REVIEW}

During the first part of the $20^{\text {th }}$ century there was a flurry of archaeological investigations conducted at Central Illinois Valley Havana-Hopewell sites, while the latter half of the century saw the focus shift to the Lower Illinois Valley. The prevalence of Lower Illinois Valley studies in recent years has left a large gap in the literature. Another area lacking in the current studies is the investigation of floodplain mound groups such as Ogden-Fettie, Peisker, and Mound House. The gap appears larger because the floodplain mound groups from the Central Illinois Valley are where the Havana and possibly Hopewell culture first appeared (Cole and Deuel 1937; Farnsworth personal comm.; Stretton 2013).

In this section I compile the Middle Woodland ceramics collected from HavanaHopewell sites (Figure 6), and compare them to Ogden-Fettie (Table 1) to understand the 'uniqueness' of Ogden-Fettie (Sheilds n.d.). In order to put these data into proper context, the archaeological remains from other Middle Woodland sites are first reviewed, and some Early and Late Woodland sites are discussed, because all three parts of the Woodland were present at Ogden-Fettie and they all contributed to the site formation. The focus of the review, however, will be on the Middle Woodland ceramics. The data from the Middle Woodland sites are compiled in Table 1 and Struever's (1968b) 
settlement model is applied to these data.

Methods

The majority of ceramics used in this study come from two site investigations, one by Stuart Struever and Vernon Wettersten, and the other by Howard Winters and the NYU field school. In 1959 Stuart Struever and Vernon Wettersten excavated six test units and labeled them Test Trench 1-6 (TT\#1-6) (Sheilds n.d.; Wettersten 1960). Test Trenches 1-4 and 6 were five foot by five foot squares that were excavated in six inch levels. Test Trench 5 was a 33 foot long trench and it was excavated in one level. The 1985 New York University Field School excavated Ogden-Fettie under the direction of Howard Winters (Holt 2000). They excavated 18 units that were one by one meter squares. Initially, Zone 1, the plow zone, was removed in one level. Then Zone 2 believed to be the undisturbed midden was removed in arbitrary $10 \mathrm{~cm}$ levels. Zone 3 was considered the sterile soil and excavation was ceased when Zone 3 was reached.

Ogden-Fettie has been the focus of multiple amateur and professional archaeological investigations, yet little is known about the prehistory of the site. To begin to understand the function of Ogden-Fettie I have analyzed the collections currently stored at Dickson Mounds Museum in Lewiston, Illinois. The artifact assemblages came from five expeditions at Ogden-Fettie, the 1931 Thorne Deuel and Fred Egan excavation of $\mathrm{F}^{\mathrm{o}} 188$, the 1931 Fay Cooper Cole and Fred Egan excavation of $\mathrm{F}^{\circ} 191,1959$ Struever and Wettersten surface collection and excavation of $\mathrm{F}^{\mathrm{v}} 196,1961$ DeBusk surface collection, and the 1985 Winters excavations of $F^{\mathrm{v}} 196$ and F197. These four excavations and surface collections yielded lithic, faunal, and ceramic assemblages. For 
this thesis I only analyzed the ceramic collections, but noted previous analysis of other artifacts and cataloged selected lithic artifacts. The ceramic analysis was carried out with the ultimate goal of distinguishing whether the site was used for habitation or ceremonial purposes. To date no systematic study of the Ogden-Fettie ceramics has been published, but there is one paper by Wettersten (1960) that analyzed the pottery from the 1959 surface collection and excavations.

Previous Middle Woodland studies (Farnsworth and Kioski 1985; Morgan 1985; Morgan 1986; Struever 1968b; ect.) have asserted that some pottery had a ceremonial function (Hopewell and Baeher series) while others were used for subsistence (Havana and Pike). To understand the activities preformed at Ogden-Fettie, the pottery was be broken down into typological groups using Griffin's (1952) typology.

The typology laid out in Griffin (1952) is general allowing it to be applicable to many sites including those in the Central Illinois River Valley such as Weaver, Sister Creeks, Dickson Camp, and Pond along with others (Cantwell 1980; Meinkoth 1995; Wray and MacNeish 1961). A modified form of Griffin's (1952) analytical strategy was also used at sites elsewhere in Illinois such as Petite Michele, Smiling Dan and Napoleon Hollow (Fortier 2004; Morgan 1985; Morgan 1986; Stafford and Sant 1985; Wiant and McGimsey 1986). The use of Griffin (1952) typology allows this thesis to be understood in the broader context of other Middle Woodland ceramic analysis. I used a modified typology (Appendix A) by adding the series of Havana Fine and clarifying some of the decoration types to make it more applicable to Ogden-Fettie $\mathrm{F}^{\mathrm{v}} 196$ and I have rehashed many of Griffin (1952) original typologies in Appendix A so the guidelines I are clear. 
The pottery analysis was carried out by the author using an enhanced version of Griffin's (1952) typology (Appendix A) supplemented with more recent typologies (Cantwell 1980; Fie 2000; Morgan 1985; Morgan 1986; Saab 1984). There were 1881 sherds from $\mathrm{F}^{\mathrm{v}} 196,38$ sherds from mound $\mathrm{F}^{\circ} 188$, and five sherds from mound $\mathrm{F}^{\circ} 191$. The ceramics from $\mathrm{F}^{\circ} 188$ and $\mathrm{F}^{\circ} 191$ were categorized and cataloged using the modified typology (Appendix A). The ceramic information from the two mounds was used to understand the timing and formation processes of the broader site of Ogden-Fettie.

The 1,876 Middle Woodland sherds from $\mathrm{F}^{\mathrm{v}} 196$ have been divided into categories based upon the perceived function discussed in Struever's (1968b) model. The original classes of Havana and Pike were considered by Struever (1968b) to have been cooking vessels, while Hopewell and Baehr pottery was considered ceremonial. To these original classes I added Havana Fine ceramics to the ceremonial category. The decorations were also counted, because it is proposed that decorated cooking pots could represent the remnants of an aggregation of groups and possibly feasting. Sherds were designated as having a presence or absence of decoration and decoration totals were tabulated to illustrate the variation. A decorated sherd was any sherd that exhibited a surface treatment other than smoothing, cordmarking, smoothed-over cordmarking, brushing, or nodes. All decorations on sherds were counted, not just the most prevalent, because whole pots were not available thus making it impossible to determine the size and prevalence of decorations. The decoration data was used to compare $\mathrm{F}^{\mathrm{v}} 196$ with other Middle Woodland sites to determine if decorated Havana pottery had a ceremonial quality. Finally, the decoration types were used to test the proposition that the greatest 
variation in decoration types happens in the Central Illinois Valley (Farnsworth personal communications). At the conclusion of this project, the tabulated data will be available through the archives at Dickson Mounds Museum for further research.

Braun (1977) studied pottery from multiple Middle Woodland sites to ascertain if there was a relationship between age of pottery and thickness. He gives general guidelines for determining age of sherds by measuring sherd thickness and decoration thickness (Braun 1977: 177). He concluded that thick decorations could only be applied to thick sherds, as thin sherds did not have the structural integrity to accept large decorations. I found no evidence to dispute this claim, but thick sherds also had very thin decorations applied, so thickness was probably only a limiting factor as decorations got larger. Braun (1977) goes on to claim that decoration thickness can be used as an indicator of age, because decoration thickness and sherd thickness decrease over time. This assertion has too many exceptions to be applied reliably, so it was noted, but not used in determining age.

Thickness was also used as a supplemental consideration when determining type of pottery. It was not used exclusively because there are many technical and cultural factors involved in determining vessel wall thickness (Braun 1977; Skibo 2012). As a general rule thick Middle Woodland sherds were considered habitation pottery and belonged to the Havana or Pike series. The thicker Havana and Pike sherds were usually less refined and appeared to be used for secular purposes (Farnsworth personal communication; Struever 1968b). The thinner finely made Middle Woodland sherds were considered ceremonial pottery belonging to Hopewell or Baehr series (Farnsworth 
personal communication; Struever 1968b). A third category of pottery was used for sherds that were moderately thick, but finely made. Staab (1984) identified the sherds as Hardin, but I redefined them and use the name "Havana Fine." I have chosen to break with her original series classification, because her definition of Hardin left the category too broad. Many of the sherds pictured and described by Staab (1984) would be categorized by my study as Hopewell or Weaver series.

Surface treatments were tabulated and placed into either the decorated or undecorated category, to assist in the deciphering the intended function of the pottery (Skibo 2012; Griffin 1952). Havana pots are considered by many to be used for culinary purposes (Braun 1977; Cantwell 1980; Farnsworth 1973; Meinkoth 1995; Morgan 1985; Morgan 1986; Struever 1968a; Struever 1968b; Wray and MacNeish 1961); however, Havana pots also occur in ceremonial contexts (Cole and Deuel 1937; Farnsworth 2004; Taylor 1929). Havana pots from ceremonial contexts tend to be highly decorated, suggesting the pots were created with a different intended function than the less well decorated Havana pots believed to be used for cooking (Cole and Deuel 1937; Farnsworth 2004; Skibo 2012; Taylor 1929). The decorated and undecorated sherds were counted and weighted and then the Ogden-Fettie assemblage was compared to other Middle Woodland sites.

The surface treatments also helped to relatively date components of Ogden-Fettie. McGregor (1952: v) explained the purpose of archaeology was "to make history out of prehistory" and this requires making a chronology. In the study of Central Illinois Valley ceramics, the chronology is difficult to understand because there are many mixed multi- 
component sites that yield confusing radiocarbon dates. Holt (2000) dated pit features and they came out as: $1820+/-60 \mathrm{BP}, 1830+/-60 \mathrm{BP}, 1480+/-60 \mathrm{BP}$. These dates are younger than expected, so the decorated pottery assemblage has been used to relatively date the site. Braun (1977) found that Naples Ovoid Stamp decoration was used during the Early Havana period, which evolved into Naples Dentate Stamps used in the classic Havana-Hopewell, and finally the late Havana and early Weaver pottery was decorated with Cordwrapped Stick Dentate (Griffin 1952). Using the relative ceramic serration I was able to make judgments about age and intensity of occupations.

Temper, like thickness, was used to supplement the typological determinations. The most common Middle Woodland temper at $\mathrm{F}^{\mathrm{v}} 196$ was grit, but sand, limestone, and shell were also present. At other Middle Woodland sites grit tempered sherds generally belong to the Havana or Hopewell series, while limestone tempered sherds belong to the Pike, Baehr, or Hopewell series (Maher 1989; Griffin 1952; Morgan 1985; Morgan 1986). However, most sherds with Baehr brushing, a characteristic of Pike and Baehr pottery, were grit temper. As such temper was used in addition to other attributes for making typological decisions.

Rim profiles are popular for ascertaining the angle of a vessels shoulder, but the application of this technique to Havana pottery from Ogden-Fettie proved unreliable, because many of the pots had beveled rims. When applied to rim sherds making up less than $10 \%$ of the orifice diameter the sherds will sit flat against a level surface, but the rim sherds with over $10 \%$ of the total orifice would not, so rim angle was abandoned. 
Orifice diameter was calculated for a few pots, but was abandoned, because most sherds provided less than $10 \%$ of the total orifice diameter and there is great potential for variations in rim shape of handmade vessels (Farnsworth personal comm.; Skibo 2012). Havana and Hopewell vessels are sometimes constructed intentionally with varying rim shape; the most common is on four lobed Middle Woodland vessels that have a roughly square orifice with rounded corners. 


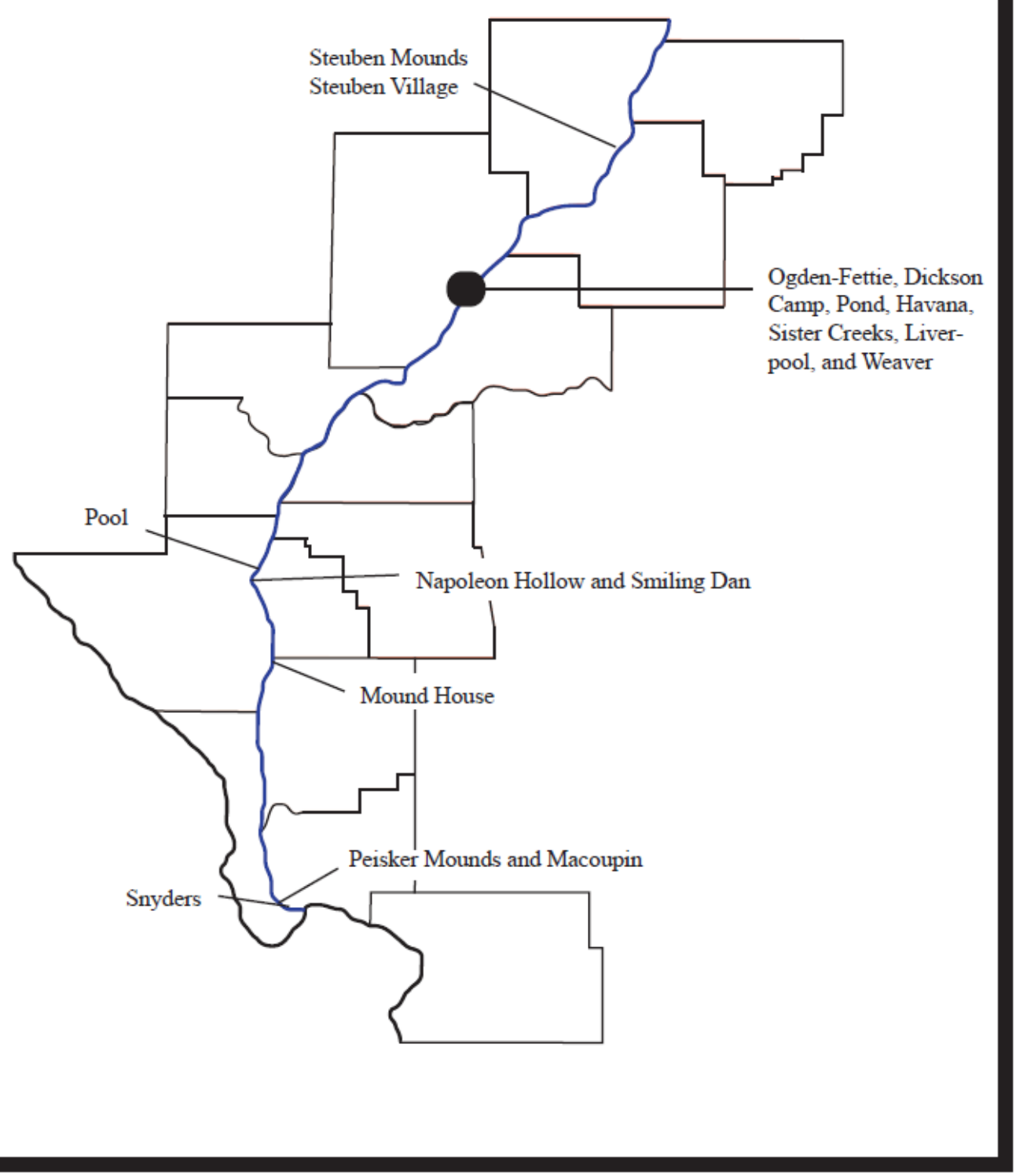

Figure 6: Illinois Valley Site Locations (Martin 2013) 


\section{Comparative Review}

Early Woodland. The Liverpool site (11-F-24), located in the Central Illinois Valley (Figure 1; Figure 6), was one of the first recognized Black Sand sites (Cole and Deuel 1937). The site was excavated as part of University of Chicago archeological survey of the Illinois River Valley. There were no house structures found at the Liverpool site but Cole and Deuel (1937) believed that the archaeological remains represented village debris (Cole and Deuel 1937). The burials at the site were simple and had little to no associated artifacts; the artifacts collected from other contexts were generally considered non-ritual objects (Cole and Deuel 1937). The pottery from Liverpool consisted of sherds belonging to Type 1 or Black Sand/Liverpool series. The pottery had surface treatments of Liverpool cordmarked and/or Black Sand Incising over cordmarking (Cole and Deuel 1937). The Early Woodland was poorly understood when Cole and Deuel (1937) was published; even today there are many questions, so I am hesitant to agree or disagree with Cole and Deuel's (1937) conclusion that Liverpool was used for habitation purposes.

Another site with a Black Sand component is Peisker, a floodplain mound group located in the Lower Illinois Valley (Figure 6). Peisker is a multi-component site that was excavated by Struever and Perino in the early 1960s (Farnsworth and Wiant 2006; Staab 1984; Struever 1968b). The Black Sand occupation at the site was located beneath Middle/Late Woodland mounds (Struever 1968b). The Black Sand occupation had no formal house structures visible, nor did it appear to have storage pits (Struever 1968b). The lack of habitation remains and poorly defined site margins, led Struever (1968b) to 
conclude that the archaeological remains represented reoccurring and short-lived Black Sand occupations. The Black Sand material consisted of high amounts of butchering and hunting tools (Struever 1968b) and the faunal remains represented a broad swath of land mammals, but was strangely lacking in deer remains (Struever 1968b). There were a few Black Sand burials that were placed in unprepared pits, and like Liverpool the burials had no associated artifacts. The lack of artifacts led to the conclusion that there was little ceremonialism surrounding the death and interment of the individuals (Struever 1968b).

The Black Sand pottery assemblage from $\mathrm{F}^{\mathrm{v}} 196$ at Ogden-Fettie was small making up only 39 total sherds, however, the pottery made up all 27 identifiable sherds collected from Mound $\mathrm{F}^{\circ} 188$. The 1931 excavations of $\mathrm{F}^{\circ} 188$ returned only 54 artifacts, most of which belonged to the same unceremonial category as the artifacts collected from the Liverpool and Peisker sites. The type of artifacts collected from $\mathrm{F}^{\circ} 188$ show the mound was Early Woodland. Mound $\mathrm{F}^{\circ} 188$ is relatively far away from the midden $\mathrm{F}^{\mathrm{v}} 196$, which could explain the low frequency of Black Sand sherds from the midden. $\mathrm{F}^{\mathrm{o}} 188$ was probably not contemporary with $\mathrm{F}^{\mathrm{v}} 196$ and suggests that one of the other midden areas from the site will have a larger Black Sand presence. There were a few sherds from $\mathrm{F}^{\mathrm{v}} 196$ that exhibited both Black Sand and Havana ceramic traits which could be the cultural link between the cultures of Black Sand, Morton, and Havana (Farnsworth and Asch 1986).

Middle Woodland Ceremonial. Struever (1968b) also mentions a Middle Woodland Havana-Hopewell midden at the Peisker site. The midden was situated next to a group of Middle Woodland mounds and was most likely contemporary with the 
mounds. The artifacts collected from Peisker were represented by a large amount of classic Hopewellian Ceremonial artifacts, such as mica, exotic cherts, and other long distance trade items (Struever 1968b). The site had a low occurrence of storage/cooking pits, which suggested that the food was not stored at the site (Struever 1968b). At Peisker there is evidence of the secular activities of pottery production, lithic production, and food preparation. The evidence of habitation activities was interpreted as the activities required to maintain the population during mound construction. All of these factors helped shape Struever's (1968b) model for a specialized mortuary camp and later a Regional Transaction Center (Struever and Houart 1972).

Peisker influenced Struever when he created his settlement model. Peisker was used as an example of a ceremonial mortuary camp, but does not adhere to the requirements of a mortuary camp (Struever 1968b; Struever and Houart 1972). Staab (1984) re-examined Peisker and she found that there was a fairly large percentage of sherds, identified as Havana by Struever (1968b), inside and under Mound 3. Most of the sherds were correctly identified as Havana, but some had a mixture of Havana and Hopewell traits. Staab (1984) created a new class of ceramics known as "Hardin Series" to accommodate the dual characteristic sherds. Staab (1984) identified Hardin vessels appearing in burial contexts. The discovery of non-Hopewell burial vessels revolutionized her ideas about site function. She surmised that Hardin series pottery appears early in Havana-Hopewell culture, then is replaced by Hopewell pottery, but reappears near the end of Havana-Hopewell (Staab 1984). Staab (1984), using the Struever and Houart's (1972) Hopewell Interaction Sphere model, argued that the Hardin 
vessels were used at the beginning and end of Havana-Hopewell culture, because there was a low supply of Hopewell vessels. Hardin Series has not been well accepted, because the definition is broad and the Havana ceremonial vessels only appear at a few Havana sites (Farnsworth personal comm.; Henriksen 1957; Staab 1984, McGregor 1952; Taylor 1929). I would have categorized some of the Hardin sherds pictured in Staab (1984) as Hopewell. I believe she categorized thick grit tempered sherds as Hardin series when they were actually Hopewell sherds, because they did not fit the traditional definition of Hopewell pottery. She also found that although Peisker was associated was a mound group, it was archaeologically indistinguishable from habitation sites. There were subsistence tools, a high proportion of Havana cooking pots, and a possible pottery production facility.

The Sister Creeks and Clear Lake mound centers are also located in a floodplain setting in the Central Illinois Valley (Figure 1; Figure 6). A large proportion of the ceramics from the mound centers was Type 2 or Havana pottery, it made up an estimated $87 \%$ of the ceramics from surface collections from Sister Creeks and $96 \%$ from Clear Lake (Cole and Deuel 1937; Fowler 1952; Meinkoth 1995). Decorated pottery dominated the ceramic collection from Sister Creeks at an estimated $62 \%$ decorated from surface collections, while plain or cordmarked sherds made up $72 \%$ of the Clear Lake ceramics (Cole and Deuel 1937; Fowler 1952). The Late Woodland Weaver ware makes up a large percentage of the pottery from Clear Lake, which suggested to Fowler (1952) that there was a complete transition at the site from Havana to Weaver. The lithics from Sister Creeks are similar to those found at $\mathrm{F}^{\mathrm{v}} 196$; the collection was comprised mostly of 
local Avon chert, with Cobden/Dongola constituting the second most abundant type (Cole and Deuel 1937, Hennessy 1988; Meinkoth 1995). Under one of mounds at Sister Creeks a large structure with a double row of posts was found (Cole and Deuel 1937). Cole and Deuel (1937) stated that the structure was probably open air and used to house bodies, because no central support posts were found and a mound was built over where the structure stood.

Napoleon Hollow is located in the Lower Illinois Valley in close proximity to the Elizabeth Mounds and just across the Illinois River from the Smiling Dan site (Figure 6) (Stafford and Sant 1985; Wiant and McGimsey 1986). The proximity to mounds and the artifacts recovered suggested Napoleon Hollow Block IV was used for ceremonial purposes. Havana sherds made up $75 \%$ of the ceramics collected from Napoleon Hollow and $34 \%$ of those sherds were decorated. The faunal assemblage at Napoleon Hollow appeared to be similar to the assemblage at Smiling Dan, but there were a few significant differences (Morgan 1985; Morgan 1986). Napoleon Hollow had a smaller number of identified species, fewer fish even though it was in close proximity to backwater lakes, and most of the deer remains present at Napoleon Hollow were leg cuts associated with high status cuts of meat. The dominance of legs showed meat was transported to the site for a special purpose (Styles and Purdue 1986; Wiant and McGimsey 1986).

The next comparative site comes from Calhoun County, Illinois which occupies the southern tip of the peninsula between the Illinois and Mississippi rivers (Figure 6). The Snyders Mound Group (11-C-8) is made up of a village area and 16 bluff crest mounds belonging to the Middle Woodland (Braun et al. 1982). The Snyders mounds 
were excavated over the years by both amateur and professional archaeologists (Braun et al. 1982). The amateur excavations were not well documented, making some information about the mounds unattainable (Braun et al. 1982). Luckily, the excavations carried out by Titterington were better documented and uncovered a Havana Zoned pot and a Knife River Chalcedony Ross Blade (Braun et al. 1982). The Knife River Chalcedony shows the people who used the Snyders Mounds were involved in long distance trade or resource procurement, as Knife River Chalcedony originates in South Dakota (Braun et al. 1982; Caldwell 1964; Conrad 2004; Struever 1964).

The Havana Mound Group located in the Central Illinois Valley Floodplain, is also known as the Neteler Mound Group (Figure 1; Figure 6). The Havana Mounds (11MN-2) are very near Ogden-Fettie, but on the opposite side of the Illinois River. The Havana Mound Group was excavated as part of a salvage mission to make way for a power plant that was to be constructed (McGregor 1952). The excavations turned up a large structure under Mound 9 (Cole and Deuel 1937; McGregor 1952). The structure was believed to have support posts which was different than the Sister Creeks structure and was therefore believed to be part of the Havana Village deposits (McGregor 1952). However, structure may have actually had a similar function to the one found at Sister Creeks, in that it was most likely used to house the dead before the construction of a mound. Other than the structure the 1929 excavations by Moorehead and Taylor uncovered Havana and Morton burial pots inside Mound 6 that were highly decorated (Fowler 1952). Havana pottery used as burial furniture at the Havana, Snyders, Peisker and other mound groups shows the division between ceremonial and secular pottery is 
not as clear as suggested by Struever's (1968b) model.

Middle Woodland Habitation. Middle Woodland habitation artifact assemblages are quite different than ceremonial sites (Cantwell 1980, Stafford and Sant 1985; Struever 1968b; Wiant and McGimsey 1986). Apple Creek (11-GE-2) had a high density of structural remains including a large number of storage pits (Struever 1968b). There was also a large amount of subsistence remains, including hunting and butchering tools (Struever 1968b). Although, Apple Creek had Hopewellian ceremonial items such as mica, cut bear teeth, and fragmentary platform pipes, the site was interpreted as a habitation site, and the ceremonial objects were believed to be broken remnants from production (Struever 1968b).

The sites of Dickson Camp and Pond sit on a bluff-top that overlooks OgdenFettie and the Central Illinois River Valley (Figure 1; Figure 6). The two sites were analyzed by Cantwell (1980), who reported 100\% of the sherds from the sites belonged to the Havana series (some could be Havana Fine). Dickson Camp had many subsistence tools, human and dog burials in pit features, and 5\% decorated Havana sherds. Although Dickson Camp was the location of human and dog burials it was interpreted as a habitation site. Decorations were seen on $16 \%$ of the Havana ceramics from the Pond site. Pond also had a high percentage of lamellar flakes (47\%), shallow pit features (most were less than $30 \mathrm{~cm}$ ), and no permanent structures. Cantwell (1980) considered these factors as an indication of a specialized work camp. The definition of Pond as a specialized work camp needs more investigation, because lamellar blades are usually associated with ritual areas. 
Smiling Dan is a bluff-base site in the Lower Illinois River Valley that is contemporary with and just across the river from Napoleon Hollow, but the site function is quite different (Figure 6) (Stafford and Sant 1985; Wiant and McGimsey 1986). The site was determined to have a habitation function based on the presence of high numbers of habitation objects. The pottery from the site was $83 \%$ Havana sherds, which can be associated with habitation or ceremonial function. But only $6 \%$ of the Havana sherds were decorated, which supports the habitation designation for the site. The faunal assemblage from the site also pointed to a habitation function, the assemblage had a high diversity in species including many fish. Deer also played a large role at Smiling Dan making up a large percentage of the faunal remains. The amount of deer remains was similar to those from Napoleon Hollow, but the Smiling Dan assemblage consisted of whole deer rather than just select cuts.

The Pool site located in the Lower Illinois River Valley (Figure 6) showed a similar ceramic assemblage to Smiling Dan, as Havana sherds dominate the Pool site making up $93 \%$ of the ceramic assemblage (Epstein 1951). Undecorated sherds constituted 94\% of the Havana ceramics (McGregor 1958; Epstein 1951), which also supports the notion that the site had a habitation function. There were also the remains of a house present, which in conjunction with the high percentage of habitation pottery which suggested to McGregor (1958) that the site had a habitation function. Weaver pottery also was present at the site, but in a much smaller percentage (McGregor 1958; Epstein 1951).

The Steuben Village (11-MA-2) is an Upper Illinois Valley site located in 
Marshall County, Illinois (Figure 6). The ceramic assemblage is similar to the Pool site, with $95 \%$ of the excavated sherds belonging to the Havana series (Morse 1963). Undecorated Havana sherds made up $86 \%$ of the total excavated Havana sherds and appear to be more prevalent at the lower levels showing a preference for undecorated vessels during the early occupation of Steuben (Morse 1963). The surface collection from Steuben contained $48 \%$ decorated Havana sherds; I considered this number to be abnormally high. There are various reasons why the number of decorated sherd could be artificially high. Steuben Punctate is often applied to entire vessels, which could inflate the number of "decorated" vessels as decoration on other vessels is often confined to the rim and shoulder. The high number of decorated sherds may also have been a result of a collection bias, because much of it was recovered by amateur collectors. Steuben Village also had the remains of a house and many pit features (Morse 1963). The site function was considered habitation because of the high amount of Havana pottery, residential structure, and large amount of pit features. The site was believed to have been occupied during the Middle to late Havana-Hopewell based on relative chronologies, mainly on the basis that there were no early Havana or Hopewellian artifacts (Morse 1963). The radiocarbon dates from Steuben show a similar time frame 2010-1375 +/- 250 BP.

The Weaver site (11-F-61) is a floodplain mound group and village site located in the Central Illinois Valley (Figure 1; Figure 6). It was occupied extensively during the Middle and Late Woodland periods (Wray and MacNeish 1961). The Weaver mounds have been tested by collectors and amateur archeologists for years, which destroyed much of the context within the mounds (Wray and MacNeish 1961). Luckily the village 
site had seen far less interest allowing for excavations in less disturbed contexts (Wray and MacNeish 1961). The location of the Weaver Village site is similar to Ogden-Fettie in that it is near floodplain mounds; however, the Weaver Village was determined to have a habitation function. The designation as a habitation site was made because excavations revealed a house structure and a large amount of pit features, from which $95 \%$ of the ceramics were Havana. The ceramics were also predominantly undecorated with $86 \%$ of the sherds being plain or cordmarked sherds (Wray and MacNeish 1961). The date from Weaver of $2300+/-250$ BP places the occupation of the site during the early Middle Woodland; however, the assemblage from the site shows the occupation was most extensive in the Late Middle Woodland and Early Late Woodland (Wray and MacNeish 1961). While the ceramic assemblage from Weaver is similar to that of habitation sites, the determination of site function at Weaver may be misguided, because Late Middle Woodland and early Middle Woodland ceremonial activities are poorly understood.

The Holding site is another Middle Woodland habitation site. It is located in the area of the Mississippi River Valley known as the American Bottom (Figure 6), near the Cahokia Mounds State Historic Site (Fortier 1989). Mississippi Valley Middle Woodland sites are usually single component, but the Holding site had multiple occupations during the Woodland period (Fortier 1989). The ceramics from the Holding site were quite different from the pottery from the Central Illinois Valley. There was a large amount of limestone tempered and brushed Pike pottery, which is rare in the Central Valley and non-existent at Ogden Fettie. The site offered up 92\% habitation pottery, and was an outlier for habitation sites with $27 \%$ of the habitation pottery being 
decorated (Maher 1989). The site is believed to have a habitation function, even though the site had a high frequency of decorated sherds, because there were cooking and storage pits, manos, plant and animal remains, and other subsistence remains (Fortier 1989).

The ceramic assemblage at Ogden-Fettie is comparable to many of the sites listed. Ogden-Fettie has a high percentage of Havana pottery, which according to Struever (1968b) should mean it's a habitation site. However, the site had a higher percentage of decorated sherds (33\%) than most of the sites determined to have a habitation function (Epstein 1951; Morse 1963; Stafford and Sant 1985; Wray and MacNeish 1961). The higher percentage of decorated sherds may indicate a different function (Braun et al. 1982; Meinkoth 1995; Struever 1968b; Wiant and McGimsey 1986). Table 1 compares the percentages of decorated Havana pottery at Ogden-Fettie with other HavanaHopewell sites. Table 1 also lists the available radiocarbon dates to understand timing of the sites.

Middle Woodland Special Purpose. The Pond site located a few hundred meters from Dickson Camp on the bluff overlooking the Ogden-Fettie mounds (Figure 1; Figure 6). It was characterized by shallow amorphous pit features, lamellar blades made of Cobden, Dongola, Burlington, and Avon chert, and a large percentage of undecorated pottery (84\%). Cantwell (1980) believed the archaeological remains represented a temporary special purpose site. She stated that the site was probably used for meat or hide cutting, because of the large number of blades and knives. A radiocarbon assay of charcoal from Pond yielded a date of $2100+/-70$ BP, Cantwell (1980) believed the site was more recent than the sister site of Dickson Camp. Ogden-Fettie and Pond have 
similar archaeological remains, but Pond has a much lower number of decorated sherds.

\begin{tabular}{|c|c|c|c|}
\hline Site & $\begin{array}{l}\text { Percent Havana/ } \\
\text { Percent of Decorated } \\
\text { Havana Sherds }\end{array}$ & Location & MW Dates BP \\
\hline Ogden-Fettie & $\begin{array}{l}\text { Havana- } 89.5 \% \\
\text { Decorated- } 33 \%\end{array}$ & $\begin{array}{l}\text { Central Illinois } \\
\text { Valley, } \\
\text { Floodplain }\end{array}$ & $\begin{array}{l}1830+/-60 \\
1820+/-60 \\
1480+/-60 \\
\text { (Holt 2000) }\end{array}$ \\
\hline $\begin{array}{l}\text { Dickson Camp- } \\
\text { Habitation }\end{array}$ & $\begin{array}{l}\text { Havana- } 100 \% \\
\text { Decorated- } 5 \%\end{array}$ & $\begin{array}{l}\text { Central Illinois } \\
\text { Valley, } \\
\text { Floodplain }\end{array}$ & $\begin{array}{l}1640+/-90 \\
2040+/-90 \\
\text { (Cantwell 1980; } \\
\text { Chao-li et al. } \\
\text { 1992) }\end{array}$ \\
\hline $\begin{array}{l}\text { Pond- } \\
\text { Special Purpose/ } \\
\text { Resource Gathering }\end{array}$ & $\begin{array}{l}\text { Havana- } 100 \% \\
\text { Decorated- } 16 \%\end{array}$ & $\begin{array}{l}\text { Central Illinois } \\
\text { Valley, } \\
\text { Floodplain }\end{array}$ & $\begin{array}{l}2100+/-70 \\
\text { (Chao-li et al. } \\
1992 \text { ) }\end{array}$ \\
\hline $\begin{array}{l}\text { Weaver Village- } \\
\text { House Structure- } \\
\text { Habitation }\end{array}$ & $\begin{array}{l}\text { Havana-95\% } \\
\text { Decorated- } 14 \%\end{array}$ & $\begin{array}{l}\text { Central Illinois } \\
\text { Valley, } \\
\text { Floodplain }\end{array}$ & $\begin{array}{l}2300+/-250 \\
\text { (Crane 1956) }\end{array}$ \\
\hline $\begin{array}{l}\text { Pool Village- } \\
\text { Habitation }\end{array}$ & $\begin{array}{l}\text { Havana- 93\% } \\
\text { Decorated- } 6 \%\end{array}$ & $\begin{array}{l}\text { Lower Illinois } \\
\text { Valley, Tributary }\end{array}$ & $\begin{array}{l}\text { None (Dates } \\
\text { Deemed } \\
\text { Unacceptable) }\end{array}$ \\
\hline $\begin{array}{l}\text { Steuben Village } \\
\text { Excavation- } \\
\text { Habitation }\end{array}$ & $\begin{array}{l}\text { Havana- } 95 \% \\
\text { Decorated- } 14 \%\end{array}$ & $\begin{array}{l}\text { Upper Illinois } \\
\text { Valley, } \\
\text { Floodplain }\end{array}$ & $\begin{array}{l}1375-2010+/- \\
250 \\
\text { (Crane and } \\
\text { Griffin 1958; } \\
\text { Morse 1963) }\end{array}$ \\
\hline $\begin{array}{l}\text { Steuben Surface } \\
\text { Collection- } \\
\text { Habitation }\end{array}$ & $\begin{array}{l}\text { Havana- } 92 \% \\
\quad \text { Decorated- } 48 \%\end{array}$ & $\begin{array}{l}\text { Upper Illinois } \\
\text { Valley, } \\
\text { Floodplain }\end{array}$ & $\begin{array}{l}1375-2010+/- \\
250 \\
\text { (Crane and } \\
\text { Griffin 1958; } \\
\text { Morse 1963) }\end{array}$ \\
\hline $\begin{array}{l}\text { Steuben Mounds- } \\
\text { Ceremonial }\end{array}$ & $\begin{array}{l}\text { Complete Vessels } \\
\text { Havana- } 1 \\
\text { Havana Fine- } 1 \\
\text { Hopewell- } 2 \\
\text { Baehr- } 1\end{array}$ & $\begin{array}{l}\text { Upper Illinois } \\
\text { Valley, bluff-top }\end{array}$ & $\begin{array}{l}1650-1660+/- \\
250 \\
\text { (Griffin 1958) }\end{array}$ \\
\hline $\begin{array}{l}\text { Sister Creeks } \\
\text { Surface Collection- } \\
\text { Ceremonial }\end{array}$ & $\begin{array}{l}\text { Havana- } 87 \% * \\
\text { Decorated- } 62 \% *\end{array}$ & $\begin{array}{l}\text { Central Illinois } \\
\text { Valley, } \\
\text { Floodplain }\end{array}$ & None \\
\hline
\end{tabular}




\begin{tabular}{|c|c|c|c|}
\hline $\begin{array}{l}\text { Sister Creeks } \\
\text { Mound } 61 \text { and } 62- \\
\text { Ceremonial }\end{array}$ & $\begin{array}{l}\text { Havana-** } \\
\text { Decorated- } 15 \% * *\end{array}$ & $\begin{array}{l}\text { Central Illinois } \\
\text { Valley, } \\
\text { Floodplain }\end{array}$ & None \\
\hline $\begin{array}{l}\text { Clear Lake- } \\
\text { Ceremonial }\end{array}$ & $\begin{array}{l}\text { Havana-96\% } \\
\text { Decorated- } 28 \%\end{array}$ & $\begin{array}{l}\text { Central Illinois } \\
\text { Valley, } \\
\text { Floodplain }\end{array}$ & None \\
\hline $\begin{array}{l}\text { Smiling Dan } \\
\text { (Random Squares)- } \\
\text { Habitation }\end{array}$ & $\begin{array}{l}\text { Havana- } 83 \% \\
\text { Decorated- } 6 \%\end{array}$ & $\begin{array}{l}\text { Lower Illinois } \\
\text { Valley, bluff- } \\
\text { base }\end{array}$ & $\begin{array}{l}1710-2060+/-75 \\
\text { (Safford and } \\
\text { Sant 1985) }\end{array}$ \\
\hline $\begin{array}{l}\text { Napoleon Hollow } \\
\text { Block I \& IV- } \\
\text { Ceremonial }\end{array}$ & $\begin{array}{l}\text { Havana- } 75 \% \\
\text { Decorated- } 34 \%\end{array}$ & $\begin{array}{l}\text { Lower Illinois } \\
\text { Valley, bluff- } \\
\text { edge }\end{array}$ & $\begin{array}{l}1800-2000+/-70 \\
\text { (Wiant and } \\
\text { McGimsey } \\
1986 \text { ) }\end{array}$ \\
\hline $\begin{array}{l}\text { Mound House- } \\
\text { Ceremonial }\end{array}$ & $\begin{array}{l}\text { Havana- Unsorted } \\
\text { Decorated- }\end{array}$ & $\begin{array}{l}\text { Lower Illinois } \\
\text { Valley, } \\
\text { Floodplain }\end{array}$ & $\begin{array}{l}1800-2060+/-70 \\
\text { (Buikstra et al. } \\
\text { 1998) }\end{array}$ \\
\hline $\begin{array}{l}\text { Havana Mounds } \\
\text { (Neteler Mounds)- } \\
\text { Ceremonial }\end{array}$ & $\begin{array}{l}\text { Havana } \approx 95 \% * * * \\
\text { Decorated } \approx \\
20 \% * * *\end{array}$ & $\begin{array}{l}\text { Central Illinois } \\
\text { Valley, bluff-top } \\
\text { (Sand Ridge) }\end{array}$ & $\begin{array}{l}2200-2336+/- \\
250 \\
\text { (Griffin 1959) }\end{array}$ \\
\hline $\begin{array}{l}\text { Peisker Mounds- } \\
\text { Habitation/Ceremoni } \\
\text { al }\end{array}$ & $\begin{array}{l}\text { Havana- } 67 \% * \\
\text { Decorated- } 27 \% * \\
\text { Hardin- } 18 \% \\
\text { Decorated- } 97 \%\end{array}$ & $\begin{array}{l}\text { Lower Illinois } \\
\text { Valley, } \\
\text { Floodplain }\end{array}$ & $\begin{array}{l}1700+/-120 \\
\text { (Crane and } \\
\text { Griffin 1968) } \\
2180+/-130 \\
\text { (Crane and } \\
\text { Griffin 1966) }\end{array}$ \\
\hline Massey- Habitation & $\begin{array}{c}\text { Crab Orchard-76\% } \\
\text { Decorated- } 0 \%\end{array}$ & Tributary Valley & $\begin{array}{l}1750-1930+/-70 \\
\text { (Farnsworth and } \\
\text { Koski 1985) }\end{array}$ \\
\hline Archie- Habitation & $\begin{array}{c}\text { Crab Orchard-94\% } \\
\text { Decorated- } 0 \%\end{array}$ & Tributary Valley & $\begin{array}{l}1800-1900+/-70 \\
\text { (Farnsworth and } \\
\text { Koski 1985) }\end{array}$ \\
\hline Holding- Habitation & $\begin{array}{r}\text { Havana/Pike- } 92 \% \\
\text { Decorated- } 27 \%\end{array}$ & $\begin{array}{l}\text { Mississippi } \\
\text { Valley }\end{array}$ & $\begin{array}{l}\text { 1790-2010+/-80 } \\
\text { (Fortier 1989) }\end{array}$ \\
\hline
\end{tabular}

Table 1. Percentage of Decorated Havana Pottery by Site

* Only Rimsherds

** Not separated into Wares, could include Hopewell sherds

*** Estimates from McGregor (1952) 


\section{CHAPTER IV \\ OGDEN-FETTIE ARTIFACT ANALYSIS}

The results in this chapter are broken down into sections based upon artifact type and area of investigation. The first part of the analysis looks at the ceramic collections from Ogden-Fettie $\mathrm{F}^{\mathrm{v}} 196$, which were analyzed and separated into series based upon the proposed function: habitation or ceremonial. The Havana and Pike series vessels made up the habitation category, while Hopewell, Baehr, and Havana Fine pots comprised the ceremonial category. These data were then applied to the model presented in Struever (1968b), which claimed that sites with high percentages of Havana pottery had a habitation function.

The ceramic analysis from $\mathrm{F}^{\mathrm{v}} 196$ revealed that $89.5 \%$ of the pottery is Havana, placing it firmly in the habitation category according to the Struever (1968b) model. However, my analysis suggests that the model was inappropriate for determining the site function of Ogden-Fettie. To account for the inaccuracies in the model, the amount of decorated Havana sherds was calculated. Known ritual sites have returned high percentages of decorated Havana pottery and Havana burial usually are highly decorated, thus high percentages of decorated sherds suggests an increased ceremonialism (Griffin et al. 1970; Wiant and McGimsey 1986). The 33\% decorated Havana sherds from $\mathrm{F}^{\mathrm{v}} 196$ suggested the site had increased ceremonialism (Wiant and McGimsey 1986). During the 
analysis all decorations on a sherd were recorded. The decorated sherds included many sherds with two or more decorations, so all results are presented as number of sherds where the decoration appears and as a percentage of total decorated sherds. The most common pair was Naples Dentate Stamping and Havana Zoning. I chose to count all decorations appearing on a sherd, because it is impossible to determine the prevalence of a decoration without whole pots.

Then all the ceramics and some selected artifacts from the excavations of $\mathrm{F}^{\circ} 188$ and $\mathrm{F}^{\circ} 191$ are presented in conjunction with the non-Middle Woodland ceramics from $\mathrm{F}^{\mathrm{v}} 196$. This part of the chapter was used to understand the context in which $\mathrm{F}^{\mathrm{v}} 196$ was created. Looking at the non-Middle Woodland ceramics from $\mathrm{F}^{\mathrm{v}} 196$ it is believed that $\mathrm{F}^{\mathrm{o}} 191$ may have been contemporary with the midden $\mathrm{F}^{\mathrm{v}} 196$, while $\mathrm{F}^{\mathrm{o}} 188$ was created prior to the midden.

The final section includes some lithic material from $\mathrm{F}^{\mathrm{v}} 196$ to give further context to the site and to understand if the lithic material agreed with Struever (1968b) or if the revised Struever and Houart (1972) model was any more accurate when applied to $\mathrm{F}^{\mathrm{v}} 196$. Both are shown to have flaws when applied to $\mathrm{F}^{\mathrm{v}} 196$, so I have revised the model and added an "Aggregation Site," which is identified by decorated Havana sherds.

\section{Middle Woodland Pottery}

In 1959 Struever and Wettersten conducted a surface collection and excavation of Ogden-Fettie. The surface collection was lumped together, in Wettersten (1960), as one unit and no distinction was made between rim and body sherds, because there was no provenience. In 1959 Struever and Wettersten reported collecting 2285 sherds, but 
Wettersten only analyzed 2235, because 50 of the sherds were Mississippian (Sheilds n.d., Wettersten 1960). Wettersten found that 2035 (91\%) were from the Middle Woodland Period, 2000 (98\%) of those sherds were Havana Series and 35 (2\%) were Hopewell Series (Wettersten 1960). It is not clear whether the sherd totals reported in Wettersten (1960) are from surface collections or more likely a combination of surface collections and excavations. In my analysis I was only able to locate a total of 944 Middle Woodland sherds from the 1959 archaeological investigations, 788 from surface collections and 156 from excavations. The discrepancy in sherd totals is substantial and may be caused by misplaced artifacts or disposal of sherds.

1959 Struever and Wettersten Surface Collection. My analysis of the 788 surface collected rim and body sherds was comparable to Wettersten (1960), as I found that 716 (91\%) of the sherds were Havana sherds from the habitation category. There were 72 (9\%) ceremonial category sherds made up of 36 (4.5\%) Hopewell and 36 (4.5\%) Havana Fine ware (Figure 7). There was one Morton sherd that I included in the Havana Fine category because it had many Havana Fine attributes; also 10 sherds tempered with shell and exhibiting Middle Woodland decorations were included in the Havana Fine category. The 10 shell tempered sherds appear to have come from one or two finely crafted vessels. 


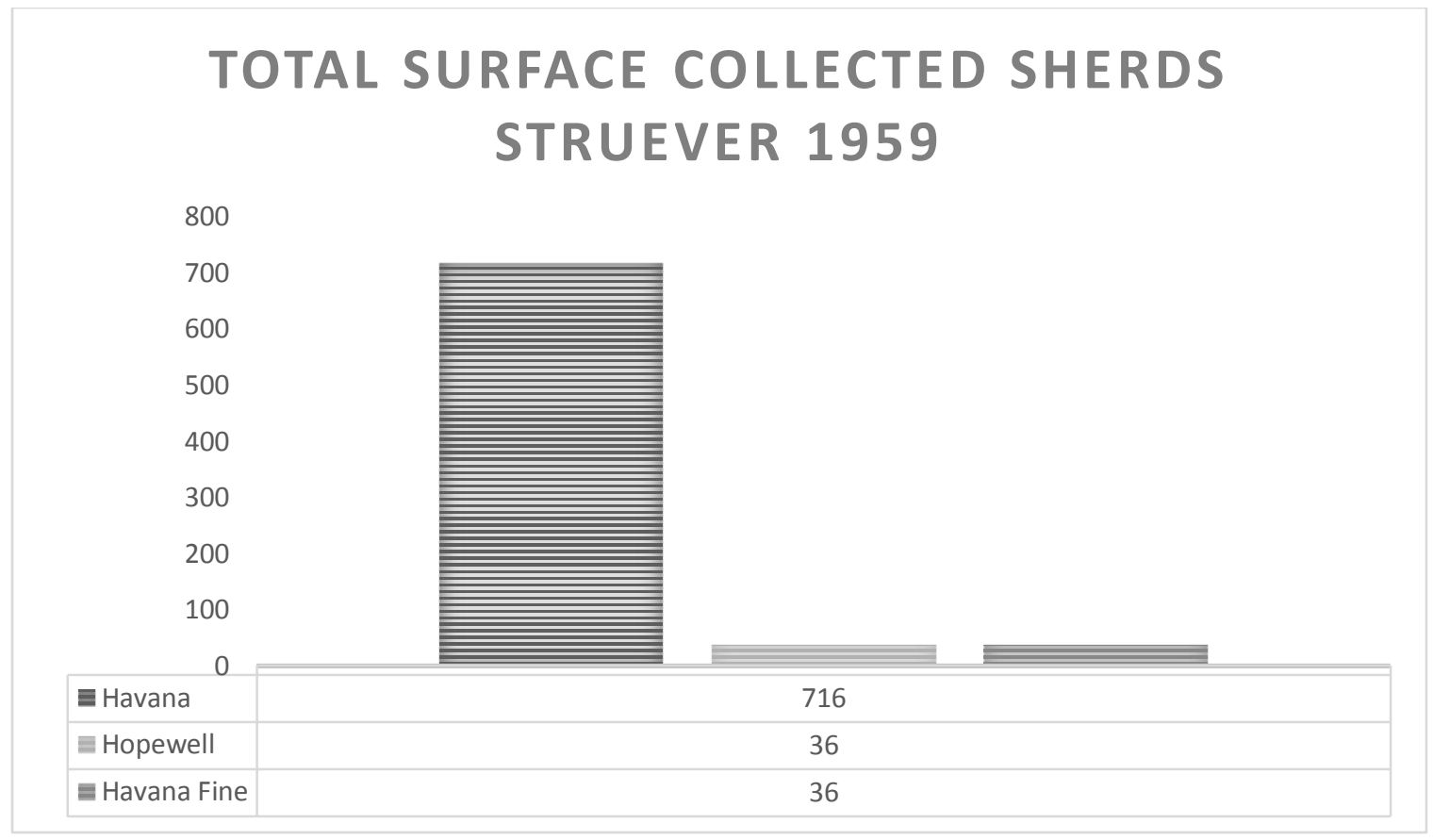

Figure 7: Total Surface Collected Sherds Struever 1959.

Of the Havana sherds a total of $258(35 \%)$ were decorated with a surface treatment other than smoothing, cordmarking, smoothed-over cordmarking, brushing, or nodes. The percentage of decorated sherds may indicate the sherds were used for ritual gatherings, because the pots were chosen to be decorated. The decorated sherds were dominated by the 184 Naples Dentate sherds, which constituted $71 \%$ of the total number of decorated sherds from the surface collection. A high number of Naples Dentate sherds points to $\mathrm{F}^{\mathrm{v}} 196$ being used most extensively during the classic Havana-Hopewell period (Braun 1977). There were a total of 36 sherds with Havana Zoned decorations constituting $14 \%$ of the decorated collection. The early Havana decorations appeared on $15 \%$ of the surface collected sherds, with a total of 38 sherds. The lower number of early Havana decorations points to the midden not being used heavily during the initial days of 
the Havana culture or potentially a quick transition from early Havana culture to the classic Havana culture. My analysis showed slightly different percentages with $91 \%$ of the sherds being from the Havana series, while Wettersten (1960) found 98\% to be Havana sherds. The discrepancy probably resulted from my use of an updated typology (Appendix A) or as a result of the missing sherds.

1959 Struever and Wettersten Excavation. In 1959 Struever and Wettersten excavated five test squares measuring five foot by five foot (TT\#1-TT\#4 and TT\#6) and one 30 foot trench (TT\#5), to attempt to understand the function of Ogden-Fettie $\mathrm{F}^{\mathrm{v}} 196$. They collected 156 Middle Woodland sherds during their 1959 excavations. There were 147 (94\%) Havana Series and 34 (23\%) of those sherds were decorated. Nine (6\%) Havana Fine Series and no Hopewell Series sherds collected (Figure 8).

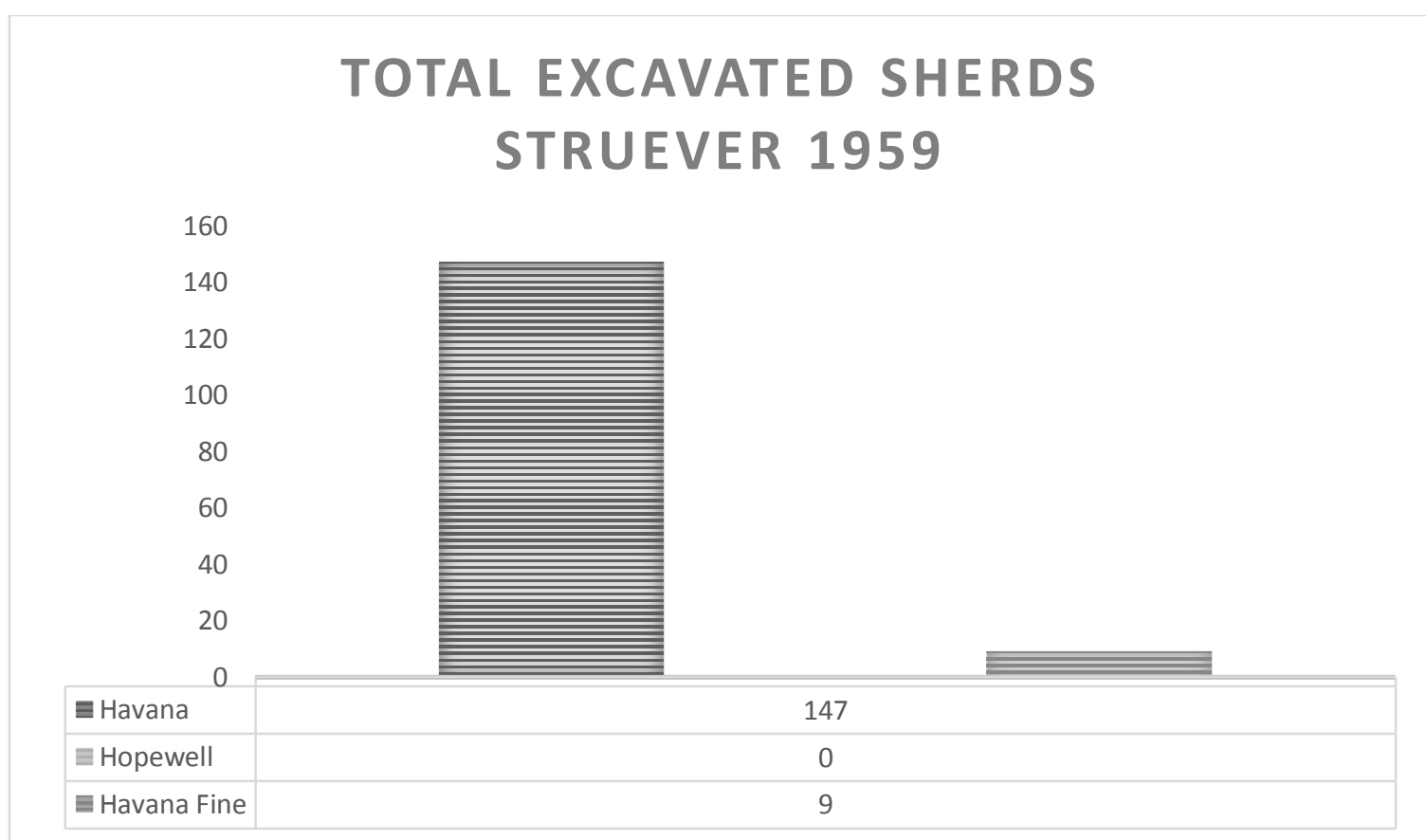

Figure 8: Total Excavated Sherds Struever 1959. 
Units TT\#1, TT\#3, T\#5, and TT\#6 yielded a total of 156 pottery sherds. I only discuss TT\#1 on its own because it yielded by far the most sherds (105), but the data from the other units is available in (Appendix B). Only two levels were excavated in TT\#1 the 6"12 " level which had 42 sherds and the 12"-18" level which had 63 sherds. The 6"-12" level consisted of $100 \%$ Havana sherds; 10 (24\%) were decorated Havana sherds, four of which were decorated with Naples Dentate and six sherds were burnished. If the burnished sherds are not considered decorated the total percent of decorated sherds drops to $9.5 \%$. A total of 20 sherds were smoothed-over cordmarked and 12 sherds were completely smoothed. The high number of smoothed-over cordmarked sherds also suggests a later date, because the Central Illinois Valley Havana tradition shows a strong preference for smoothing.

The 12"-18" level of TT\#1 contained 63 total sherds, of which 59 or $94 \%$ were habitation sherds; from the Havana series, the other four $(6 \%)$ were the ceremonial Havana Fine sherds. There were seven (12\%) burnished sherds, three (5\%) Naples Dentate sherds, and one (2\%) Morton Incised sherd. The four Havana Fine sherds were burnished and tempered with a mixture of shell and grit. The undecorated Havana sherds were predominantly smoothed with a total of 29 , smoothed over cordmarked sherds made up 12 of the total, finally there were seven cordmarked sherds. This level is more indicative of the classic Havana-Hopewell period, and it may represent a time when Havana pottery was used in both a secular and ceremonial setting. 
1961 DeBusk Surface Collection. In 1961 a surface collection of $\mathrm{F}^{\mathrm{v}} 196$ was conducted by DeBusk. There were a total of 80 sherds, weighing $1313.8 \mathrm{~g}$, in the collection (Figure 9). Havana series made up $92 \%$ of the total with 73 sherds, there were three (4\%) Hopewell sherds, two (3\%) Havana Fine sherds, and one (1\%) Mississippian sherd (Appendix B). There were only 18 decorated Havana sherds making up $24 \%$ of the total Havana sherds and the Naples variety of decorations was the most common at $66 \%$, while $39 \%$ of the sherds had Havana Zoning. Included in the 73 Havana sherds was one limestone tempered Havana sherd and one grit tempered Havana-Pike sherd exhibiting Baehr brushing. There was also one early Havana sherd decorated with a variation of Naples Ovoid Stamping. One of the two Havana Fine sherds was shell tempered and burnished. The collection was so small that I felt it unreliable to make judgments about what was found. 


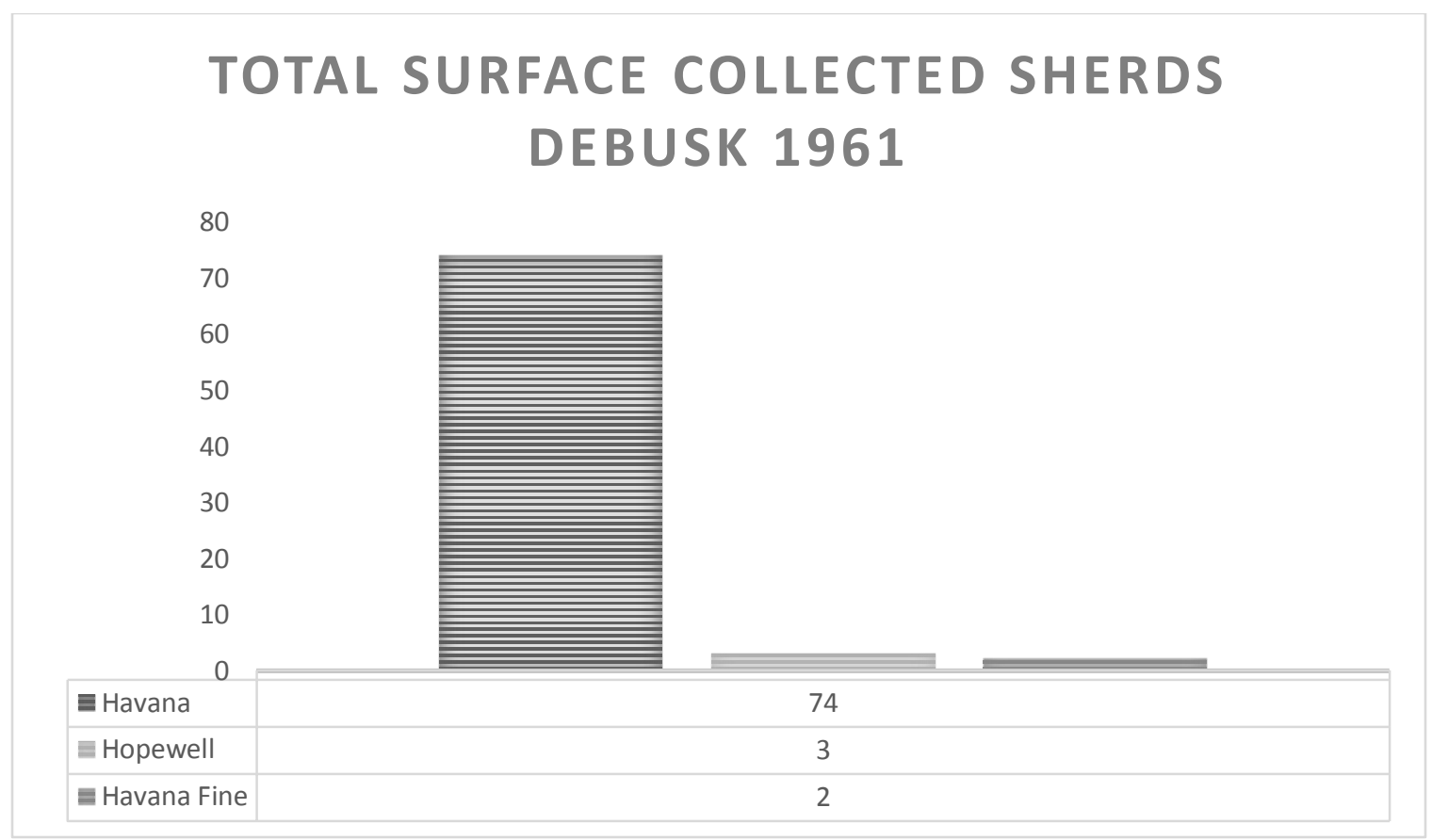

Figure 9: Total Surface Collected Sherds DeBusk 1961.

1985 NYU Excavations. In 1985 the New York University field school under the direction of Howard Winters excavated 18 one meter by one meter test squares in the midden $\mathrm{F}^{\mathrm{v}} 196$ at Ogden-Fettie (Figure 10; Table 1). This analysis found that all of the units produced some pottery and the combined units produced 755 Middle Woodland sherds in total. My analysis determined there were 679 (90\%) Havana series sherds, 62 (8\%) Hopewell or Baehr series sherds, and 14 (2\%) Havana Fine sherds (Table 2; Figure 11). A total of 18 Havana sherds were delaminated making surface treatment identification impossible. There were 196 (29\%) decorated Havana sherds, and 467 (71\%) undecorated Havana sherds. There were six features returning pottery, Features 4, 
$5,6,9,10$, and 12. A total of 55 rim and body sherds were removed from the six features (Figure 12).

The 18 NYU field school units were excavated and analyzed in four unit blocks (Figure 10). Block I made up of units 849N209E, 849N210E, 850N209E, and $850 \mathrm{~N} 210 \mathrm{E}$. Block II consisting of units 850N217E, 850N218E, 850N219E, 850N220E, $851 \mathrm{~N} 217 \mathrm{E}, 851 \mathrm{~N} 218 \mathrm{E}$, and $851 \mathrm{~N} 219 \mathrm{E}$. The units that make up Block III were 849N230E, 849N231E, 850N230E, 850N231E. Finally, Block VI comprised of units $834 \mathrm{~N} 230 \mathrm{E}$ and $835 \mathrm{~N} 230 \mathrm{E}$ (Figure 10). The results from the excavations are presented and discussed in blocks, because the blocks of units appear to show differences in dated pottery. 


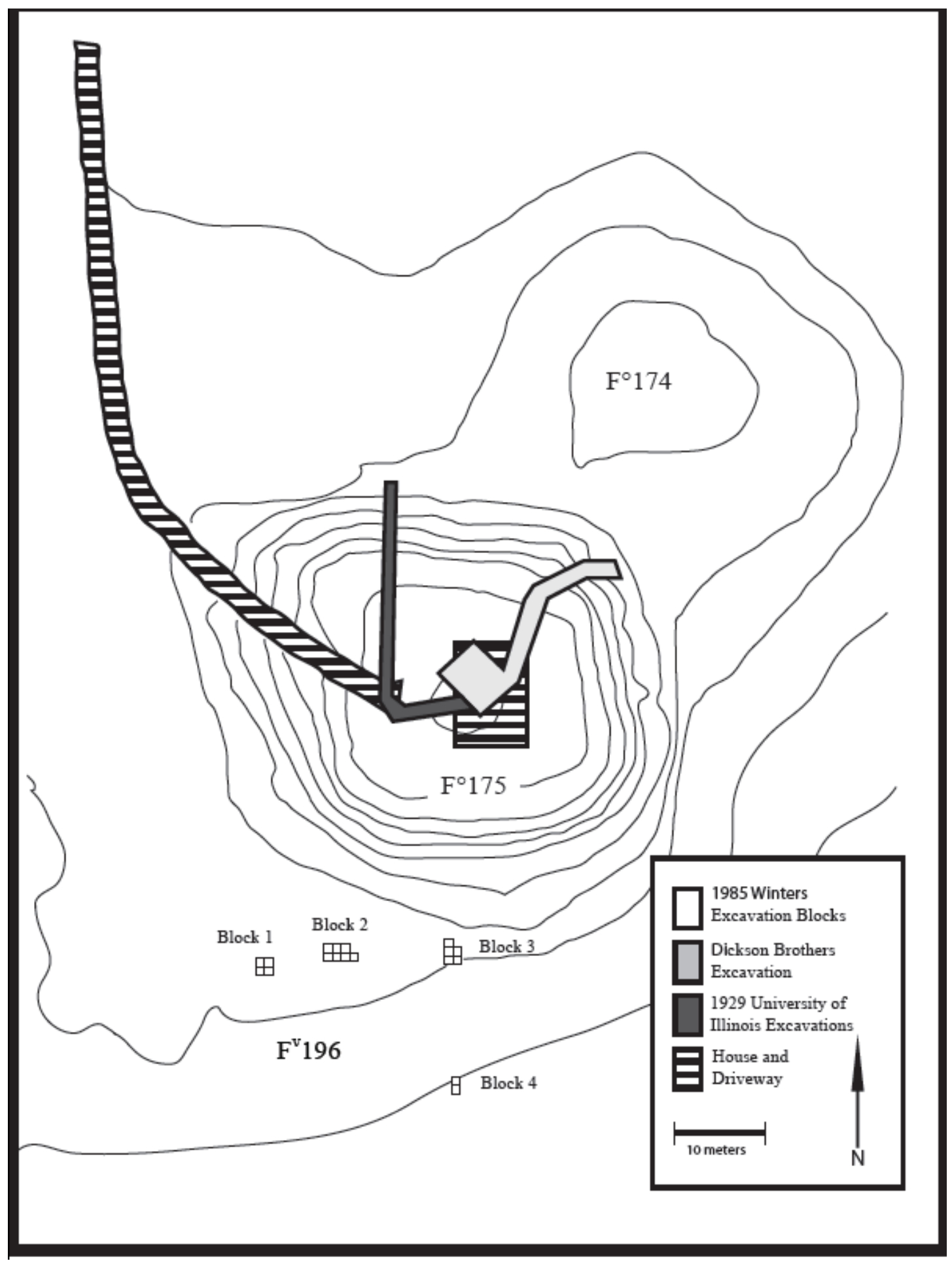

Figure 10: Topographic Map Showing Previous Excavations of Ogden-Fettie (Collection of Illinois State Museum; Sheilds n.d.). 
Block I had a total of 75 sherds weighing $571.9 \mathrm{~g}$, the sherds from Block II weighed 1976.3g and totaled 290, the 181 sherds from Block III weighed 1298.3g, and Block IV had 212 sherds weighing 1739.7g (Table 2).

\begin{tabular}{|c|c|c|c|c|}
\hline & Block I & Block II & Block III & Block IV \\
\hline Sherd Total & 75 & $290 *$ & $181^{*}$ & $212 *$ \\
\hline Havana Series & $62(82.5 \%)$ & $256 *(88.5 \%)$ & $160 *(88 \%)$ & $201 *(94.5 \%)$ \\
\hline Havana Decorated & $34(55 \%)$ & $62(24 \%)$ & $68(42.5 \%)$ & $32(16 \%)$ \\
\hline $\begin{array}{l}\text { Hopewell/Baehr } \\
\text { Series }\end{array}$ & $11(15 \%)$ & $32(11 \%)$ & $16(9 \%)$ & $\begin{array}{ll}6 & (3 \%)\end{array}$ \\
\hline Havana Fine Series & $2(2.5 \%)$ & $2 \quad(0.5 \%)$ & $5 \quad(3 \%)$ & $5 \quad(2.5 \%)$ \\
\hline
\end{tabular}

Table 2: Sherd Totals from 1985 Excavation Blocks

*Sherd total contains delaminated sherds

Block I and Block III both have a high percentage of decorated sherds similar to many of the other Middle Woodland floodplain mound groups, while Blocks II and IV stood out for having a low percentage of decorated Havana sherds. Block II and Block IV had high amount of Baehr Brushed sherds, which was a surface treatment used during the late Havana-Hopewell culture. Blocks I and III were located on the edges of $\mathrm{F}^{\mathrm{v}} 196$ appeared to be used earlier than Blocks II and IV. All of the blocks had a low amount of sherds believed to belong to the early Havana tradition, 17 sherds or $2.5 \%$ of the total. 
The early Havana sherd total was low, showing $\mathrm{F}^{\mathrm{v}} 196$ was probably occupied after most of the mounds had been built.

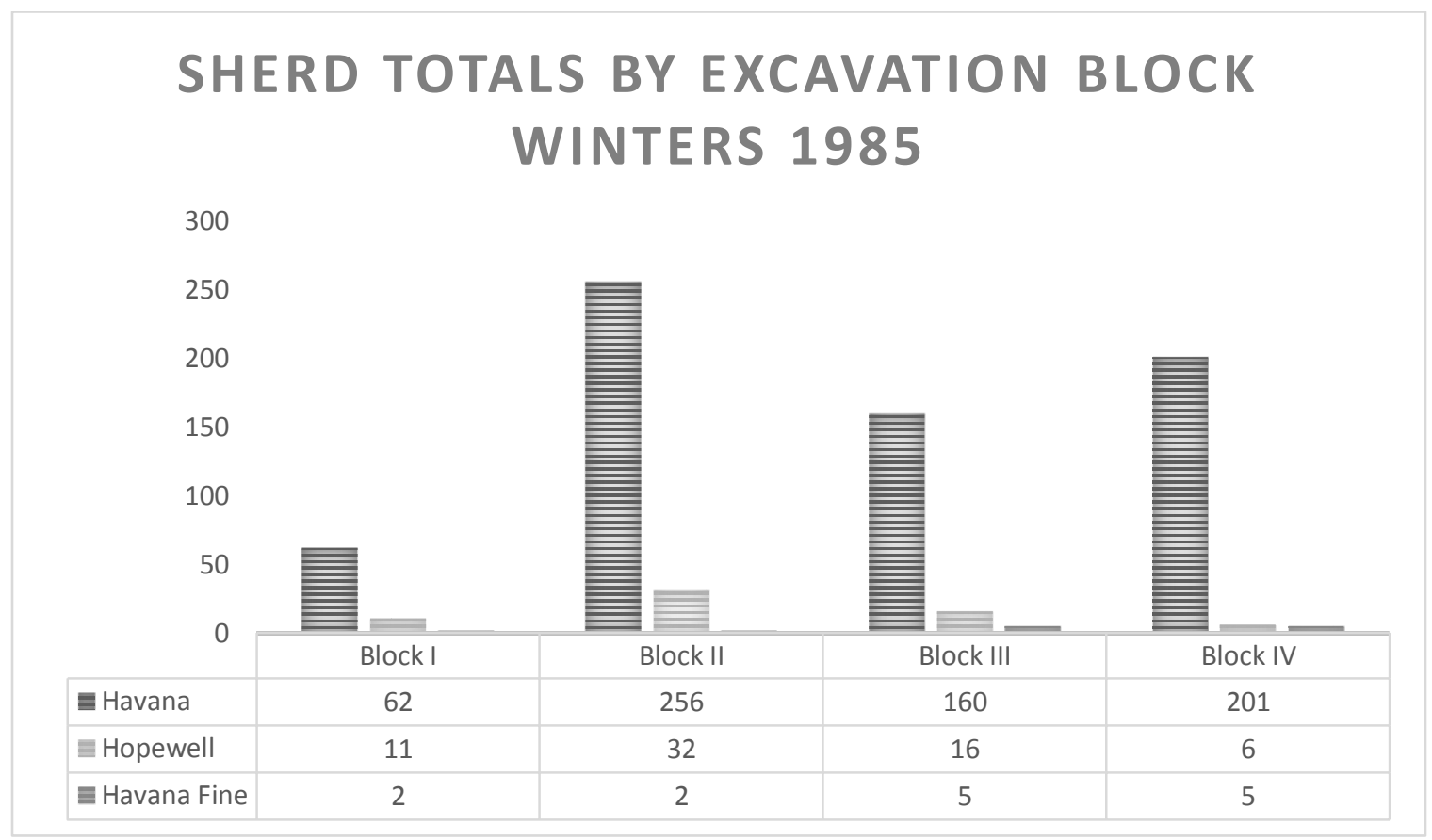

Figure 11: Sherd Totals by Excavation Block Winters 1985.

Naples Dentate again made up the largest proportion of the decorated sherds collected during the 1985 field season with a total of 93 (47.5\%) (Appendix C). The second most abundant decoration group was the Havana Zoned or Incised at 24 (12\%) sherds. The two decorations show that $\mathrm{F}^{\mathrm{v}} 196$ was probably used most heavily after the early Havana time period.

There were six features (Feature 4, 5, 6, 9, 10, and 12) excavated by the NYU field school. A total of 55 sherds were collected from the six features. There were a total of 11 Havana and type-indeterminate sherds collected from the group of Features 4, 9, 10 
and 12. There were four sherds decorated with Naples Dentate stamping and the remaining sherds were undecorated, consisting of four smoothed sherds, two smoothedover cordmarked sherds, and one incised type-indeterminate sherd. Feature 5 yielded a total of 25 sherds that were either Havana series or type-indeterminate, three of the sherds were decorated with Naples variety of decorations, two of the sherds were decorated with Naples Ovoid Stamping. The 22 undecorated sherds include eight smoothed sherds, four cordmarked sherds, three smoothed over rim sherds with flattened nodes, and seven unidentifiable sherds. There were 25 sherds collected from Feature 6 and 15 Havana sherds, eight type-indeterminate, and two were Hopewell series. The decorated sherds from Feature 6 totaled four sherds, three Naples Dentate and one early Havana decoration of Neteler Crescent. A total of six of the sherds were smoothed and five sherds exhibited cordmarking. Both Features 5 and 6 were possibly used during the early Havana period, because of the presence of early Havana decorations. They also show a preference for smoothed body sherds which is indicative of the early and middle Havana culture in the Central Illinois Valley. 


\section{TOTAL EXCAVATED SHERDS \\ FROM ALL FEATURES \\ WINTERS 1985}

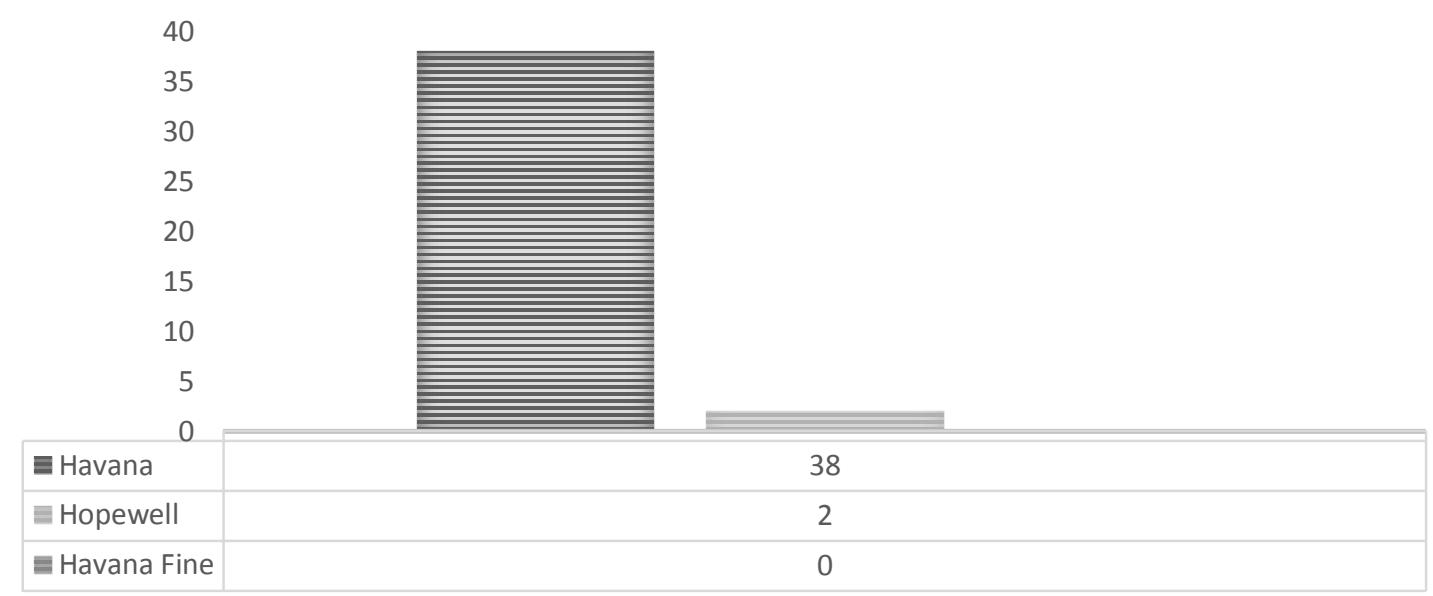

Figure 12: Total Excavated Sherds from All Features Winters 1985.

The rim sherds collected during the 1985 excavations were tabulated separately from the body sherds, because rim sherds are usually highly decorated. Rim sherd decorations are usually applied in a zone near the rim of Middle Woodland pots. A total of 98 identifiable rim sherds weighing $1541.4 \mathrm{~g}$ were tabulated, 69 of the sherds were Havana series which was $70 \%$ of the total rim sherd collection. The Havana rim sherds were all decorated except for three or $3.5 \%$ of the sherds, which had no interior or exterior decorations, all three sherds were smoothed. There were 19 or $20 \%$ Hopewell rim sherds, and 10 Havana Fine sherds making up 10\% of the total (Figure 13). There were two Brangenburg rims included in the Hopewell total. One of the Havana Fine rim sherds was decorated with Nodes and Naples Dentate stamping and was shell tempered. There were five sherds that bordered on the Havana Fine category, but they were 
tempered with sand and were undecorated making them more characteristic of Weaver sherds.

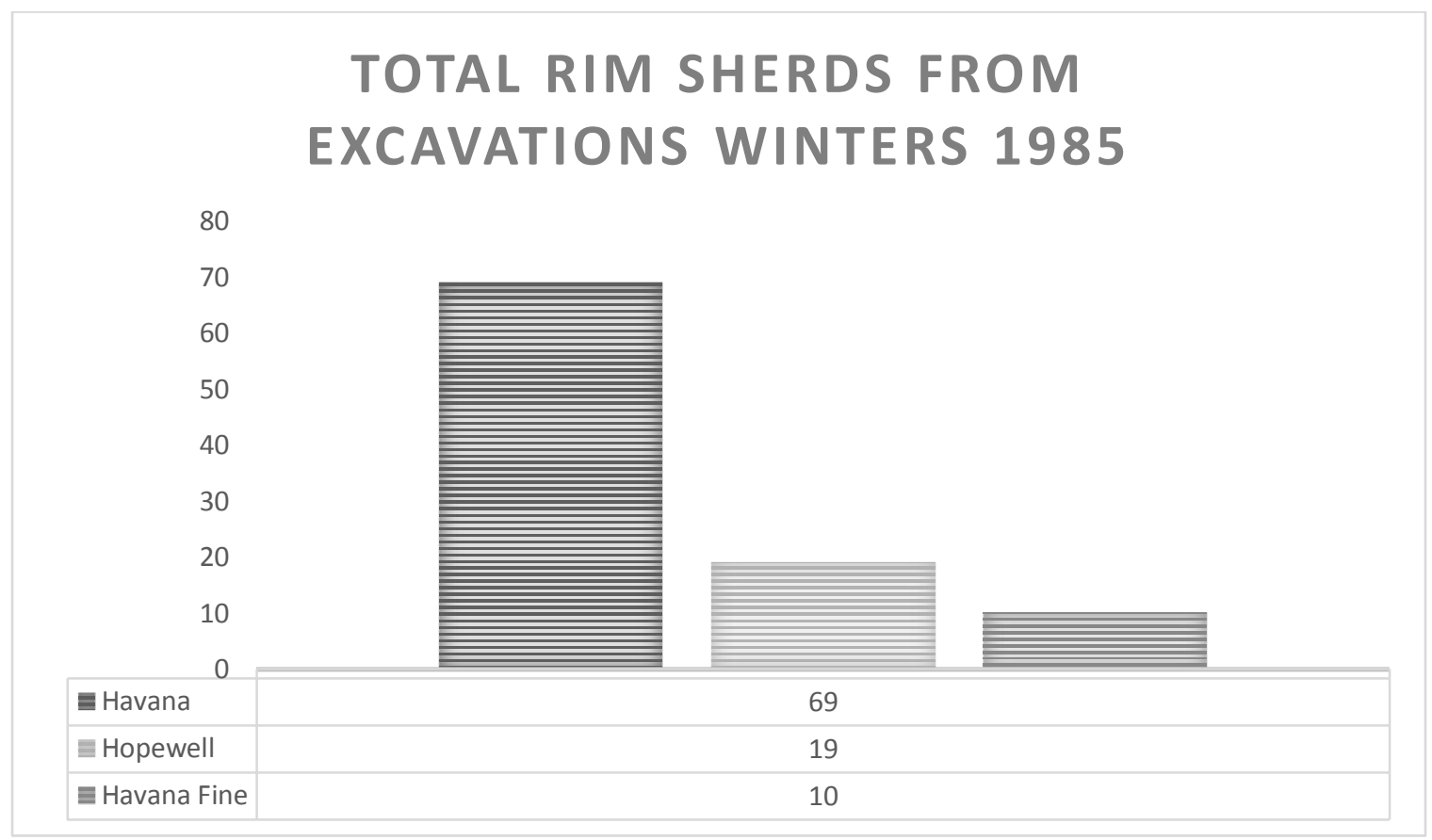

Figure 13: Total Rim Sherds from Excavations Winters 1985.

The most common Havana rim sherd decoration was Naples Dentate appearing on $49 \%$ of the rim sherds, Havana Zoned was the next most abundant group at $8 \%$ of the total. Naples variety of decoration was also the most common decoration on Havana Fine sherds at $80 \%$ of the total decorations. The early Havana decorations were rare, only two rim sherds or $2 \%$ of the total exhibited early Havana decorations (Appendix C). The prevalence of Naples Dentate on Havana Fine sherds shows that the use of ceremonial Havana pottery continued after the early Havana decorations fell out of favor. 
Compiled $F^{v} 196$ Ceramics. The total amount of Middle Woodland pottery collected from Ogden-Fettie $\mathrm{F}^{\mathrm{v}} 196$ was 1,876 sherds (Figure 14). Havana series constituted $89.5 \%$ of the total Middle Woodland ceramic collection at 1685 sherds and $554(33 \%)$ of the Havana sherds exhibited decorations. The Hopewell assemblage was relatively small at 120 sherds or $6.5 \%$ of the total pottery collection. The Havana Fine series was represented by $71(4 \%)$ sherds and 21 of them were shell tempered sherds, from three or more vessels. The percentages in the ceramic collection appears similar to other Middle Woodland mound groups located in the floodplain, because it has a high number of Havana sherds and over $30 \%$ of the Havana sherds were decorated (Figure 14).

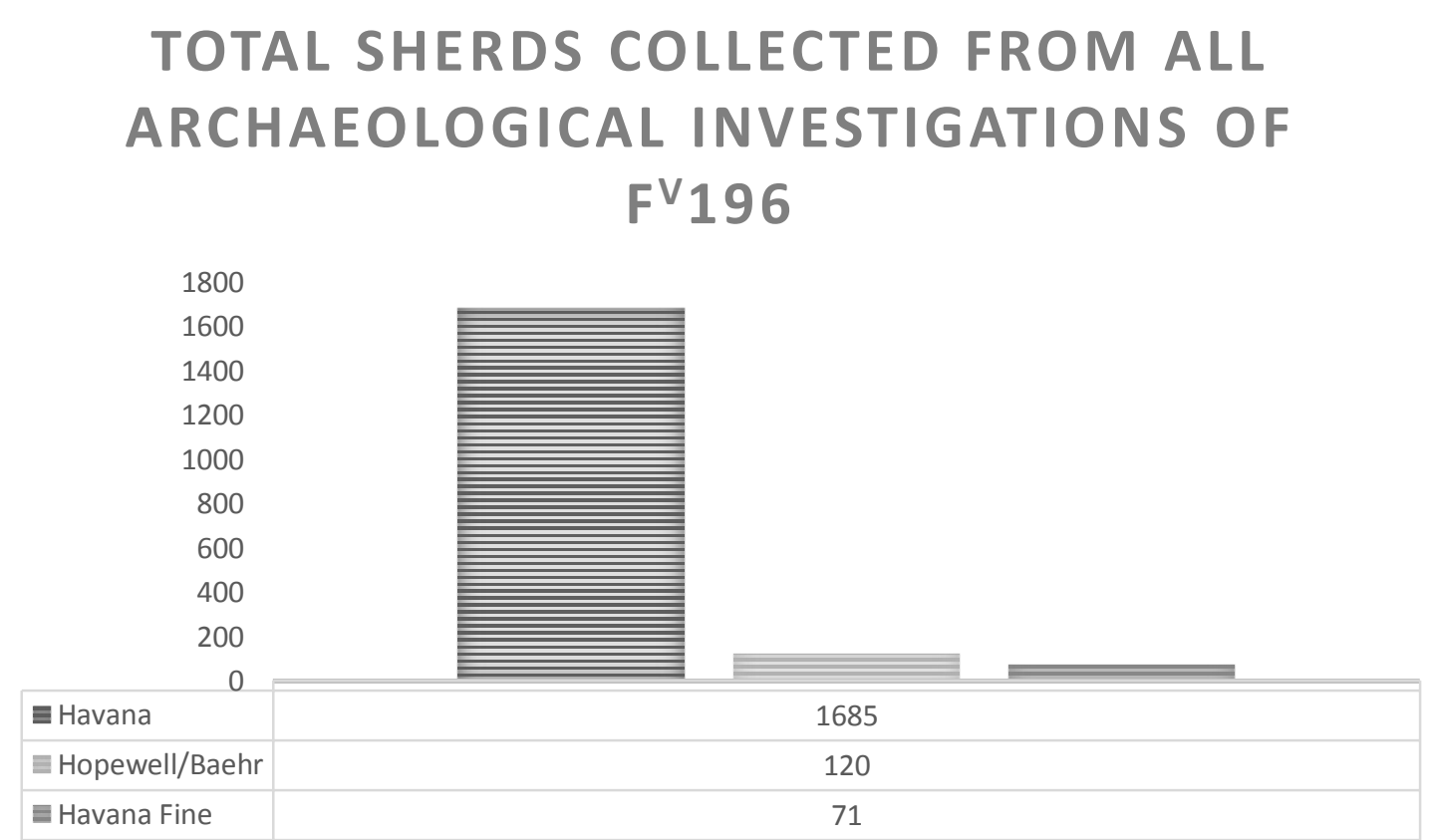

Figure 14: Total Sherds from all Archaeological Investigations of $\mathrm{F}^{\mathrm{v}} 196$. 
There is great varration in the decorations used on pottery from Ogden-Fettie $\mathrm{F}^{\mathrm{v}} 196$. There were a total of 18 Havana decorations and application techniques recognized during this research, the number could be much higher with a more specific typology (Appendix C: 1). The most common decoration on Havana ceramics was Naples Dentate appearing on 300 or $54 \%$ of the sherds decorated and the second most common was Havana Zoned which was seen on 87 sherds, which is $16 \%$ of the total. There were 43 sherds having both Naples Dentate and Havana Zoned decorations. The other forms of decorations were much less common, there were 31 (5.5\%) Burnished, 25 (4.5\%) Neteler Cresent Dentate, 19 (3\%) Cordwrapped Stick Dentate, 18 (3\%) Naples Plain, 14 (2.5\%) Naples Ovoid Stamps, eight (1.5\%) Netler Cresent Plain, seven (1\%) Hummel, five (1\%) Chevrons, five (1\%) Rocker Dentate Stamp, three (0.5\%) Sister Creeks Square Punctate, two (0.5\%) Rocker Netler Crecent, one (0.5\%) Sister Creeks Punctate, one (0.5\%) Stueben Punctate, and Unknown Decorations 37 (6.5\%). The large amount of varation in decorative techniques applied to Havana pottery makes OgdenFettie appear unique. However, decorative variability is not exclusive to Ogden-Fettie as the Havana (Neteler) Mounds appear to have a similar ceramic diversity (McGregor 1952).

The Hopewell sherds showed little varration in decoration types, compared to Havana sherds. Hopewell had a total of six different decorations (Apendix C: 2). The most common Hopewell decoration was Zoning appearing on 26 or $22 \%$ of the Hopewell sherds. Naples Dentate was common as well appeared on 25 sherds making up $21 \%$ of 
the Hopewell collection. There were 10 sherds where both Zoning and Naples Dentate Stamps were applied. Hopewell Punctations and Crosshatched Rims were each seen on 12 sherds and each made up $10 \%$ of the total collection. There were eight sherds that exhibited both Hopewell Punctates and Crosshatched Rims. The Rocker Dentate decoration was seen on five (4\%) sherds and there were three (2.5\%) Montezuma Punctate sherds. Finally, there were four sherds with a Red Slip applied to a Zoned sherd. The remaining sherds were undecorated and it was believed that the number of undecorated Hopewell sherds was inflated, because Hopewell sherds could be identified at a much smaller size than other Middle Woodland sherds. The four decorations that were commonly applied in conjunction with another, suggests that Hopewell sherds had rules for construction.

The great variability in Havana decorations was not seen on Havana Fine sherds, as they exhibited a much smaller variety of decorations, there were only five decoration types (Apendix C: 3 ) and there were 26 or $37 \%$ of the total Havana Fine sherds decorated with Naples Dentate. There were also 11 (15\%) Zoned, nine (12\%) Burnished, eight (11\%) Incised Line Decorations/Chevrons, six (8.5\%) Rocker Dentate, one (1.5\%) Hummel Stamped in a Fettie Neck Band, and there were 16 undecorated sherds. The undeorated Havana Fine sherds were primaraly smoothed and identified by the presenece of shell temper, there was one cordmarked sherd that was included in the Havana Fine category because it was tempered with shell. There were six Havana Fine sherds that exhibited Naples Dentate Stamping and Zoning. The low varriability in Havana Fine decorations points to the series being implemented after the early Havana period when 
there was high decorative variability, or that ceremonial pottery had set rules for construction.

Mound $F^{\circ} 191$. Mound $\mathrm{F}^{\circ} 191$, known as the Mitchel Mound, was originally excavated by the Dickson Brothers, but there is little information about their excavation. Fay Cooper Cole and Fred Eggan re-excavated Fº191 in 1931 (Sheilds n.d.). Fay Cooper Cole and Fred Eggan only excavated 10 grit tempered sherds from the mound. I was only able to located five sherds of the original 10 sherds in the Dickson Mounds Museum collection (Shield n.d.). All five of the sherds were undecorated Havana series sherds that were crudely constructed. The sherds point to a Middle Woodland construction date, but do not reveal which part of the Middle Woodland.

Non-Middle Woodland Pottery

Mound $F^{\circ} 188$. In 1931 Mound $\mathrm{F}^{\mathrm{o}} 188$ was excavated by a party led by Thorne Deuel and Fred Eggan (Figure 18). There were 42 sherds reported as being collected and stored, however, I only found 38 sherds. The 38 sherds I analyzed were very interesting, because they point to an Early Woodland or early Middle Woodland construction date. There were 27 sherds designated as Early Woodland Type Indeterminate. There were 13 of the Early Woodland Type Indeterminate sherds (Figure 15) that exhibited a smoothed exterior surface with large grit protruding from it, which is a Marion tradition (Farnsworth personal comm.). 


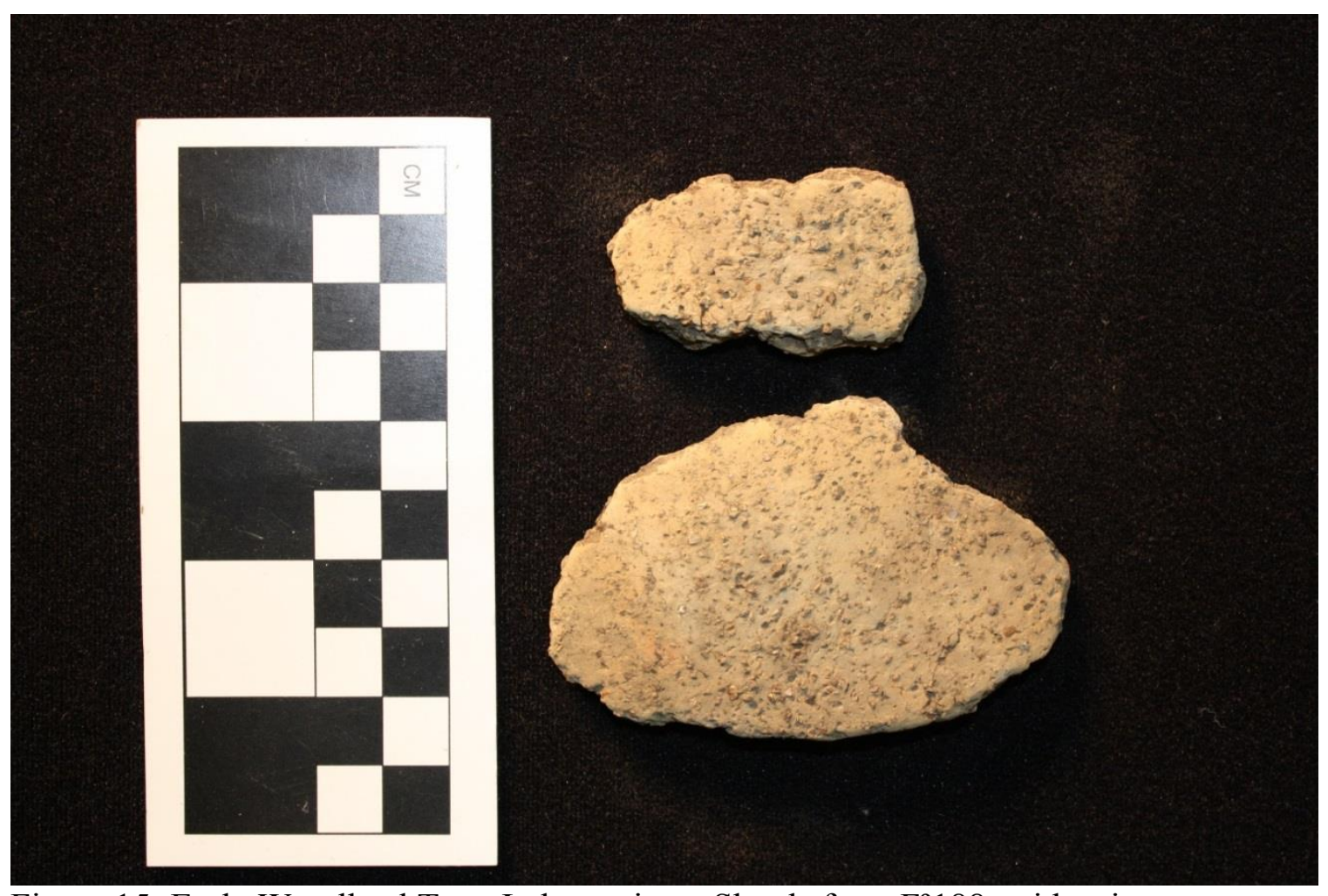

Figure 15: Early Woodland Type Indeterminate Sherds from $\mathrm{F}^{\circ} 188$; with grit temper on the exterior surface (Collection of Illinois State Museum).

The paste and temper of the Early Woodland Type Indeterminate sherds was identical to the Black Sand and Liverpool sherds from the collection. There were a total of 11 typed sherds, eight Black Sand sherds, two Morton/Fettie sherds, and one Havana sherd (Figure 16; Figure 17). The high number of Early Woodland and early Middle Woodland sherds excavated from $\mathrm{F}^{\circ} 188$ in conjunction with the lack of associated artifacts excavated from the mound, points to an Early Woodland or initial Middle Woodland construction date, which means $\mathrm{F}^{\mathrm{v}} 196$ was probably occupied after the mound was constructed. 


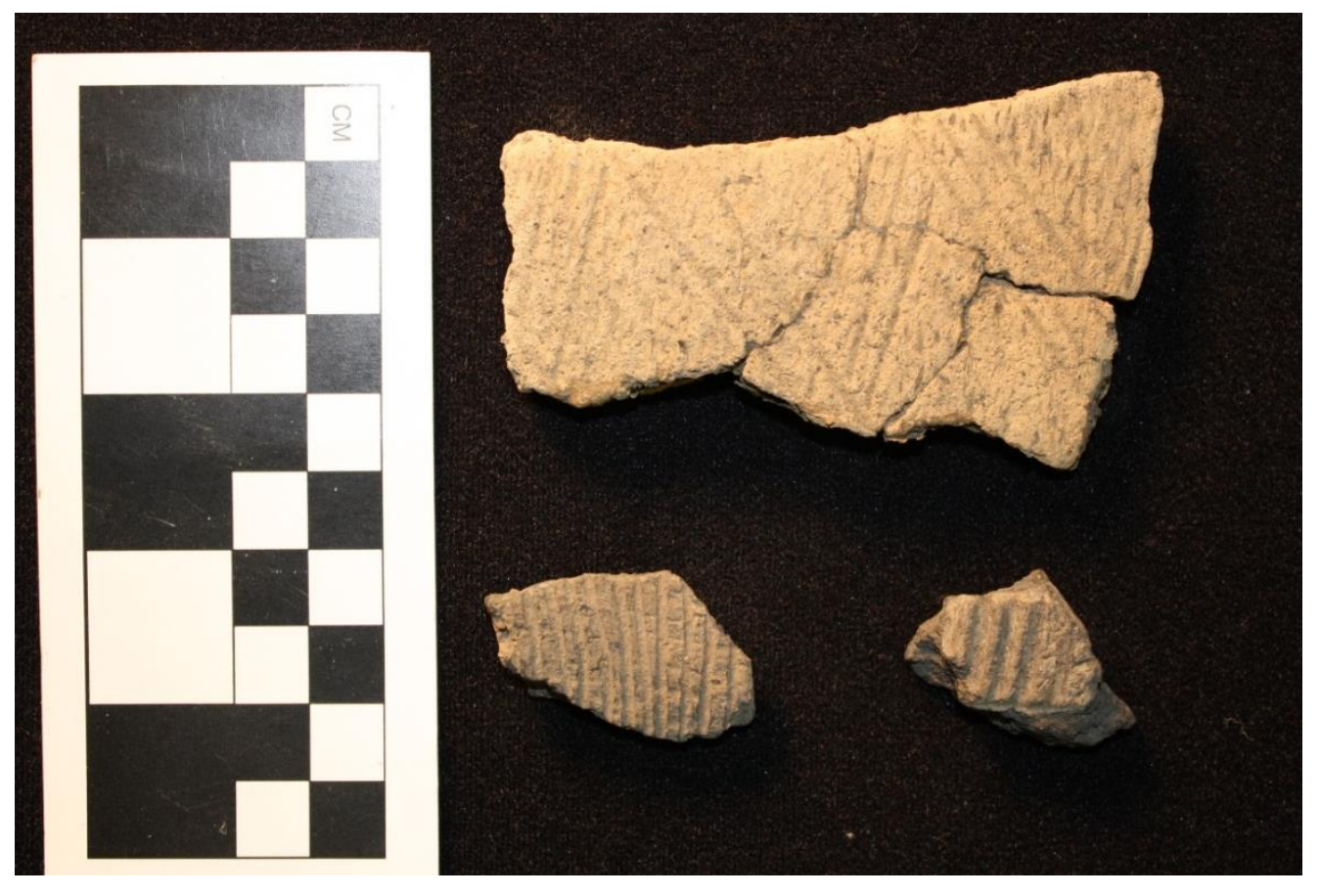

Figure 16: Black Sand Sherds; with Black Sand Incising over Liverpool Cordmarking (Collection of Illinois State Museum).
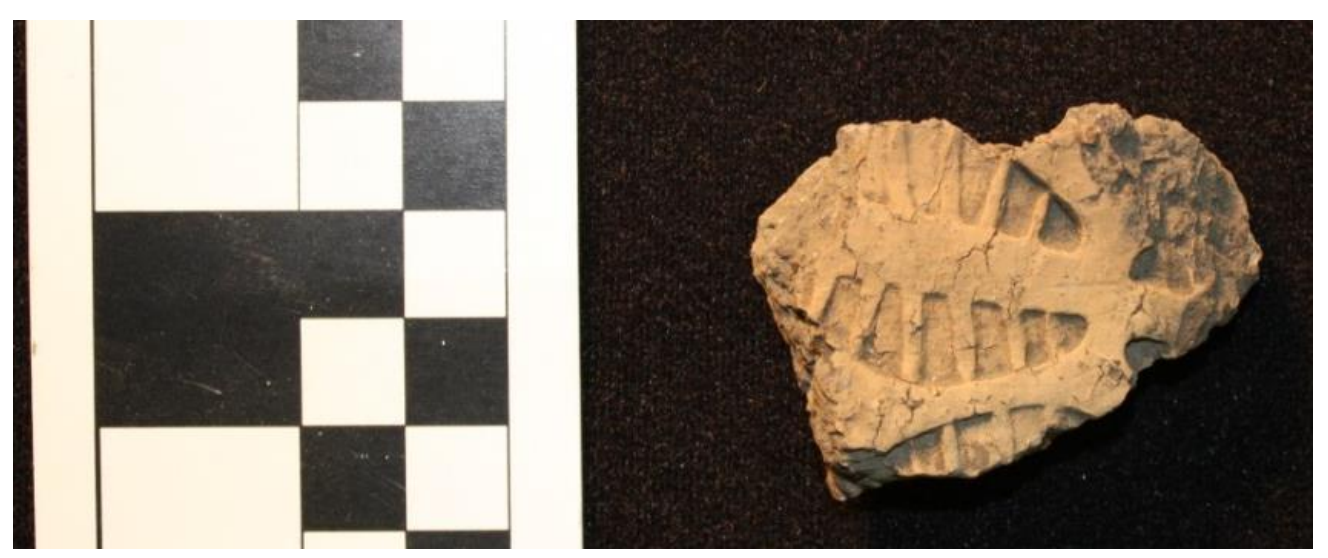

Figure 17: Havana Sherd from $\mathrm{F}^{\mathbf{0}} 188$; with Half a Naples Ovoid (Collection of Illinois State Museum). 


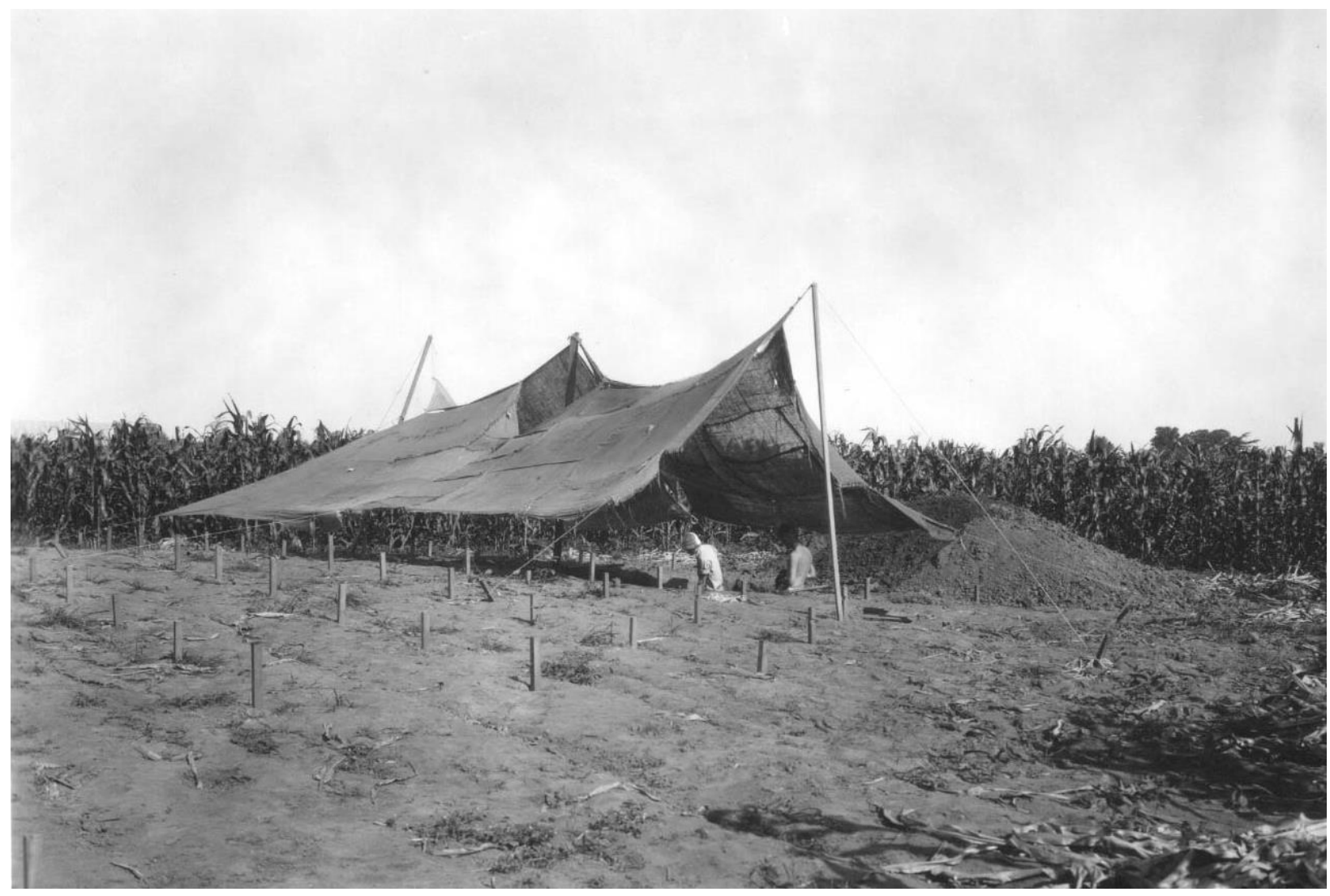

Figure 18: Excavations of Mound $\mathrm{F}^{\circ} 188$ (Collection of Illinois State Museum).

$F^{v} 196$. The investigations at Ogden-Fettie produced 39 Early Woodland sherds. There were six Black Sand sherds, which were identified by the presence of decorations applied over Liverpool Cordmarking. There was one rim that exhibited Black Sand and Havana traits. It exhibited a common Black Sand rim shape and smoothed over cordmarking, but it also had Havana paste, temper, and decorations. I categorized the rim as Havana because the radically different paste and temper. The Crab Orchard and Marion traditions were represented by one sherd each. Overall $\mathrm{F}^{\mathrm{v}} 196$ had a very small Early Woodland assemblage. 
There was a larger Late Woodland ceramic assemblage, but still was small in comparison to the Middle Woodland assemblage. There were 46 Weaver sherds from the Ogden-Fettie collection, including 12 sherds exhibiting a mixture of Weaver and Havana traits, but had a sandy paste placing them in the Weaver Series. There were also three Weaver Bowl fragments with a sandy paste, potentially pointing to a breakdown of ceramic construction rules. The low amount of Weaver potter points to a great reduction in occupation intensity during the Late Woodland.

The Mississippian occupation of the site is also small. There were 21 Mississippian sherds in the collection I analyzed. And 20 of the sherds were excavated from a 20 inch deep pit near $\mathrm{F}^{\circ} 175$ by Struever and Wettersten in 1959. $\mathrm{F}^{\circ} 175$ had an intrusive Mississippian burial which was encounter during the 1929 excavations by Taylor (Figure 10).

\section{Non-Ceramic Artifacts}

There were many non-ceramic artifacts gathered from Ogden-Fettie $\mathrm{F}^{\mathrm{v}} 196$, but I have selected only a few lithic artifacts to publish in this paper. The first two artifacts selected were lamellar blades, one made of Knife River Chalcedony (Figure 19) and the other from LaMoine Chert. The Knife River blade was heavily worn, which Conrad (2004) suggested was from heavy use. The two blades are made from ritual Hopewell Interaction Sphere material, which shows they had a ritual function (Caldwell 1964; Struever 1964). 


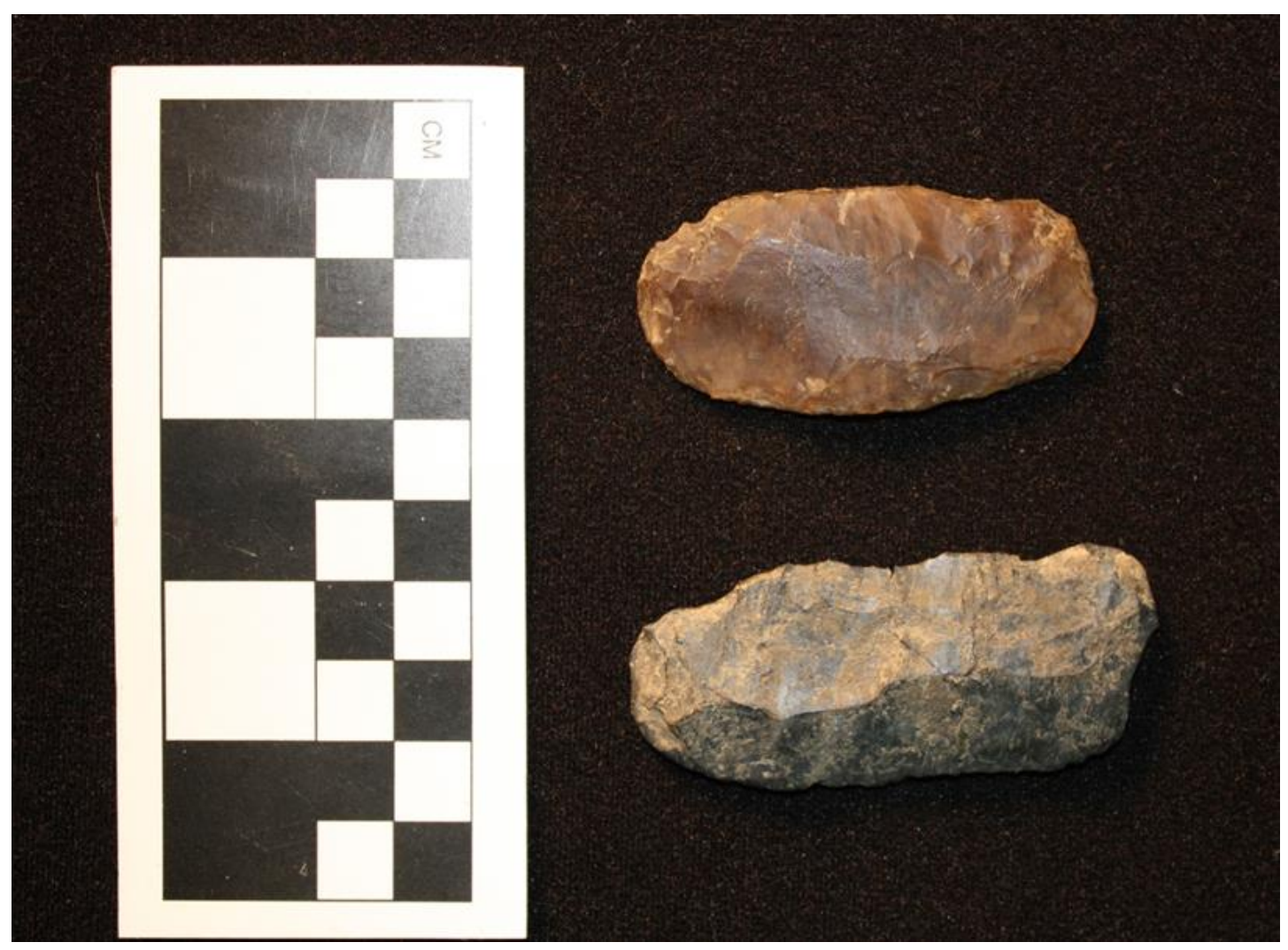

Figure 19: Exotic Lamellar Blades; made from Knife River Chalcedony and LaMoine Chert (Collection of Illinois State Museum).

There also were four Warsaw Tabular Chert objects (Figure 20) one broken Norton point, a Snyders point, an unfinished preform, and one broken preform. Warsaw Tabular Chert is characterized by a thin band of chert in between two layers of cortex. When points are made from the material they are usually flaked in a way to keep the cortex on both sides. Warsaw Tabular Chert is another ritual lithic material (Farnsworth personal comm.). While these five objects were made from exotic ritual material, the other chert artifacts were made of the semi-local materials of Burlington, Dongola, and Cobden cherts; this includes the 100+ remaining lamellar blades and numerous Middle 
Woodland scrapers (Hennessey 1988). Hennessey (1988) interpreted the lithic assemblage as agreeing with Struever and Houart's (1972) claim the site was used as a Ritual Transaction Center. The support for the Ritual Transaction Center is based on the high percentage of the semi-local cherts of Burlington (54\%), Dongola (33\%), and Cobden (2\%), while the long distance trade lithic artifacts were rare, combined they only made up $0.5 \%$ of the total. The lithic material actually refutes the revision made by Struever and Houart (1972) that Ogden-Fettie was a Regional Transaction Center, which is defined by numerous long distance trade items.

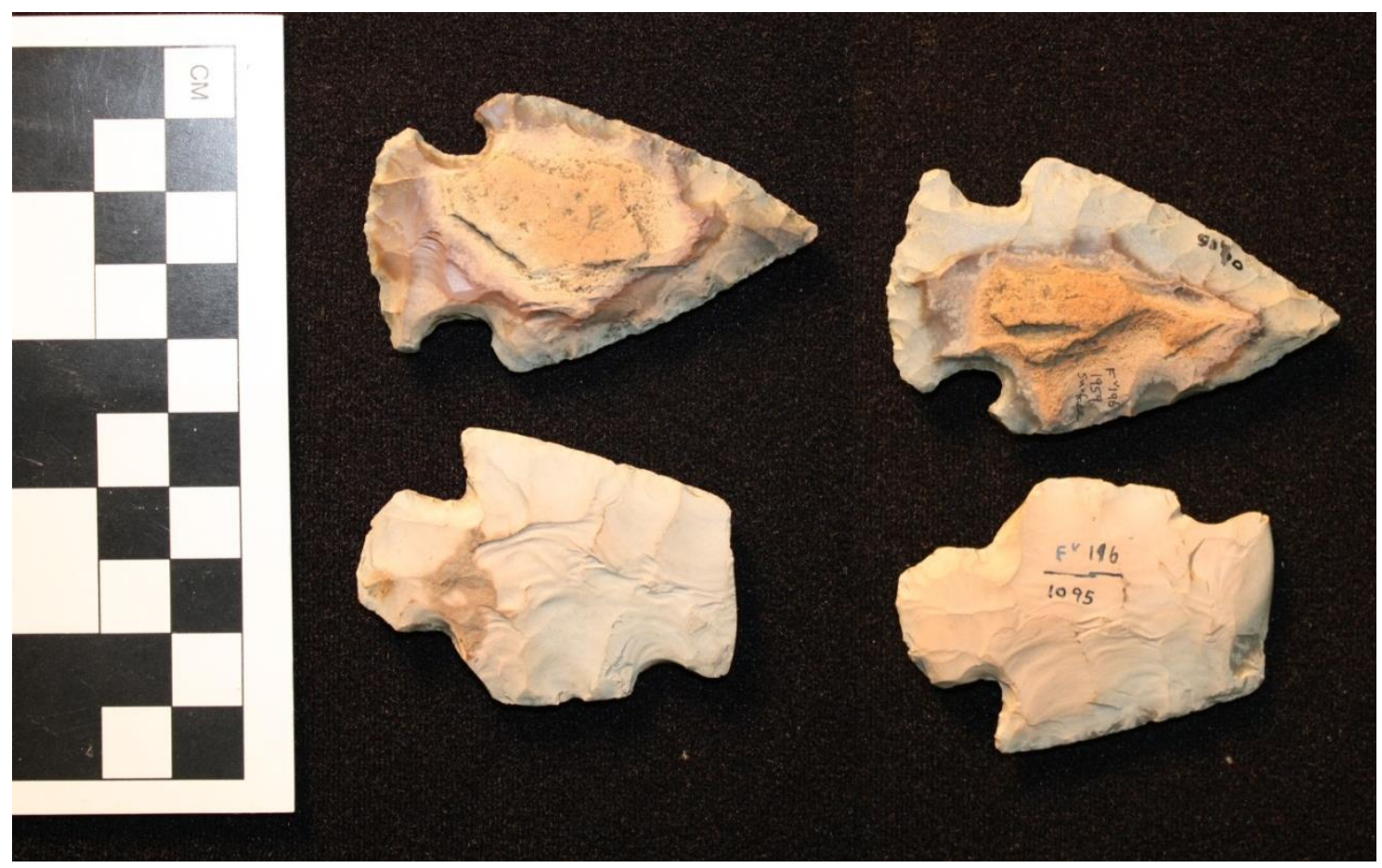

Figure 20: Warsaw Tabular Chert Points (Collection of Illinois State Museum). 


\section{CHAPTER V}

\section{SITE FUNCTION AND FORMATION}

As explained above, Ogden-Fettie is a storied, but mysterious site. The amateur archaeological testing and poorly reported systematic studies makes the interpretation of Ogden-Fettie very difficult and provides ample room for errors. Half of the ceramics came from surface collections with no stratigraphic data and the other half from a mixed midden area with little stratigraphy. The lack of context makes statements about the function of $\mathrm{F}^{\mathrm{v}} 196$ prone to inaccuracies. Although there are issues with the interpretation of Ogden-Fettie, this study attempts to make sense of the previous work and to interpret the function of Ogden-Fettie.

\section{When was Ogden-Fettie Occupied?}

To understand how $\mathrm{F}^{\mathrm{v}} 196$ functioned we first need to consider the timing of the Ogden-Fettie as a whole. The ceramic assemblage from $\mathrm{F}^{\mathrm{v}} 196$ consists of ceramics from the Early, Middle, and Late Woodland pottery, as well a few Mississippian sherds, which means the site was used by ceramic making people from around $700 \mathrm{BC}$ to $\mathrm{AD} 1400$. But the vast majority of the ceramics date from only one era, the Middle Woodland, which dates from around $150 \mathrm{BC}$ to $\mathrm{AD} 400$. Holt (2000) reported uncorrected Middle Woodland radio carbon dates of $\mathrm{AD} 120,130$, and a Late Woodland date of 470. The most common decoration on the Havana sherds was Naples Dentate (54\%) which was 
used most heavily during the Ogden Phase dating to $\mathrm{AD} 1$ to $\mathrm{AD} 150$. The ceramics from the Morton/Caldwell (250 to $150 \mathrm{BC}$ ) and Fulton Phase (150 BC to AD 1) made up a small percentage of the total Middle Woodland sherds found, but they were some of the most interesting.

The sherds identified as early Havana and Morton reveal an intriguing part of the history of Ogden-Fettie. The ceramics from most of the Ogden-Fettie mounds were consistent with Early Woodland and early Middle Woodland types, showing they were probably constructed during those times. It is believed that floodplain mounds were only used early in the Havana-Hopewell culture (Buikstra 1976; Buikstra et al. 1998; Farnsworth personal comm.) Mound construction at Ogden-Fettie probably ended before or during the classic Havana-Hopewell phase, yet people still visited Ogden-Fettie and the size of the Ogden-Fettie midden $\mathrm{F}^{\mathrm{v}} 196$ increased after mound construction had ceased. The determinations about mound construction duration are based mainly on the records supplied by the Dickson brothers and other armature archaeological data and as such do not come with a high degree of confidence. Even the well reported mound excavations do not provide us with any certainty of age, because most the mounds are relatively dated based on sherds. The sherds could have come from mound fill, only showing the mound was constructed sometime after the sherds were deposited. Based on the few reported artifacts and the ceramics collected during excavation I believe at least four of the mounds, $\mathrm{F}^{\circ} 172, \mathrm{~F}^{\circ} 188, \mathrm{~F}^{\circ} 189$, and $\mathrm{F}^{\circ} 193$, were associated with the Early Woodland (Sheilds n.d.). Mounds $\mathrm{F}^{\circ} 36, \mathrm{~F}^{\circ} 166$, and $\mathrm{F}^{\circ} 186$ had attributes of both Early and Middle Woodlands, while mounds $\mathrm{F}^{\circ} 174, \mathrm{~F}^{\circ} 175, \mathrm{~F}^{\circ} 190, \mathrm{~F}^{\mathrm{o}} 191, \mathrm{~F}^{\circ} 192$, and $\mathrm{F}^{\circ} 199$ had 
artifacts that were consistent with other Middle Woodland burial mounds. These determinations are based on the very limited knowledge of the mortuary practices of floodplain mound groups and comparisons with other mound groups. One issue with this timing determination is that the most intensive occupation of $\mathrm{F}^{\mathrm{v}} 196$ would have happened after the mounds were constructed. The strange relationship between $\mathrm{F}^{\mathrm{v}} 196$ and $\mathrm{F}^{\mathrm{o}} 175$ will be discussed more in the latter part of this chapter.

The early Middle Woodland ceramics also provide an opportunity to understand the transition from Early Woodland to Middle Woodland culture. Munson (1982) argued the Early Woodland Marion culture was the sole ancestor of the Middle Woodland Havana culture. He surmised that the Marion and Havana burial rituals were similar, so they must be from the same lineage, while Black Sand rituals were different enough showing they were not part of the same ancestry. Farnsworth and Asch (1986) showed a time gap between the Early Woodland Marion and Black Sand cultures and the subsequent Havana culture in the Lower Illinois Valley (Stretton 2013). At Ogden-Fettie there is direct ceramic evidence portraying a relationship between the Black Sand and Havana cultures, but there were no sherds showing a connection with the Marion tradition (Figure 21). 


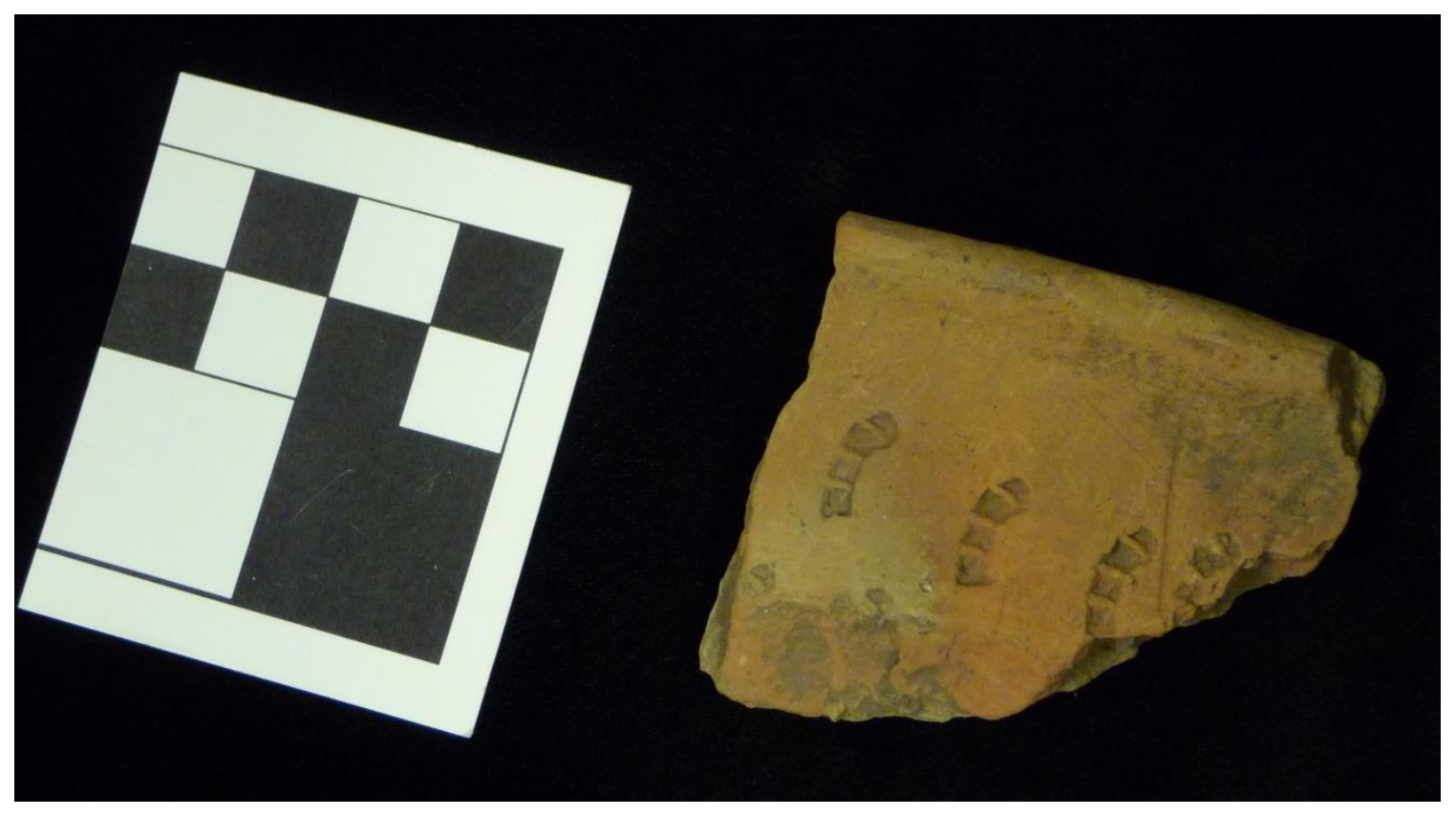

Figure 21: Mixed Trait Sherd; with Black Sand rim profile and Havana paste and decorations (Collection of Illinois State Museum).

There are mixed trait sherds that had a Black Sand rim shape and large grit Havana temper and Havana decorations, while other sherds that have Black Sand decorations with large grit Havana temper (Figure 21). The mixed trait sherds show a strong connection between the Black Sand and Havana culture. The connection between the Marion and Havana traditions is not seen at Ogden-Fettie probably because the Marion occupation was small, represented by one possible sherd. The sherds exhibiting a mixture of traits points to a rapid transition from the Black Sand phase to Morton/Caldwell phase, probably only a generation or two. The mixed sherds from Ogden-Fettie show a continuum from the Black Sand to the Havana ceramic tradition. 
A continuum from Havana to Weaver is also apparent in the ceramic collection. The Weaver component at Ogden-Fettie $\mathrm{F}^{\mathrm{v}} 196$ is small and was made up of 46 sherds and 12 of those had a mixture of Havana and Weaver traits. Most of the mixed trait sherds had the Havana traits of nodes and beveled rims, but had the Weaver traits of thin walls and a sandy paste. There were three Weaver sherds that had the Hopewell characteristic of having a bowl form. These sherds support the assertion that Hardin vessels represented the times when no Hopewell pottery was available; however, as mentioned previously I believe Hardin needs to be broken into two groups (Staab 1984)

- $\mathrm{F}^{\mathrm{v}} 196$ was used by the Early, Middle, and Late Woodland people and had a later Mississippian use as well.

- Some of the Ogden-Fettie mounds were probably constructed during the Early Woodland, which was before $\mathrm{F}^{\mathrm{v}} 196$ was heavily used.

- The most intensive part of the occupation of $\mathrm{F}^{\mathrm{v}} 196$ was during the Middle Woodland and it was occupied most heavily during the Ogden phase AD 1 to $\mathrm{AD}$ 150.

- The Early Woodland Black Sand culture was a direct ancestor of the later Middle Woodland Havana culture.

How did Fv 196 Function?

The model laid out in Struever (1968b) provides a framework through which many have attempted to understand the function and settlement of Middle Woodland sites, but the model appears to have problems with some of its suppositions (eg., Buikstra et al. 1998; Farnsworth 1990; Farnsworth and Koski 1983; Staab 1984; Stafford and Sant 
1985; Wiant and McGimsey 1986). The model relies on the assumption that some pottery is used solely for habitation purposes (Havana), while other pottery was strictly for ceremonial activities (Hopewell). The postulation about the ceramic dichotomy has multiple flaws that have come to light in the 45 years since Struever first created the model.

Struever (1968b) believed Havana ceramics were used as cooking pots. Indeed, most of the Havana rim sherds from Ogden-Fettie had charred material and/or a scum line showing they were used for cooking. However, some Havana pottery (Havana Fine) that is normally attributed to the Havana series was probably used in a ritual context. The model also assumes that cooking is only a subsistence function and did not consider ritual food consumption. The cooking associated with ritual feasts was most likely carried out using Havana pots, but highly decorated pots (Morgan 1986; Wiant and McGimsey 1986). I propose that feasting may be visible archaeologically in the form of a high percentage of decorated shreds. At the ritual site of Napoleon Hollow Block IV, 34\% of the Havana ceramics were decorated (Morgan 1986), which is compared to the $6 \%$ decorated Havana sherds from Smiling Dan (Morgan 1985) the habitation site located just across the river (Table 1). Peisker had 27\% decorated rim sherds and the two bluff top sites of Dickson Camp and Pond which are located near Ogden-Fettie had 5\% and 16\% decorated Havana sherds respectively (Cantwell 1980; Staab 1984). Ogden-Fettie is most similar to Napoleon Hollow Block IV in percent of decorated sherds, at 33\%; however, when Struever (1968b) is applied to all of these sites, none of them, with the exception Napoleon Hollow Block IV, appear to have a ceremonial function. Smiling 
Dan, Dickson Camp, and Pond all fall firmly in the habitation category, because of numerous pit features, diverse faunal assemblages, and a high proportion of Havana pottery.

The two problematic sites of Peisker and Ogden-Fettie do not fit perfectly into any of the categories. Staab (1984) argued that Peisker should be considered a major multi-purpose camp, because it was the location of many different activities, including mortuary rituals. Ogden-Fettie appears similar to Peisker archaeologically, because it has subsistence tools, a high proportion of Havana sherds, very few pit features, and is located near a mound group. The big difference comes when the percent of decorated Havana sherds is compared. Only rim sherd totals were presented in Staab (1984). Her table showed that $27 \%$ of the rim sherds were decorated. Ogden-Fettie on the other hand had a much higher decorated rim sherd percentage of $97 \%$, which suggests the sites functioned differently and possibly had differential timing.

In 1972 Struever and Houart reworked Struever's (1968b) settlement and function model and relabeled Ogden-Fettie as a Regional Transaction Centers. They believed a Regional Transaction Center should have a high proportion of Hopewell Interaction Sphere items and be located near a major trade highway (Caldwell 1964; Struever 1964; Struever and Houart 1972). They identified Ogden-Fettie and the geometric earthworks at Golden Eagle as Regional Transaction Centers and demoted Mound House to a Floodplain Mortuary Camp. The identification of Ogden-Fettie as a Regional Transaction Center was based upon its location and size, not the associated artifacts. As such Ogden-Fettie does not fit the Regional Transaction Center model, because while it is 
located near a major highway, the Illinois River, it only has a few Hopewell Interaction Sphere objects. The low number of ritual Hopewell Interaction Sphere items suggests that only a few ritual objects passed through or were traded at Ogden-Fettie (Hennessey 1988; Holt 2000).

The settlement and function models proposed by Struever (1968b), Struever and Houart (1972), and the modified model from Staab (1984) are all insufficient to describe Ogden-Fettie. $\mathrm{F}^{\mathrm{v}} 196$ fits parts of each proposed models, but fails to conform to others. $\mathrm{F}^{\mathrm{v}} 196$ had a high proportion (89.5\%) of habitation category Havana pottery, a low number of pit features, and is associated with burial mounds showing it doesn't fit into the categories mentioned in Struever (1968b). Struever and Houart (1972) believed it was a Regional Transaction Center which is characterized by a large amount of ritual trade items, but there were only a few long distance trade items showing it did not fit the description. The archaeological remains from Ogden-Fettie are similar to Peisker, except for a higher percentage of decorated pottery and a lack of permanent structures. The difference in amount of decorated pottery shows a difference in function. Ogden-Fettie and Peisker were both mortuary gathering sites, the difference was that Ogden-Fettie was a gathering site, where inter-regional groups came together to build a regional identity, while Peisker represented a local community gathering site (Asch et al. 1979; Staab 1984). The activities associated with the formation of $F^{v} 196$, consisted of food preparation and consumption as shown by the $89.5 \%$ Havana sherds collected from the site. The midden was most likely associated with ritual food consumption, as evident by the $33 \%$ of Havana sherds that were decorated. I interpret the Ogden-Fettie midden as 
being an aggregation site where feasting may have taken place and believe that function needs to be added to the original model from Struever (1968b). An Aggregation Site is defined by have a large amount of decorated ceramics, a low amount of pit features, and normally is located near mounds. Struever and Houart (1972) may have been describing Ogden-Fettie as a place of aggregation where social transactions took place. It is important to note that this is my interpretation based on only a small percentage of pottery from one Central Illinois Valley site.

The sites of Napoleon Hollow and Ogden-Fettie fit into the Aggregation Site category, but the activities preformed at the sites may be different (Struever 1968b; Wiant and McGimsey 1986). Napoleon Hollow Block IV is associated with the bluff-top mound group of Elizabeth Mound. Napoleon Hollow and Elizabeth Mounds probably only serviced the mortuary needs of the local community from the Smiling Dan site, while Ogden-Fettie appears to have acted as a burial site for a much larger area (Buikstra 1976; Wiant and McGimsey 1986). Feasting remains at Napoleon Hollow were represented by $34 \%$ decorated Havana sherds, a low amount to pit features, a high number of lamellar flakes, and its proximity to the Elizabeth Mounds. There was also a high amount of tender cuts of venison, suggesting ritual meat selection.

Ogden-Fettie $\mathrm{F}^{\mathrm{v}} 196$ is similar, but not perfectly comparable to Napoleon Hollow. $F^{\mathrm{v}} 196$ was similar to Napoleon Hollow, because $\mathrm{F}^{\mathrm{v}} 196$ had a high number of decorated ceramics, low number of pit features, and was near the Ogden-Fettie mounds. But differed in that it had diverse faunal remains and there was no preference for select cuts of deer meat. Holt (2000) surmised the diverse faunal assemblage was not an indication 
of a temporary use mortuary site, nor was it an indication of ritual feasting, but she did not rule out those functions.

Floodplain mound groups may have been gathering locations for regional groups (Buikstra 1976). $F^{\mathrm{v}} 196$ had great diversity in decoration types with a total of 18 identified, showing a possibility of multiple distinct ceramic groups. The number of types could have been much higher, but many of the decorations were seen in low numbers at Ogden-Fettie and comparable sherds from other sites were not available. Napoleon Hollow had only 11 decorations present (Morgan 1986; Wiant and McGimsey 1986). The difference is larger if only Block $I$, the refuse area, from Napoleon Hollow is considered, with only five decoration types present, and four of the five decorations from Block I were also present at habitation site of Smiling Dan. Block IV at Napoleon Hollow had 11 decorations present, including the early Havana decorations of Pinched and Naples Ovoid Stamping. None of the 11 types were unique as they are seen at Ogden-Fettie and other Havana sites from Illinois River Valley.

The typed ceramics from Ogden-Fettie were for the most part decorations seen at other sites. Only two of the Neteler varieties of Neteler Quarter Crescent and the Rockered Neteler Crescent were unique to Ogden-Fettie. There were also 37 decorated sherds in the $\mathrm{F}^{\mathrm{v}} 196$ collection that could not be typed, because the decorations were completely unique. The sherds appear similar in size, paste, and temper to Black Sand and early Havana sherds, showing they probably originated from the transitional years between the Early Woodland and the Middle Woodland. Overall the 37 unique sherds represent only $6.5 \%$ of the total decorated sherd collection, but the few sherds are 
informative. The diverse and unique decorations suggest a gathering of early disparate ceramic groups in a central location. When groups are separated the ceramics usually take on unique characteristics and decorations, because each group had their own ideas about how a pot should be constructed and decorated. The dispersed early Middle Woodland groups would coalesce at $\mathrm{F}^{\mathrm{v}} 196$ to perform rituals that most likely revolved around feasting and burials (Buikstra 1976). As the Middle Woodland progressed contact between Havana groups increased and the diversity in decoration types was replaced by a finite set of decorations. Braun (1977) notes that the suite of decorations used by Havana potters changes and decreases over time; and the changes in decorations are seen at most Havana sites. The uniform changes in decorations shows that Havana people were interconnected.

While the diversity of decorations decreased over time, the amount of decorated pottery did not change, showing the continuation of the aggregation rituals, possibly revolving around feasting, burial, and mound construction. Aggregation rituals are commonly used to create alliances. Hayden (2003) explained that people often created alliances at such events to protect groups during times of war and low food yields (Dillehay 1990). Marriage alliances could also be constructed at aggregation events, which would promote familial proliferation and genetic potency. Alliance building may have been one of the functions of Ogden-Fettie.

Rituals can also be used to create a shared history. The construction of mounds requires a large amount of energy, which usually means an entire community is needed to construct a mound. The Ogden-Fettie cemetery mounds were constructed, as many 
mounds were, by dumping basket loads of dirt into a pile until a mound emerged (Figure 22). The act of building a mound creates a sense of community through a shared history. Once completed the mounds were permanent markers that showed a group's ownership over an area and reminded regional groups of their shared history (Dillehay 1990; Renfrew 1976). While working in Chile, Dillehay (1990) found that only high ranking Mapuche people were buried in mounds and only the members of the high ranking person's extended family helped to construct the mound. Further, he claimed that the mounds were used to legitimize the power of influential families. Albrecht (2013) suggests a similar pattern in Middle and Late Woodland mounds, where she believes that the mounds were used as extended family burial plots. 


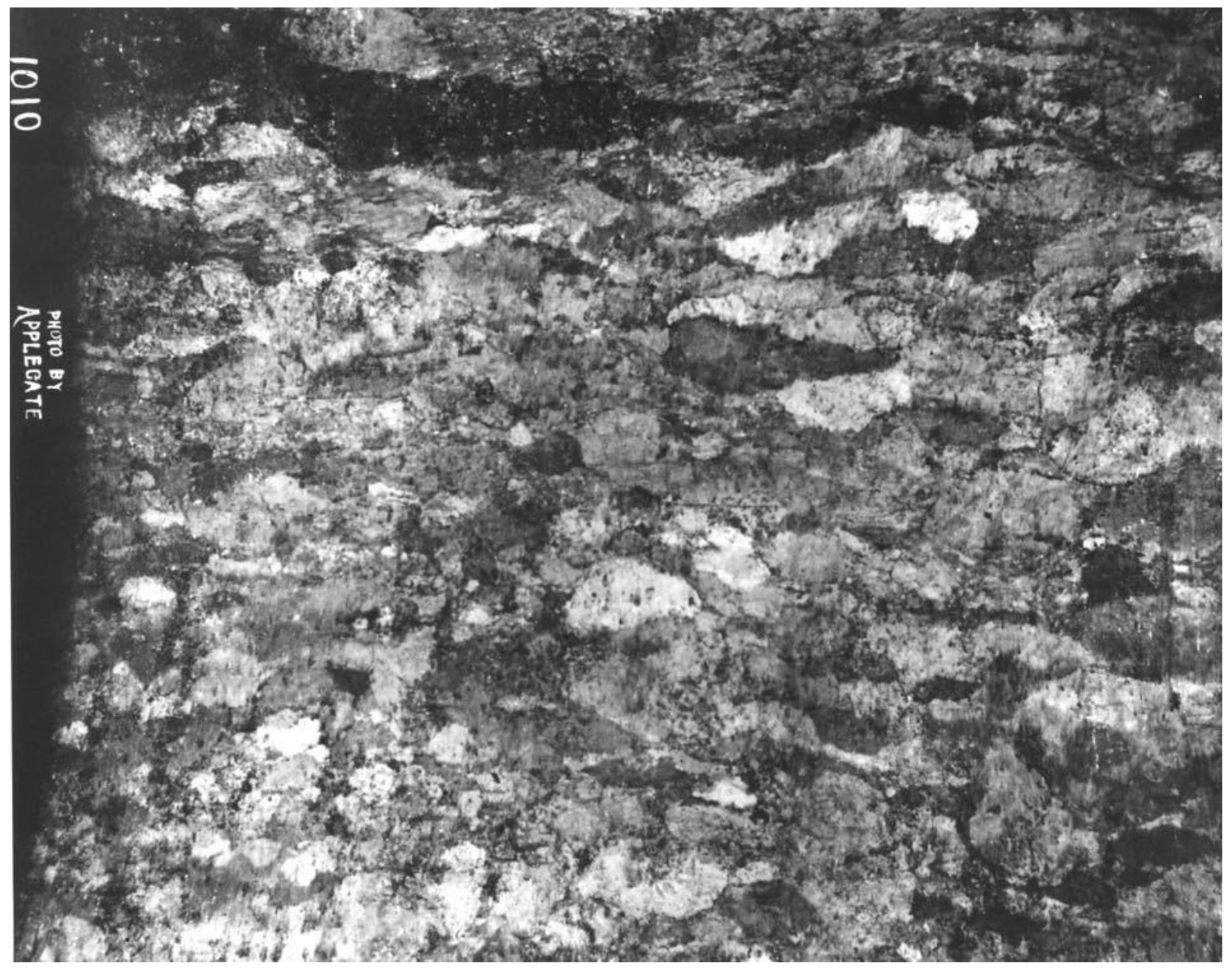

Figure 22: Mound Fill from $\mathrm{F}^{\mathbf{0}} 175$; showing basket loading (Collection of Illinois State Museum).

Mound construction is a labor intensive task that required surplus labor and resources to complete. Hayden (2003) explained that groups in some communities spend immense amounts of money to put on elaborate burial rituals. The rituals are not for the dead as one might expect, rather they are used to showcase a family's wealth and prosperity. Families could show their virility by building mounds and by burying the 
deceased with grave goods. The families were rewarded for their large expenditure through marriage, trade, or military alliances (Dillehay 1990; Hayden 2003). These social transactions may be what Struever and Houart (1972) were suggesting by labeling Ogden-Fettie a Regional Transaction Center. The mounds at Ogden-Fettie could represent a family or groups attempt to increase their power and prestige. Once the last mound at Ogden-Fettie was built, the mound group continued to be visited causing the size and depth of the midden $\mathrm{F}^{\mathrm{v}} 196$ to increase. The post mound construction function of $\mathrm{F}^{\mathrm{v}} 196$ may have been an annual or semi-annual mound capping ritual, where people continued to return and add to the mounds as a way to pay homage to their predecessors (Dillehay 1990). The capping rituals were a way to show a families continued reverence for ancestors and to prove their virility was still intact (Dillehay 1990; Hayden 2003; Renfrew 1976).

The Ogden-Fettie mounds may represent the burial needs of a dispersed group. Albrecht (2013) found that the Middle Woodland mound complex of Albany had a mix of 161 primary burials and 83 bundle burials. While at Ogden-Fettie there were a total of 34 primary burials and 57 bundle burials reported, most of which were identified by amateur archaeologists (Sheilds n.d.). Bundles may represent people who died far from the burial ground, as it is easier to carry a bundle of bones rather than an extended body (Albrecht 2013). Middle Woodland mound groups have a higher occurrence of bundle burials than Late Woodland sites, suggesting the Middle Woodland burial sites serviced a more dispersed population (Albrecht 2013). Alternatively they may have died at a time of year mound construction was not possible for natural or cultural reasons. Bundles 
were probably created by defleshing or natural decomposition of a body, leaving only bones. The disarticulated bones were then collected and transported to a mound group for interment. Extended burials might represent burials of individuals who died in close proximity to the burial mounds or who died at a time burials were possible. The higher amount of bundle burials suggests that distant groups carried their dead to the burial mounds for interment. The collection of groups may have feasted using their most highly decorated pottery, which could account for the highly decorated and diverse ceramic assemblage. After the ritual had been completed the groups would disperse into semiisolated groups.

- Ogden-Fettie does not represent any of the settlement types from Struever (1968b).

- Ogden-Fettie was not a Ritual Transaction Center as defined by Struever and Houart (1972), but was possibly a place for social transactions.

- Ogden-Fettie was not an elite residence.

- Ogden-Fettie was an Aggregation Site, where isolated regional groups congregated possibly to feast and build mounds.

- The groups used burial rituals and mound construction to build a shared history and procure alliances.

\section{Havana Fine}

The proposed ceramic series of Havana Fine is mentioned in many reports, but usually it is presented as an oddity or mentioned only in passing (Cantwell 1980; McGregor 1952; Staab 1984; Wettersten 1960; Wray and MacNeish 1961). In the course 
of my study of the Ogden-Fettie ceramic material I encountered many sherds that did not fit into the Havana, Hopewell, or any other category well. There were very finely made Havana pots with thin walls, delicately executed designs, and stereotypically Hopewell designs. These factors led me to the belief that the Havana Fine pottery may have a separate ceremonial function. To avoid any ambiguity and improper classification I attempted to create narrow guidelines. However, admittedly the rules are too confined, so some complete Havana ceremonial pots found in burial and ritual context are too large and would not fall within this category. Hardin series is similar to Havana Fine, but it was not used to classify the sherds because the definition of Hardin included fine vessels from the beginning and end of the Havana ceramic tradition (Staab 1984). There are a host of mound centers, Havana, Utica, Naples, and Norton just to name a few, that have Havana Fine pottery included in the burials (McGregor 1953; Taylor 1929; Griffin et. al 1970; Henriksen 1957). The inclusion in burial contests shows that Havana Fine sherds represent ceremonial pottery, and relative dating suggests they are most heavily used by the early Havana culture.

Havana Fine pottery like Hopewell pots are used in ritual burial contexts, but they also have other attributes in common with Hopewell pottery, they usually are grit tempered sherds that are finely decorated and are small with orifice diameters less than $20 \mathrm{~cm}$. Some have flat-bases, which is believed to show a function that included being placed on multiple surfaces. The flat-bases are opposed to the conical bottomed Havana cooking pots. Havana Fine sherds can be distinguished from the sherds exhibiting Hopewell and Weaver (Late Woodland) attributes by examining the paste and temper. 
Havana Fine sherds from Ogden-Fettie had poorly mixed grit temper resembling the temper in local Havana vessels. The sherds representing the blending of the HavanaHopewell and the Weaver ceramic traditions had a sandy paste and temper. At other sites the Havana Fine sherds should resemble the Havana sherds in every way except size, thickness, and decoration. The definition of Havana Fine is based mainly upon the Ogden-Fettie assemblage, so further refinement will be required. In future studies I recommend Weaver pottery having Hopewell characteristics be defined as Hardin series, but I have not drafted guidelines.

In all there were only 71 of Havana Fine sherds collected from Ogden-Fettie. The Havana Fine pottery was probably only used during the first two Middle Woodland phases (Morton/Caldwell Phase and Fulton Phase), after which it appears Havana Fine pots were replaced by Hopewell ceramics. The apparent replacement of the Havana Fine pottery by Hopewell pottery makes a compelling case for Havana Fine ceramics having a ceremonial function.

One of the most interesting findings from the analysis of the $\mathrm{F}^{\mathrm{v}} 196$ ceramics was the discovery of shell tempered Havana Fine sherds (Appendix D: f) There were 21 sherds in all from what appears to be two to three pots. At first it was assumed that the temper was a result of inclusions in the clay, but the amount of shell and the extent to which it was mixed suggests the temper was a choice and not a random inclusion. The shell does not appear to be mussel shell like later Mississippian sherds, instead the shells are probably from small snails, however, further testing is required to determine the type of shell used. McGregor (1952) mentioned sherds tempered with snail shell from the 
Havana mounds, he ascribed them to his Neteler series, which appears to be similar to my Havana Fine series. Both Ogden-Fettie and the Havana mounds have plain shell tempered sherds that are extremely polished (McGregor 1952). Shell tempered Havana sherds are not seen anywhere else but these two sites, which suggests the sites were probably used by the same group of people. Most of the ceramics from Havana (Neteler) Mounds are made with the recent early Havana styles, suggesting the site was were probably created after the last mound at Ogden-Fettie had been constructed. All of the shell tempered sherds from Ogden-Fettie were classified as Havana Fine ware because the rim and decorated sherds appeared to fall well into the Havana Fine category and the temper choice was assumed to have a ritual significance.

Havana Fine pottery will be integral in understanding the function of preHopewell Havana sites, because it appears to have a ritual function. Havana Fine pottery has only been noted in mound context or at sites directly associated with mounds. Identifying it will also help to decipher the percent of decorated Havana ceramics at sites with mounds, because Havana Fine pots tend to be highly decorated. Finally, the presence of Havana Fine pots shows that Ogden-Fettie is one of a few early Havana sites. Is it Unique?

Over the years there has been much speculation about the importance of OgdenFettie. It has been referred to as the primordial center for the Havana culture, called one of the most unique and important Illinois Hopewell site (Cole and Deuel 1937; Farnsworth personal comm.; McGregor 1952; Sheilds n.d.; Struever and Houart 1972). The imposing size of $\mathrm{F}^{\circ} 175$ was the basis of many of the claims, but ceramics also 
support the claims of uniqueness.

As stated above some of the ceramics from Ogden-Fettie were unable to be typed because they were unique. The true number of unique sherds may be larger than I have depicted, because it was the original project design to try and classify sherds, so I grouped sherds that should have been separated. The 37 (6.5\%) unique sherds do show the site is different than most other Havana-Hopewell sites. Unique sherds have been highlighted at sites near Ogden-Fettie, but rarely are mentioned outside of the Central Valley (Cantwell 1980; McGregor 1952). These unique sherds suggested that the formation of Ogden-Fettie is different than many other sites. Even the typed sherds show a different history, with at least 18 different decorations present. The sites of Dickson Camp and Pond are located on the bluffs overlooking Ogden-Fettie, but the two Havana sites only had 10 decoration types between them (Cantwell 1980). The Havana (Neteler) site located on the opposite side of the Illinois River and just a few kilometers downstream from Ogden-Fettie seems to be the only site with comparable ceramic diversity, but has its own unique set of pottery decorations (McGregor 1952). The true diversity is unknown, but the photos in McGregor $(1952: 72,76,85)$ depict diversely decorated pottery. The pottery from the Havana (Neteler) Mounds appears almost identical to that from Ogden-Fettie, though I have only glanced at the Havana (Neteler) Mound collection. Both sites have shell tempered and highly polished sherds which have not been seen at other Havana sites (McGregor 1952). The nearly identical ceramic collection points to the same group constructing and occupying both sites.

The ceramic assemblage from Ogden-Fettie is identical to other Havana- 
Hopewell sites in many ways; however, there is a small portion of the assemblage that is unique. The portion of unique sherds points to a site history that is different than other Havana-Hopewell sites. Ogden-Fettie and the Havana (Neteler) Mounds may be the birthplace of the Havana culture (Farnsworth personal comm.). F Fv196 showed a ceramic continuum from the Early Woodland Black Sand pottery, to the Middle Woodland Havana pottery, and finally to the Late Woodland Weaver pottery. There is also Mississippian pottery at the site, but it appears to show up after a break in the ceramic sequence. The sherds with a mixture of Black Sand and Havana traits show a ceramic evolution took place at Ogden-Fettie. The ceramic evolution does not prove OgdenFettie was the birthplace of the Havana culture, but does show it was occupied during the transitional years.

- The Early Woodland and early Middle Woodland Assemblage at Ogden-Fettie are unique or at least part of a unique group of Central Illinois River Valley sites.

- Ogden-Fettie and the Havana Mounds were probably occupied by the same people and may represent the birthplace of the Havana culture.

\section{Conclusions}

Ogden-Fettie is one of at least two unique sites that have characteristics that make them difficult to compare to other Middle Woodland sites. $F^{\mathrm{v}} 196$ is hard to compare because it was occupied throughout all three Woodland periods and there is little known about the stratigraphy at the site. The long time frame and lack of stratigraphic data makes it hard to understand the site formation processes that created $\mathrm{F}^{\mathrm{v}} 196$. With those constraints I believe that some general conclusions can be made about the site. 
- The mounds at Ogden-Fettie were probably constructed before the most intensive use of $\mathrm{F}^{\mathrm{v}} 196$.

- Ogden-Fettie and the Havana (Neteler) Mounds were some of the earliest Havana cultural centers and possibly the earliest.

- There is a large amount of ceramic diversity at $\mathrm{F}^{\mathrm{v}} 196$ which showed a collection of isolated groups met at Ogden-Fettie during the Early Woodland and early Middle Woodland. Later the ceramic diversity decreased as the isolated groups became more integrated into the Havana society.

- Ogden-Fettie $\mathrm{F}^{\mathrm{v}} 196$ has unique features in the way of its Early Woodland and early Middle Woodland assemblages, but the other ceramics are identical to Middle Woodland sites throughout the Illinois River Valley.

- $\mathrm{F}^{\mathrm{v}} 196$ was a ceremonial location were one or a few extended families met for rituals. The high number of decorated Havana ceramics suggests it may have been used for ritual food consumption during mound construction or burial ceremonies.

- Havana Fine and Hopewell vessels probably had identical functions, but were used in two different part of the Middle Woodland. Havana Fine pots were used first during the early Middle Woodland (Morton/Caldwell and Fulton Phases) and were replaced by Hopewell vessels during the Classic Middle Woodland and Late Middle Woodland (Ogden and Steuben Phases). 


\section{Future Research}

The enthusiasm for Middle Woodland research in the Central Illinois River Valley has waned greatly since its heyday in the early to mid- $20^{\text {th }}$ century. The reduction in interest has left an area rife with Havana-Hopewell archaeology almost devoid of Middle Woodland research. Studies on sites in the Central Illinois Valley would be helpful in understanding the beginning and possibly the end of the Havana culture. Systematic studies on Havana ceramics could provide some of the most helpful insights into the formation of Havana sites in the Central Illinois Valley.

The series determinations that work well in other parts of the Illinois River Valley are less than ideal for application to the Central Illinois Valley. At other areas of the Illinois River Valley Pike pottery is limestone tempered, while in the Central Valley it is grit tempered, Havana Fine vessels do not exist, and there is a clear separation between Black Sand and Havana ceramic styles. The Central Illinois River Valley is also home to some of the most extreme diversity in decorations showing that ceramic groups were isolated at certain times. A systematic study and typology that considered the diversity and temporal concerns of the Central Illinois Valley sites of Havana, Sister Creeks, Clear Lake, Weaver, and Liverpool would go far in advancing the study of the Havana Culture. A study of these mound centers could also lead to the location or locations where the Havana Culture first developed and would give us a chance to study the rapid cultural changes associated with the development.

Further research needs to be done on understanding the relationship between technical choices (temper type, size, thickness, etc.) and vessel performance (see Skibo 
2012) In addition, more precise functional arguments would benefit from a use alteration analysis (attrition, carbonization, and residue) that would allow us to determine what was being processed in the vessels and the associated use activities. Havana Fine and Hopewell pottery both represent a ceremonial ceramic form, interestingly both exhibited scum lines showing they had been used for some form of cooking (Skibo 2012). Use alteration analysis of the pots would be useful in determining their actual function. A lipids analysis could reveal what was being cooked in the pots from the two series and when they were used. If the decoction method seen on Ramey vessels were also used on Havana Fine and Hopewell vessels, it would show a continuance of rituals from the Middle Woodland to the Mississippian (Miller 2013). Dating sherds using burned on material and lipids could also provide evidence for a ceramic seriation that is almost impossible at the mixed context middens of the Central Illinois Valley.

An intensive study to determine the chronology at Ogden-Fettie would do much to advance the study of the Havana culture. The chronology of the site components at Ogden-Fettie is still unclear. A study with the goal of determining the age of the mounds at Ogden-Fettie would help in the understanding of floodplain mound centers. If my assumption about the Ogden-Fettie mounds age (Early Woodland or early Middle Woodland) is incorrect, then the function of $\mathrm{F}^{\mathrm{v}} 196$ will have to be reconsidered and probably revised.

These proposed research avenues could assist in testing the theories proposed about the Havana sites in the Central Illinois Valley.

- Winters suggested that Ogden-Fettie was the site of early social stratification and 
the high percentage of decorated sherds may represent offering vessels, though the faunal study did not support this.

- Determine if Ogden-Fettie and the Havana (Neteler) Mound were used by the same group of people and if the Havana culture was developed at the two mound centers.

The Ogden-Fettie mound center is a special site that has drawn people to it since its creation during the Early or Middle Woodland. Archaeological interest in the site began increasing rapidly during the late- $19^{\text {th }}$ and early- $20^{\text {th }}$ century leading to many of the mounds being excavated. These early excavations were focused on artifact recovery and not academic study, so little is known about the excavations. The interest by early amateur excavators has made site interpretation difficult, which is why few have attempted academic studies. The academic studies of $\mathrm{F}^{\mathrm{v}} 196$ have been the most fruitful, because for the most part the midden area was untouched. After analyzing the ceramic artifacts and comparing the collection with other sites, I believe $\mathrm{F}^{\mathrm{v}} 196$ was used as an Aggregation Site where groups gathered to practice rituals involving the mounds. The rituals practiced at Ogden-Fettie appear to be related to some of the earliest manifestations of the Havana culture. The early Havana people made drastically different technical choices when constructing their pottery, which shows that they were separated into distinct ceramic groups. Ogden-Fettie and the other Central Illinois Valley sites are difficult to study, but are rich with archaeological remains that provide an excellent opportunity for advancing the study of the Havana-Hopewell culture in Illinois. 


\section{REFERENCES}

Albrecht, Jessica

2013 Master's Thesis, Department of Sociology and Anthropology, Illinois State University, Bloomington, IL.

Asch, David L., Kenneth B. Farnsworth, and Nancy B. Asch

1979 Woodland Subsistence and Settlement in West Central Illinois. In Hopewell Archaeology: The Chillicothe Conference, edited by David S. Brose and N'omi Greber, pp. 80-85. Kent State University Press, Kent $\mathrm{OH}$.

Braun, David P.

1977 Middle Woodland- (Early) Late Woodland Social Change in Prehistoric Central Midwestern U.S. Ph.D. Dissertation, University of Michigan, Ann Arbor, MI.

Braun, David P., James B. Griffin, and Paul F. Titterington

1982 The Snyders Mounds and Five Other Mound Groups in Calhoun County, Illinois. University of Michigan, Museum of Anthropology, Technical Report 13.

Buikstra, Jane E.

1976 Hopewell in the Lower Illinois Valley: A Regional Approach to the Study of Human Biological Variability and Prehistoric Mortuary Behavior. Northwestern University Archaeological Program, Scientific Papers 2.

Buikstra, Jane E., Douglas K. Charles and Gordon F. M. Rakita

1998 Staging Ritual: Hopewell Ceremonialism at the Mound House Site, Greene County, Illinois, edited by Douglas K. Charles, Steven R. Leigh and Jane E. Buikstra. Kampsville Studies in Archaeology and History. Center for American Archaeology, Kampsville, Illinois.

Caldwell, Joseph R.

1964 Interaction Spheres in Prehistory. In Hopewellian Studies, edited by Joseph Caldwell and Robert Hall, pp. 135-156. State of Illinois, Springfield, IL. 
Cantwell, Anne Marie

1980 Dickson Camp and Pond: Two Early Havana Tradition Sites in the Central Illinois Valley. Illinois State Museum. Springfield, IL.

Charles, Douglas K., Steven R. Leigh and Jane E. Buikstra

1988 The Archaic and Woodland Cemeteries at the Elizabeth Site in the Lower Illinois Valley, edited by Douglas K. Charles, Steven R. Leigh and Jane E. Buikstra. Kampsville Archaeological Center Research Series. Center for American Archaeology, Kampsville, Illinois.

Cole, Fay Cooper and Thorne Deuel

1937 Rediscovering Illinois: Archaeological Explorations in and Around Fulton County. Chicago University Press. Chicago, Illinois.

Conrad, Lawrence A.

2004 Observations on the Occurrence of Middle Woodland Knife River Flint in Western Illinois. In Aboriginal Ritual and Economy in the Eastern Woodlands: Essays in Memory of Howard Dalton Winters, edited by Anne-Marie Cantwell, Lawrence A. Conrad, and Jonathan E. Reyman. Pp. 169-181. Illinois State Museum Scientific Papers vol. XXX, Illinois State Museum, Springfield, Illinois. Kampsville Studies in Archaeology and History, vol. 5, Center for American Archaeology, Kampsville, Illinois.

Crane, Horace Richard

1956 University of Michigan Radiocarbon Dates I. Science, New Series 124(3224):664-672.

Crane, Horace Richard and James B. Griffin

1958 University of Michigan Radiocarbon Dates. Science, New Series 128(3332):1117-1123.

Dillehay, Tom D.

1990 Mapuche Ceremonial Landscape, Social Recruitment and Resource Rights. World Archaeology 22(2): 223-241.

Epstein, Jeremiah F.

1951 A Statistical Stratigraphic Analysis of Ceramics from the Pool Site: A Hopewell Village in Illinois. Master's Thesis, University of Illinois. Champaign, IL.

Farnsworth, Kenneth B.

1986 Black Sand Culture Origins and Distribution. In: Early Woodland Archaeology, edited by Kenneth B. Farnsworth and Thomas E. Emerson. pp. 634-641. Kampsville Seminars in Archaeology vol. 2, Center for American Archaeology Press, Kampsville, IL. 
1990 Evidence for Specialized Middle Woodland Camps in Illinois. Illinois Archaeology. 2: 109-132.

Farnsworth, Kenneth B. and Ann L. Koski

1985 Massey and Archie: A Study of Two Hopewellian Homesteads in the Western Illinois Uplands. Kampsville Archaeology Center. Research Series 3. Center for American Archaeology Press. Kampsville, IL.

Farnsworth, Kenneth B. and David L. Asch

1986 Early Woodland Chronology, Artifact Styles and Settlement Distribution in the Lower Illinois Valley Region. In: Early Woodland Archaeology, edited by Kenneth B. Farnsworth and Thomas E. Emerson. pp. 326-448. Kampsville Seminars in Archaeology vol. 2, Center for American Archaeology Press, Kampsville, IL.

Farnsworth, Kenneth B., Thomas E. Berres, Randall E. Hughes, and Duane M. Moore 2004 Illinois Platform Pipes and Hopewellian Exchange: A Mineralogical Study of Archaeological Remains. In: Aboriginal Ritual and Economy in the Eastern Woodlands. Essays in Memory of Howard D. Winters edited by Anne Marie Cantwell, L. A. Conrad, and J. E. Reyman pp. 182-214. Illinois State Museum Scientific Papers 30, Springfield, IL.

Farnsworth, Kenneth B. and Michael D. Wiant

2006 Illinois Hopewell and Late Woodland Mounds. The Excavations of Gregory Perino 1950-1975. Illino is Transportation Archaeological Research Program, Studies in Archaeology 4. University of Illinois, Champaign-Urbana.

Fie, Shannon M.

2006 Visiting in the Interaction Sphere: Ceramic Exchange and Interaction in the Lower Illinois Valley. In Recreating Hopewell. edited by Douglas K. Charles and Jane E. Buikstra. pp. 427-455. University of Florida, Gainesville, FL.

Fortier, Andrew C.

2004 The Petite Michele Site. Illinois Department of Transportation Department of Anthropology University of Illinois Urbana-Champaign. Champaign, IL.

1989 The Holding Site: A Hopewellian Community in the American Bottom. Illinois Department of Transportation Department of Anthropology University of Illinois Urbana-Champaign. Champaign, IL. 
Fowler, Melvin L.

1952 The Clear Lake Site: Hopewellian Occupation. In: Hopewellian Communities in Illinois, edited by Thorne Deuel pp. 131-176. Illinois Museum, Scientific Papers 5. Springfield, IL.

Griffin, James B.

1952 Some Early and Middle Woodland Pottery Types in Illinois. In:

Hopewellian Communities in Illinois, edited by Thorne Deuel pp. 93-129. Illinois Museum, Scientific Papers 5. Springfield, IL.

1959 The Chronological Position of the Hopewellian Culture in the Eastern United States. Anthropology Papers No. 12, Museum of Anthropology, University of Michigan. Ann Arbor, MI.

1970 The Burial Complexes of the Knight and Norton Mounds in Illinois and Michigan. University of Michigan, Museum of Anthropology, Memoir 2.

1979 An Overview of the Chillicothe Conference. In Hopewell Archaeology: The Chillicothe Conference, edited by David S. Brose and N'omi Greber, pp. 80-85. Kent State University Press, Kent OH.

Harn, Alan D.

1986 The Marion Phase occupation of the Larson Site in the Central Illinois Valley. In: Early Woodland Archaeology, edited by Kenneth B.

Farnsworth and Thomas E. Emerson pp. 244-278. Kampsville Seminars in Archaeology vol. 2, Center for American Archaeology Press, Kampsville, IL.

Hayden, Brian

2003 Shamans, Sorcerers, and Saints: The Prehistory of Religion. Smithsonian Institution Press: Washington, DC.

Hennessey, John

1988 An Analysis of a Specialized Lithic Industry from Ogden-Fettie, 11-Fv197 Fulton County, Illinois. Master's Thesis, Department of Anthropology. New York University, New York.

Henriksen, Harry C.

1957 Utica Hopewell, A Study of Early Hopewellian Occupation in the Illinois River Valley. Master's Thesis. University of Illinois Urbana Champaign, Urbana-Champaign, IL. 
Holt, Julie Z.

2000 Animal Exploitation and the Middle to Late Woodland Transition: A

Comparison of Animal Use at Mound Centers and Hamlets in the Lower and Central Illino is Valleys. Ph.D. Dissertation. Department of Anthropology, New York University.

Liu, Chao Li, Dennis D. Coleman, David L. Asch, and B. W. Fisher

1992 Illinois State Geological Survey Radiocarbon Dates VI. Radiocarbon 34(1):83-104.

Maher, Thomas O.

1989 The Middle Woodland Ceramic Assemblage. In The Holding Site: A Hopewellian Community in the American Bottom. Edited by Andre C. Fortier, pp. 125-318. Illino is Department of Transportation Department of Anthropology University of Illinois Urbana-Champaign. Champaign, IL.

Martin, Montana L.

2013 Havana Hopewell's Relationship Status: The Relationship Between Ceremonial Pottery and Distance from Mound Centers, 250 BC- AD 200. Poster presented at Illinois State University 2013 Research Symposia, Bloomington, IL.

Marx, Karl and Friedrich Engels

1848 The Communist Manifesto. Translated by Samuel Moore 1888, Penguin Group, London.

McCarthy, John and Helen Chambly

1976 Topographic Map. Unpublished on file at Illinois State Museum: Dickson Mounds Branch. Lewiston, IL.

McGregor, John C.

1952 The Havana Site. In: Hopewellian Communities in Illinois, edited by Thorne Deuel, pp. 45-91. Illinois Museum, Scientific Papers 5. Springfield, IL.

1958 Pool and Irving Villages: A Study of Hopewell Occupation in the Illinois River Valley. University of Illino is Press, Urbana, IL.

Meinkoth, Michael C.

1995 The Sister Creeks Site Mounds. Illinois Department of Transportation Department of Anthropology University of Illinois Urbana-Champaign. Champaign, IL. 
Miller, Jessica R.

2013 Evidence of Ritual Drink Preparation and the Function of Powell Plain and Ramey Incised Vessels in Mississippian Society. Master's Thesis, Department of Sociology and Anthropology, Illinois State University, Bloomington, IL.

Morgan, David T.

1985 Ceramic Analysis. In Smiling Dan: Structure and Function at a Middle Woodland Settlement in the Illinois Valley, Kampsville Archaeological Center, Research Series 2:183-257. Center for American Archaeology Press, Kampsville IL.

1986 Ceramics. In Woodland period occupations of the Napoleon Hollow site in the lower Illinois valley, edited by Michael D. Wiant and Charles R. McGimsey. Kampsville Archaeological Center, Research Series 6: 364426. Center for American Archaeology Press, Kampsville IL.

Morse, Dan F.

1963 The Steuben Village and Mounds: A Multicomponent Late Hopewell Site in Illinois. Anthropological Papers, No. 21. Museum of Anthropology, University of Michigan, Ann Arbor, MI.

Munson, Patrick J.

1967 A Hopewellian Enclosure Earth Work in the Illinois River Valley. American Antiquity 32(3):391-392.

1982 Marion, Black Sand, Morton, and Havana Relationship: An Illinois Valley Perspective. Wisconsin Archaeologist 63(1):1-17.

1986 Black Sand and Havana Tradition: Ceramic Assemblage and Culture History in the Central Illino is River Valley. In: Early Woodland Archaeology, edited by Kenneth B. Farnsworth and Thomas E. Emerson pp. 280-298. Kampsville Seminars in Archaeology vol. 2, Center for American Archaeology Press, Kampsville, IL.

Munson, Patrick J. and Alan D. Harn

1966 Surface Collections from Three Sites in the Central Illinois River Valley. Wisconsin Archaeologist 47:150-168.

Renfrew, Collin

1976 Megaliths, Territories, and Populations. In Acculturation and Continuity in Atlantic Europe, edited by Sigfried J. De Laet. Dissertationes Archaeologicae Gandenses. 
Ruby, Bret J., Christopher Carr and Douglas K. Charles

2006 Community Organizations in the Scioto, Mann, and Havana Hopewellian Regions: A Comparative Perspective. In Gathering Hopewell: Society, Ritual, and Ritual Interaction, edited by Christopher Carr and Troy D. Case, pp. 119-176. Springer Publishing, New York.

Seeman, Mark F.

1979 The Hopewell Interaction Sphere: The Evidence for Interregional Trade and Structural Complexity. Prehistory Research Series 5(2). Indiana Historical Society, Indianapolis, IN.

Sheilds, Wane F.

n.d. The Ogden-Fettie Site: An Archaeographic Compendium. Unpublished Manuscript on file at Illinois State Museum: Dickson Mounds Branch. Lewiston, IL.

Shetrone, Henry C.

1930 The Mound Builders. D. Appleton and Company, New York.

Skibo, James M.

2012 Understanding Pottery Function. Springer, New York.

Smith, Bruce D.

1992 Hopewellian Farmers of Eastern North America. In Rivers of Change, by Bruce D. Smith, pp. 201-208. Smithsonian Institution Press, Washington, D.C.

Staab, Margie L.

1984 Peisker: An Examination of Middle Woodland Site Function in the Lower Illinois Valley. Ph.D. Thesis. Department of Anthropology, University of Iowa.

Stafford, Barbra and Mark B. Sant

1985 Smiling Dan: Structure and Function at a Middle Woodland Settlement in the Illinois Valley. Center for American Archaeology, Research Series 2.

Kampsville Archaeological Center, Kampsville IL.

Stevens, Alden

1931 University of Chicago Notes, Lewiston, IL. (Cited by Sheilds n.d.).

Stretton, Sean C.

2013 The Importance of Time: Examining the Expansion of Middle Woodland Havana Materials into the Grand River Valley of Western Michigan. Master's Thesis, Department of Sociology and Anthropology, Illinois State University, Bloomington, IL. 
Struever, Stuart

1960 The Kamp Mound Group and a Hopewell Mortuary Complex in the Lower Illinois Valley. Master's Thesis, Northwestern University.

1964 The Hopewellian Interaction Sphere in Riverine Western Great Lakes Culture History. In Hopewellian Studies, edited by Joseph R. Caldwell and Robert Hall, pp. 85-106. State of Illinois, Springfield, IL.

1968a A Re-Examination of Hopewell in Eastern North America. Ph.D. Dissertation, Department of Anthropology, The University of Chicago, Chicago.

1968b Woodland Subsistence-Settlement Systems in the Lower Illinois Valley. In New Prespectives in Archaeology, edited by Lewis Binford and Sally Binford, pp. 285-313. Aldine, Chicago, IL.

Struever, Stuart and Gail L. Houart

1972 An Analysis of the Hopewell Interaction Sphere. In: Social Exchange and Interaction. edited by Edwin M. Wilmsen. pp. 47-79. Anthropology Papers 46. University of Michigan. Ann Arbor, MI.

Styles, Bonnie W. and James R. Purdue

1986 Middle Woodland Faunal Exploitation. In Woodland period occupations of the Napoleon Hollow site in the lower Illinois valley, edited by Michael D. Wiant and Charles R. McGimsey. Kampsville Archaeological Center,, Research Series 6: 513-526. Center for American Archaeology Press, Kampsville IL.

Taylor, Jay L.B.

1929 Appendix B- Some Researches in the Illinois River Valley Near Havana. In The Cahokia Mounds. edited by Warren K. Moorehead and Jay L.B. Taylor. pp. 155-166. Bulletin Series XXVI. University of Illinois, Urbana, IL.

Wettersten, Vernon $\mathrm{H}$.

1960 Ceramic Analysis of a Hopewell Village. Unpublished manuscript.

Wiant, Michael D. and Charles McGimsey

1986 Woodland Period Occupations of Napoleon Hollow Site in the Lower

Illinois Valley. Center for American Archeology, Kampsville Archeological Center Kampsville, IL. 
Winters, Howard D.

1981 Excavating in Museums: Notes on Mississippian Hoes and Middle Woodland Copper Gouges and Celts. In The Research Potential of Anthropological Museum Collections, edited by Anne-Marie E. Cantwell, James B Griffin and Nan A. Rothschild, pp. 17-34. Annals of the New York Academy of Science, vol. 376. New York American Academy of Sciences, New York.

Winters, Howard D.

n.d. Pottery Tabulation from the 1985 Ogden-Fettie Excavations.

Wray, Donald E. and Richard S. MacNeish

1961 The Hopewellian and Weaver Occupations of the Weaver Site, Fulton County, Illinois. Scientific Papers, Vol. VII(2). Illinois State Museum, Springfield, IL. 
APPENDIX

TYPOLOGY 
This typology is a reorganization and integration of the typology presented in Griffin (1952). It has been modified with more recent studies and has tailored to fit the Ogden-Fettie collection. The typology was made more specific, but there is a lot of room for improvement; as there was great variability in size of decorations and the application technique, which could have signified different decoration types. The use of decoration variables was not used because of time constraints. Many of the decoration styles are used in multiple series, the decorations are described under the pottery series they were most commonly applied to at Ogden-Fettie.

Black Sand Series (Appendix A: a-d; Appendix D: g) is some of the earliest pottery present at Ogden-Fettie. It is generally black or dark in color and is made with well mixed grit temper. The sherds are cordmarked and occasionally decorations are applied over the cordmarking. The relationship between Black Sand and Havana pottery is not clear; however, there are Havana sherds with Black Sand Incising (Farnsworth and Asch 1986; Farnsworth 1986). The pottery consists of sherds decorated with Black Sand Incising and Liverpool Cordmarking.

Liverpool Cordmarked (Appendix A: a) is the cordmarked Early Woodland body sherds exhibiting a Black Sand paste and temper. They often are accompanied by Black Sand Incised.

Black Sand Incised (Appendix A: a and b) is a style of decoration that is usually applied to a cordmarked pottery surface. Lines are incised on the pottery by pressing and dragging a tool across the surface of pottery. The lines are usually rowed and meet other rowed lines at various angles. Chevrons are common Black Sand Incised patterns. 
Black Sand Sherds

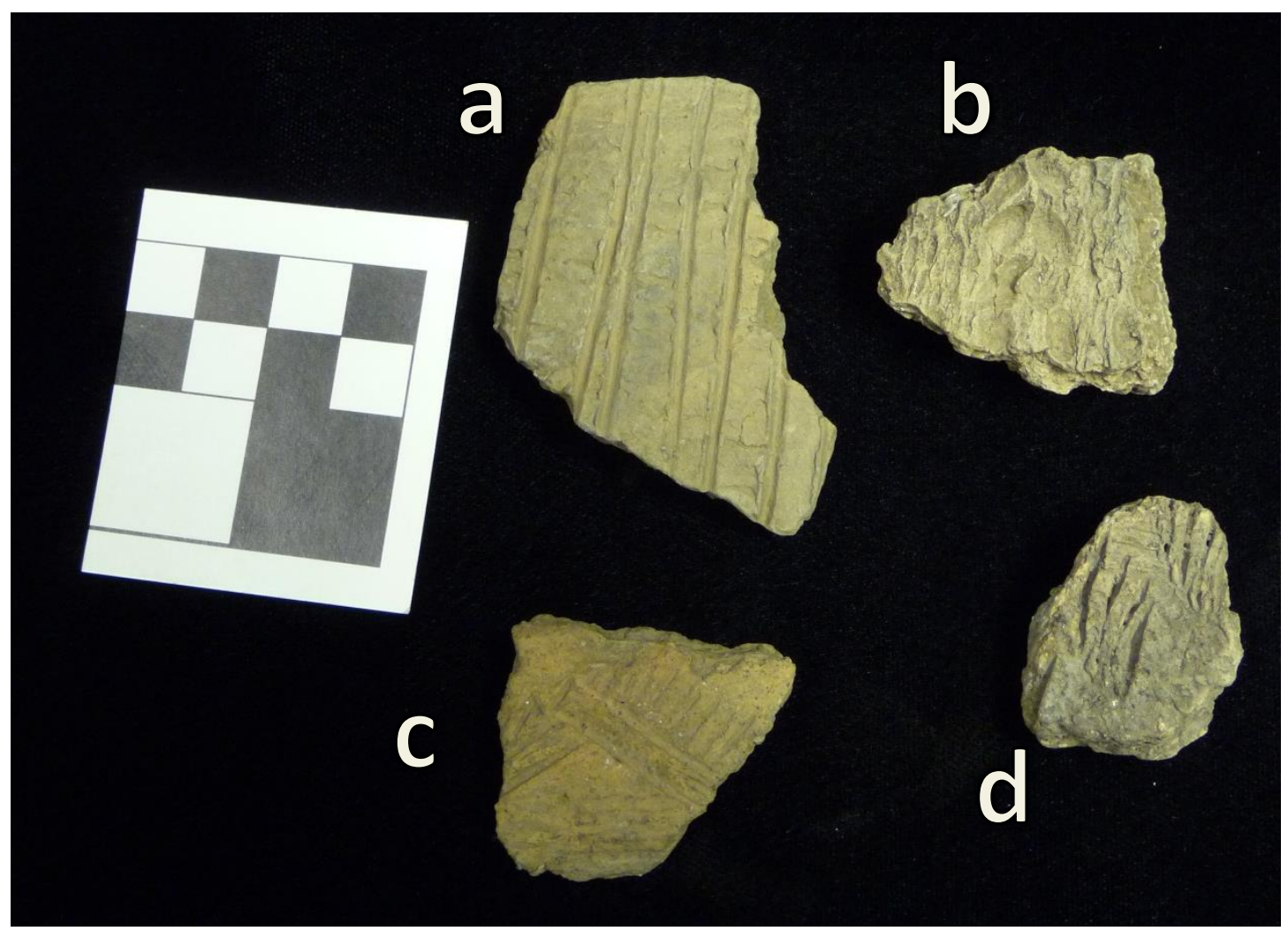

Black Sand sherds. (a) Black Sand Incised sherd (b) Sister Creek Punctate (c) Black Sand Incised Chevron (d) Unnamed Decoration (Collection of Illinois State Museum).

Sister Creeks Punctate (Appendix A: b) as described by Griffin (1952) can take many forms including annular, cylindrical, fingernail, and pinched. This is an almost all inclusive category, which creates confusion when the name is applied. Sister Creeks Punctates can be applied to Black Sand and early Havana pottery. Sister Creeks Punctates can be applied to smoothed or cordmarked surfaces and are often seen in conjunction with incised lines. The Sister Creeks Punctates are usually used to form a 
Chevron pattern. This research expanded the category to help identify the differences in decorations, but was unable to advance the category much because of insufficient sherd totals.

Sister Creek Circular or Annular Punctates are the circular impressions left by a hollow stick pressed into a pots wall. Often a small Cylindrical Punctate will appear in the center of the Annular Punctate. The Annular Punctate may be the plain variety of the Neteler Circle, but future research is necessary to understand the relationship (Griffin 1952).

Sister Creek Cylindrical Punctates are the impressions left by pressing a solid rounded tool into the exterior of a vessel. The impressions are a circular divot.

Fingernail and Pinched Punctates are created by pressing fingernails or a similar tool into the exterior of the pot or by pressing fingers into the pot and pinching up the clay (Griffin 1952). This group is fairly rare at Ogden-Fettie; future research might reveal that it is necessary to separate the two techniques. Peisker pinched is a related lower valley style (Farnsworth and Asch 1986).

Early Havana Series (Appendix D: a-c, h-t) is made up of the early forms of Havana pottery decoration. Most decorations are also used on Havana Series. The pottery is fairly thick with poorly mixed grit temper and usually has nodes near the rim (Griffin 1952). early Havana decorations are usually applied to a smooth or smoothed surface, but have been identified on smoothed over-cordmarked surfaces.

Morton (Appendix D: a-c, h) is an early manifestation of the Havana Tradition. The pots can have a poor to very fine construction, which makes classification tough. It 
also has many of the same attributes of Black Sand Incised, as decorations are usually over cordmarking (Griffin 1952). Morton also shares many decorations with later Havana pottery. The similarities between the three types of pottery shows a direct evolutionary line from Black Sand to Havana, contrary to what Munson (1986) said in his article The Black Sand and Havana Traditions.

Morton Incising (Appendix D: a)very similar to Black Sand Incising lines are usually in $\mathrm{V}$ or $\mathrm{U}$ shaped herringbone patterns, but can occur in other designs (Baker et al. 1941; Cantwell 1980; Cole and Deuel 1937; Epstein 1951).

Fettie Neck Band (Appendix D: b) is the later form of Morton designs; it is a design that is applied to the neck of a vessel to just under the lip (Wray and MacNeish 1961). The designs used include incised lines, punctates, and crescents. Neck Band designs also occur on Havana vessels, furthering the link between Havana and Morton vessels. A Neck Band on Havana vessels is known as a Havana Neck Band.

Fettie Chevrons (Appendix D: c, g) were defined by Cantwell (1980) as being incised lines meeting at various angles creating a chevron shape, but they can also be made using punctates or stamps. Chevrons are an early design style that is common on Morton, Fettie, Sister Creek, and some Havana sherds

Neteler Stamped (Appendix D: i-o, q, r, t) is similar to Naples Stamped mentioned later, however it uses sections of a circular tool to create a stamp rather than a straight bar stamp (Epstein 1951; Griffin 1952).

Neteler Crescents (Appendix D: i-o, q, $\mathrm{r}, \mathrm{t}$ ) are the most common Neteler Stamp. It is created by a tool that is approximately half of a circle and can be dentate or plain. 
They can be applied in both in the lower case $\mathrm{u}$ and in the lower case $\mathrm{n}$ and sometimes in an alternating $\mathrm{u}$ to $\mathrm{n}$ pattern. They can be used in vertical, horizontal, and sometimes diagonal rows, and in conjunction with zoning lines, and can be used as alternation between $u$ and $n$ directions (Griffin 1952).

Neteler Half Crescent (Figure 17) is a strange variant of the Neteler Crescent where the crescent appears to have broken and just half is used to apply a half crescent. It was seen on a single rim sherd from Ogden-Fettie.

Neteler Circle is similar to Neteler Crescents, except it makes a full circle. It has been seen in the photo log from the Jay L.B. Taylor excavations of mound the mound fill pile from $\mathrm{F}^{\mathrm{o}} 175$ and in Farnsworth and Wiant (2006): 155f. There is a pot with a Fettie Neck band of Neteler Circles from the Norton Mounds in Michigan. This decoration was previously considered part of the Sister Creek Punctate family (Farnsworth and Wiant 2006; Griffin 1952).

Hummel Crescent (Appendix D: p, s) is very similar to Neteler Crescents and can easily be confused. The definition of Hummel Crescents has changed since Griffin (1952) where it was pictured as half a Rocker Dentate (mentioned later). Today Hummel Crescents are defined by their slight crescent shape that appears as a toadstool in profile view. The ends of the Hummel Crescent stamp are rounded and appear to be made by a different tool than the Neteler Crescent. They have been noted on Morton pottery and Havana pottery, but seem to be confined to the early days of the Havana tradition (Farnsworth and Wiant 2006: 157). 
Havana Series (Appendix D: u-nn, ww-zz) pottery was defined at Ogden-Fettie as thick sherds with large and unevenly mixed grit temper exhibiting Havana decorations. A few Havana sherds are thin with evenly mixed temper, but they still exhibit characteristic Havana sherds. Most Havana vessels have medium to large orifice diameters and exhibit a beveled rim that usually slopes to the center of the vessel (Epstein 1951). Nodes are also common on Havana rim sherds. Havana pottery can have a variety of decorations including cordmarking, stamping, punctates, nodes, cord wrapped stick, incising, smoothed, and shaving; it was also found to exhibit Morton-Fettie designs. The Havana pots are usually decorated in a band near the rim (Griffin 1952). Before decorations were applied, the area that was to be decorated was usually smoothed to a plain surface.

Nodes were not considered a decoration, because they are applied to almost all vessels and do not require a specially smoothed zone for application. The nodes are created by pressing a stick into the interior of a pot until the wall of the pot protrudes out the other side. Nodes were measured to ascertain if a relationship between Node size and sherd thickness existed.

Cordmarked, Smoothed Over Cordmarking, and Smoothed Havana (Appendix D: ww-zz) sherds exhibiting Havana paste and temper and having surface treatments of cordmarking, smoothed cordmarking, or smoothed plain surface treatment. They are the most common sherds at Havana sites, including Fv196 (Cole and Deuel 1937; Epstein 1951; Griffin 1952; Morgan 1985). Some of the Havana pots were initially vertically cord marked and then areas were smoothed for applying the decorations (Epstein 1951; 
Griffin 1952). But as time wore on pots became produced completely smooth. In the Central Illinois Valley smoothed Havana sherds are the most common.

Havana Neck Band is almost identical to a Fettie Neck Band, but instead it is applied to a Havana Vessel and is usually seen on early Havana Vessels and is probably a remnant of the transition from Morton techniques to Havana.

Naples Stamped (Appendix D: u-11) is a very common design on Havana vessels and sometimes occurs on Hopewell vessels. Naples Stamped comes in a multitude of varieties Naples Ovoid Stamp, Naples Plain Stamp, Naples Dentate Stamp, and Naples Cordwrapped Stick Dentate varieties. To make a Naples Stamp the stamp is pressed into a vessels surface, while the surface is still plastic. The pressing is usually applied to a smoothed surface, however on some rare occasions it can be done on a cordmarked surface (Epstein 1951; Griffin 1952). Naples Stamped is usually applied in horizontal or vertical rows, and is most commonly placed on the outer surface, but can also occur on the lip and inner rim of vessels. This research does not consider the Hummel variety laid out in Griffin (1952) as being a curved Naples Stamp, because the curve appears to be an application technique that is subjectively classified. Even in Griffin (1952) there are pictures of sherds that under his guidelines could be classified as Hummel (109), but were called Naples Stamped. As such all Hummel Stamped will be classified under one of the Naples varieties.

Naples Ovoid Stamp is similar to the other Naples stamps, however it has rounded edges. Ovoid Stamps can be plain, dentate, or cross hatched (Epstein 1951; Griffin 1952). Large Ovoid Stamps appear to be indicative of early Havana Tradition, all Ovoid 
Stamps stop being used fairly early in the Havana tradition.

Naples Plain Stamp is a variety of Naples Stamp that uses a plain bar in horizontal or vertical lines. According to Griffin (1952) Naples Plain is rare; accordingly the analysis of Ogden-Fettie material has yielded a few examples.

Naples Dentate Stamp (Appendix A: e; Appendix D: u-hh) is the most common decoration applied to Havana pottery (Griffin 1952). It is created by pressing a stamp that has been modified to have teeth into the pot, to create a series of peaks and valleys similar to tooth marks. Naples Dentate Stamp can come be very thick to very fine, but this study did not differentiate between the thicknesses of the decoration. Braun (1977) noted that Naples Dentate Stamps appear to decrease over time, probably as a result of decreasing sherd thickness. At $\mathrm{F}^{\mathrm{v}} 196$ fine Naples Stamps were applied to thick and thin pottery, while the thick stamps were only applied to thick sherds.

\section{Havana Sherd}

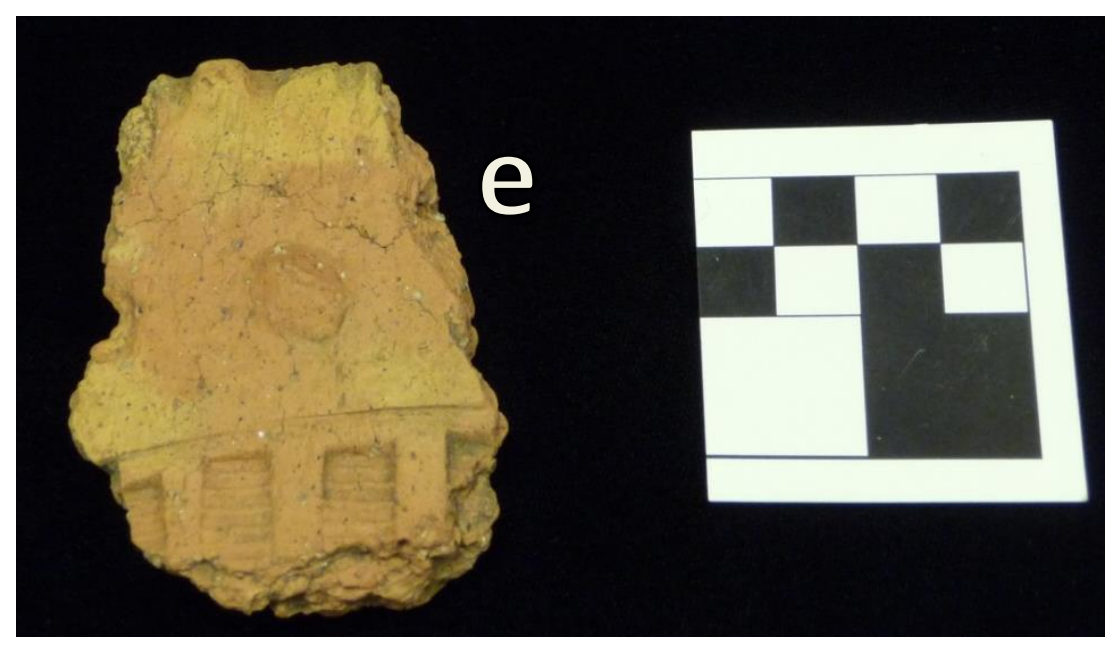

Havana sherd with Naples Dentate and nodes (Collection of Illinois State Museum). 
Cordwrapped Stick Dentate (Appendix D: ii, kk) is a stamp that is extensively used nearing the end of the Havana culture (Braun 1977). It is used in many of the same contexts as Naples Dentate Stamping.

Rocker Stamp (Appendix D: mm, nn) is an application technique that uses Naples Stamps. The stamp is pressed into the sherd and then rocked side to side walking across the face of the sherd. This technique is used with all forms of Naples Stamps. The Cordwrapped Stick variety can easily be confused with drag rocker decorations seen at other Middle Woodland sites.

Steuben Punctate is defined by Griffin (1952) as being a punctate or impression on the pottery surface, usually having a hemiconical shape. They are often in vertical rows giving them a similar appearance to dentate stamps. At Ogden-Fettie Steuben Punctate is rare and is seen on only a few sherds. The design usually manifests itself as a singular horizontal row applied to the neck of vessels at $\mathrm{F}^{\mathrm{v}} 196$ (Griffin 1952).

Zoning (Appendix D: ee, hh, ii-1l) is a decoration created by dragging a tool across the surface of the pot to create a line used to separate decoration areas. Zoning lines have a variety of thicknesses and application tools (Epstein 1951; Griffin 1952). Some zoning lines appear to use a square tool that leaves a flat bottomed square edged zoning line. While other zoning lines were created using a tool with a rounded bottom, similar to the one used to create a Cylindrical Punctate, although some varieties may have been created by fingers.

Havana-Pike at Ogden-Fettie $\mathrm{F}^{\mathrm{v}} 196$ was rare and only made up a small percentage of the total sherds. It was defined by the presences of Havana paste and 
temper, but also the Baehr brushing surface treatment that is normally associated with Pike and Baehr vessels.

Havana Fine (Appendix A: f-i; Appendix D: oo, pp) is pottery from Ogden-Fettie that exhibits Havana paste and temper, but is a much finer sherd. Staab (1984) identified this pottery, but she labeled it Hardin Ware (McGregor 1952). Her definition was ambiguous and could have been applied to pottery created during the transition period between Early Woodland and Middle Woodland or during the Middle Woodland to Late Woodland transition. I have defined the sherds as appearing only during the early days of Havana. The sherds have Havana paste and temper, at Ogden-Fettie they were generally grit tempered, although there were 21 shell tempered sherds. Shell tempered Havana Fine ceramics are only seen at the Havana Mounds and Ogden-Fettie. The paste is fine grained with occasional Mica flake inclusions. They are generally thinner, two to seven millimeters, and more finely and highly decorated. Havana Fine wares also exhibit burnishing and have smaller orifice diameters than Havana vessels (less than $20 \mathrm{~cm}$ diameter). Braun et al. (1982) mentions a sherd excavated from Snyders Mound Co 104 matching the Havana Fine category, but the sherd came from a mound fill context, there are also examples from Havana, Peisker, Utica, Norton, and others (Griffin et al. 1977; Henriksen 1957; McGregor 1952; Staab 1984; Wettersten 1960). 
Havana Fine Sherds

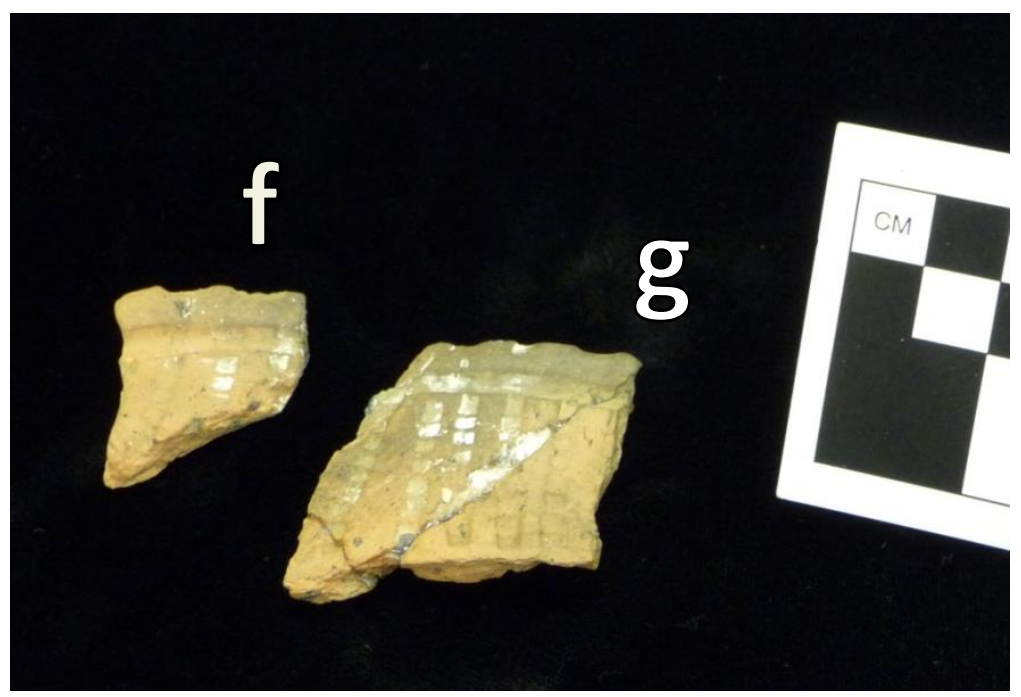

Havana Fine sherds (f, g) Havana Fine sherds decorated with Naples Dentate and Havana Zoned (Collection of Illinois State Museum).

Havana Fine Sherds

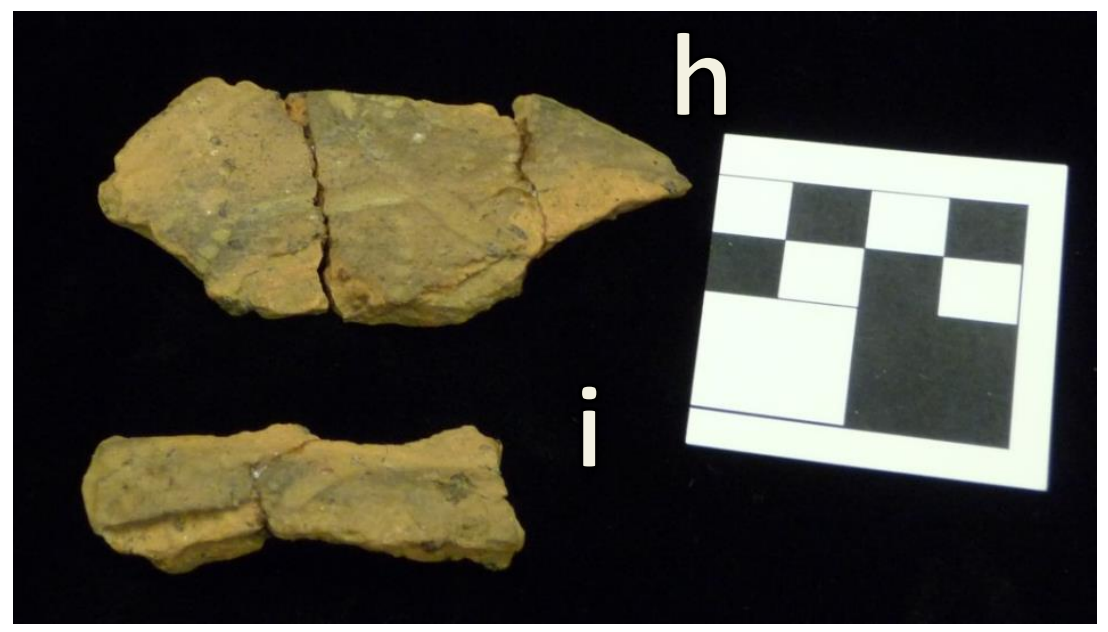

Havana Fine sherds from 1959 Excavation $(h, i)$ shoulder of a bowl exhibiting visible mafic temper and decorated with Naples Dentate and Havana Zoning (Collection of Illinois State Museum). 
Havana Flat Bottom as the name suggests is a vessel with Havana paste, temper, and a flat bottom. Havana Flat Bottomed vessels are usually found in mortuary contexts (McGregor 1952). Havana Flat Bottom is rare and only occurs on Havana Fine pots. The other Middle Woodland pots with flat bottoms come from Hopewell vessels allowing them to sit on many different surfaces. Middle Woodland pottery with a flat bottom is an indicative of a special/ritual function.

Havana Shell is Havana pottery with the presence of shell tempering. The shell temper appears to be from snail shells rather than mussel shell as with Mississippian pottery. There are 20 shell tempered Havana sherds from Ogden-Fettie, including one rim sherd with a beveled rim, nodes, and Naples Dentate Stamping. The shell temper may be an oddities or a local tempering tradition. The Havana Shell sherds were finely made and small, and are included in the Havana Fine category.

Hopewell Series (Appendix A: j-n; Appendix D: qq-vv) sherds are thin and finely made pottery with grit, limestone, or sand temper. Hopewell sherds are finely decorated and constructed. Hopewell Series is believed to be used for ceremonial purposes, because it appears in association with ritual objects and burials (Farnsworth personal comm.; Struever 1968b; Morgan 1985; Morgan 1986). Undecorated thin finely made sherds with grit or sand temper considered type indeterminate because of the potential for misclassification of Weaver pottery. Undecorated finely made limestone sherds are classified as Baehr/Hopewell, while thicker limestone sherds were put into the Pike category (Griffin 1952). 


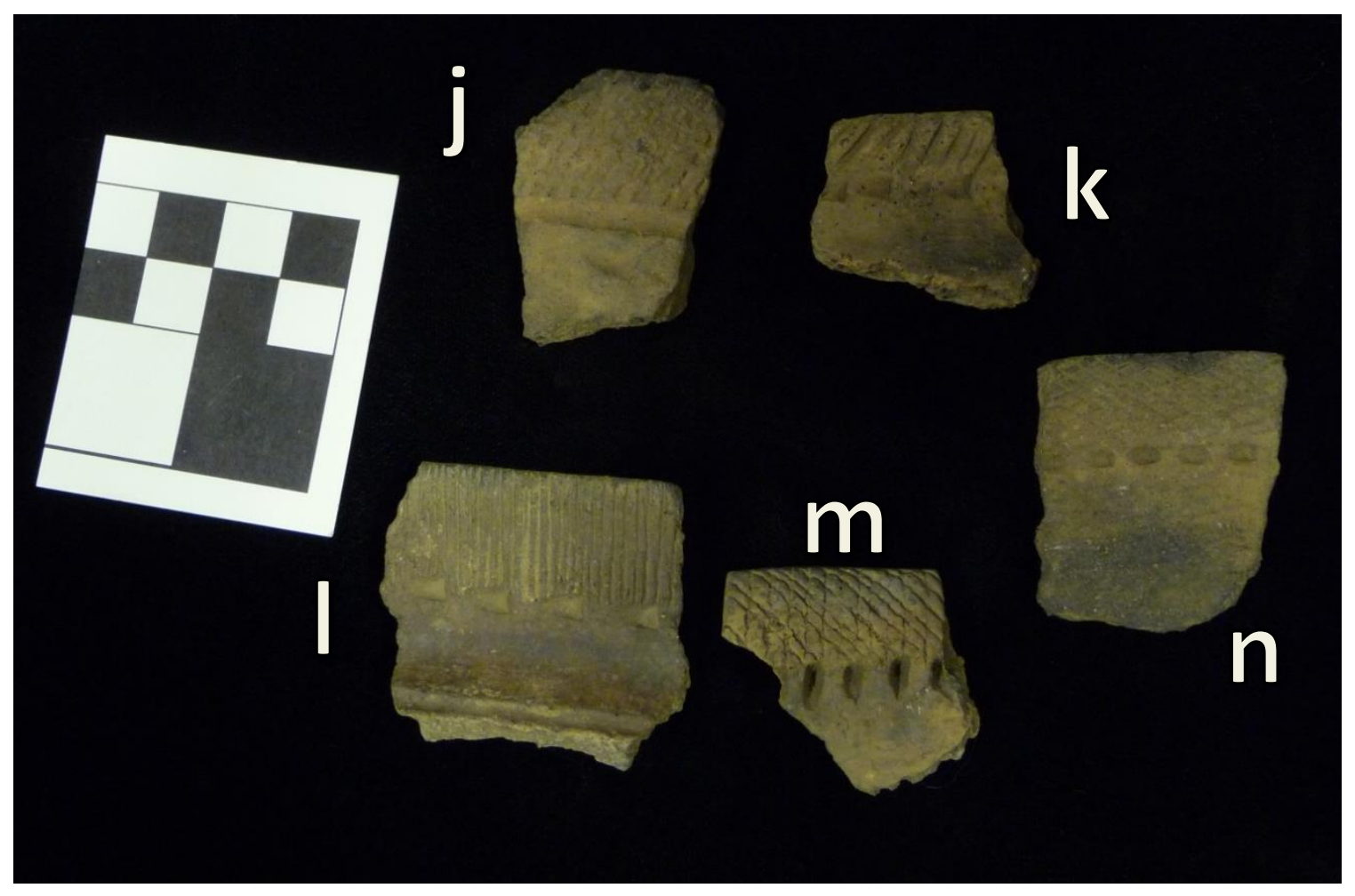

Hopewell sherds: (j) Hopewell Stamped Rim decorated with Hopewell Zoned and Hopewell Punctate (k) Hopewell Stamped Rim decorated with Hopewell Punctates (1) Hopewell Incised Rim decorated with Hopewell Zoned and Hopewell Punctates (m) Hopewell Crosshatched Rim decorated with unnamed punctates (n) Hopewell Crosshatched Rim decorated with unnamed punctates (Collection of Illinois State Museum).

Montezuma Punctate (Appendix D: uu) is a strictly Hopewell punctate that is applied in rows to create a rim or neck band. Montezuma Punctate is created by pressing a finger into an unfired pot. The decoration is never used in conjunction with other decorations. 
Hopewell Punctate (Appendix A: k, l) is a punctate similar to Montezuma, except it is created by pressing a stick into an unfired pot. Hopewell Punctate usually applied in a single horizontal row and is used to separate the rim from the lower portions of a Hopewell vessel (Epstein 1951; Griffin 1952). Appendix A: $m, n$ is an unknown punctate applied in the same manner as a Hopewell Punctate and probably represent a variation of the decoration type.

Hopewell Rocker Plain similar to the dentate variety except it uses a plain stamp. The two could be combined because plain rockering is not common at Ogden-Fettie.

Hopewell Zoned (Appendix A: j, 1; Appendix D: qq-tt, vv) is similar to Havana Zoned, except it exhibits much finer zoning. It is usually used to separate decorated zones from undecorated zones.

Hopewell Zone Red Filmed is a technique where a pot is zoned and then a red film is applied to one or rarely both zones (Griffin 1952).

Hopewell Incised (Appendix D: vv) is a decoration created by incised lines, similar to incised rims.

Naples Stamped Hopewell Variety (Appendix D: ss, tt) is the fine Hopewell variety of the Naples Stamped category.

Hopewell Rocker Dentate is an application technique that creates a series of zigzagging curved dentate. The tool used is probably the same as is used in the creation of Naples Fine Dentate (Epstein 1951). 
Hopewell Plain is a Hopewell sherd with no decoration. These sherds can come from anywhere on the pot, because empty space was employed in all areas of Hopewell pots.

Hopewell Crosshatched Rim (Appendix A: m, n) is a technique applied to the exterior rim of a Hopewell vessel. It is created by making fine incised lines that intersect to create a crosshatched appearance (Epstein 1951; Griffin 1952).

Hopewell Incised Rim (Appendix A: 1) is similar to the crosshatched rim, but it uses a series of vertically incised lines to create a rim decorated.

Hopewell Stamped Rim (Appendix A: j, k) is a stamped manifestation of the crosshatched rim, usually is applied in vertical rows and can be created with plain or dentate varieties.

Brangenburg is a rim style that has a characteristic T-shaped rim (Griffin 1952). They are often accompanied by a single row of horizontal Hopewell Punctate. Brangenburg

Baehr Series sherds are thin finely made limestone tempered sherds that exhibit Baehr brushing or incised lines (Griffin 1952). There were no limestone tempered Baehr sherds at Ogden-Fettie, but some Baehr brushed grit tempered sherds were present. The grit tempered sherds were included in the Baehr series. Baehr seems to be the later manifestation of ceremonial pottery (Morgan 1985; Morgan 1986).

Baehr Brushed is characteristic of Baehr or Pike pottery. Baehr Brushed is created by brushing the surface of a pot during production. The vessel is usually completely brushed an exhibits long brush strokes (Epstein 1951). 
Pike Series sherds are usually defined as thick limestone sherds, with Baehr Brushing and incised lines (Farnsworth personal comm.; Griffin 1952). Grit tempered thick sherds with Baehr brushing were categorized as Havana-Pike. Havana-Pike was included under the Havana series, because its presence was very small.

Middle Woodland Type Indeterminate is the sherds that fit most of the criteria for the various Middle Woodland Categories. Many of the sherds that are delaminated and only show an interior surface fit into this category.

Weaver sherds were defined as medium to fine grit tempered pottery, that can be smoothed, nodded, cord marked, and among other surface treatments (Griffin 1952). Weaver pottery at Ogden-Fettie appears to have a higher firing temperature than Havana pottery based upon an exterior color change and the sound the sherds make when tapped. Firing temperature change is based upon observations and not testing, so it is an unproven theory. Weaver pottery can be easily confused with Havana Fine sherds.

Mississippian pottery is defined by the presence of mussel shell tempering usually accompanied by cordmarking.

Notes:

Many of the pottery types listed were previously defined by Griffin (1952) and others. There is more variation that was not feasible to quantify in the limited scope of a Master's Thesis, but future research could expand the typological categories to include more decorations. 
APPENDIX B

SHERD TOTALS BY EXCAVATION 


\begin{tabular}{|l|l|}
\hline Type & Number of Sherds (Percent of Total) \\
\hline Havana Havana Decorated & $716(91 \%)$ \\
\hline Hopewell & \\
\hline Havana Fine & $36(4.5 \%)$ \\
\hline
\end{tabular}

1: 1959 Surface Collection

\begin{tabular}{|l|l|l|l|l|}
\hline Type & TT\#1 & TT\#3 & TT\#5 & TT\#6 \\
\hline Havana & $101(96 \%)$ & $11(73 \%)$ & $10(100 \%)$ & $25(96 \%)$ \\
Havana Decorated & $21(21 \%)$ & $3(20 \%)$ & $2(20 \%)$ & $2(8 \%)$ \\
\hline Hopewell & 0 & 0 & 0 & 0 \\
\hline Havana Fine & $4(4 \%)$ & $4(27 \%)$ & 0 & $1(4 \%)$ \\
\hline
\end{tabular}

2: 1959 Excavation

\begin{tabular}{|l|l|}
\hline Type & $\begin{array}{l}\text { Total Number of Sherds (Percent of } \\
\text { Total) }\end{array}$ \\
\hline Havana Havana Decorated & $74(93 \%)$ \\
\hline Hopewell & $3(4 \%)$ \\
\hline Havana Fine & $2(3 \%)$ \\
\hline
\end{tabular}

3: 1961 Surface Collection 


\begin{tabular}{|l|l|}
\hline Type & $\begin{array}{l}\text { Total Number of Sherds (Percent of } \\
\text { Total) }\end{array}$ \\
\hline Havana Havana Decorated & $69(70 \%)$ \\
\hline Hopewell & \\
\hline Havana Fine & $19(20 \%)$ \\
\hline
\end{tabular}

4: Rim Sherds from 1985 Excavations

\begin{tabular}{|l|l|}
\hline Type & Total Number of Sherds (Percent of \\
& Total) \\
\hline Havana Havana Decorated & $1685(89.5 \%)$ \\
\hline Hopewell & \multicolumn{1}{|c|}{$554(33 \%)$} \\
\hline Havana Fine & $120(6.5 \%)$ \\
\hline
\end{tabular}

5: Total Sherds from Fv 196 
APPENDIX C

DECORATION TOTAL 


\begin{tabular}{|l|l|}
\hline Havana Decoration & Sherds Exhibiting the Decoration \\
\hline Naples Dentate & 300 \\
\hline Zoned & 87 \\
\hline Burnished & 31 \\
\hline Neteler Crescent Dentate & 25 \\
\hline Cordwrapped Stick Dentate & 19 \\
\hline Naples Plain & 18 \\
\hline Naples Ovoid & 14 \\
\hline Neteler Crescent Plain & 8 \\
\hline Hummel Stamped & 7 \\
\hline Fettie Chevrons & 7 \\
\hline Rocker Dentate & 5 \\
\hline Sister Creeks Square Punctate & 3 \\
\hline Rocker Neteler Crescent & 2 \\
\hline Sister Creeks Punctate & 1 \\
\hline Stueben Punctate & 37 \\
\hline Unnamed Decorations & \\
\hline
\end{tabular}

1: Havana Decoration Totals for $\mathrm{F}^{\mathrm{v}} 196$ 


\begin{tabular}{|l|l|}
\hline Hopewell Decoration & Sherds Exhibiting the Decoration \\
\hline Zoning & 26 \\
\hline Naples Dentate & 25 \\
\hline Hopewell Punctate & 12 \\
\hline Crosshatched Rim & 12 \\
\hline Rocker Dentate & 5 \\
\hline Zoned Red Slip & 4 \\
\hline Montezuma Punctate & 2 \\
\hline
\end{tabular}

2: Hopewell Decoration Totals for $\mathrm{F}^{\mathrm{v}} 196$

\begin{tabular}{|l|l|}
\hline Havana Fine Decoration & Sherds Exhibiting the Decoration \\
\hline Naples Dentate & 26 \\
\hline Zoned & 11 \\
\hline Burnished & 9 \\
\hline Incised/Chevron & 8 \\
\hline Rocker Dentate & 6 \\
\hline Hummel Stamp & 1 \\
\hline
\end{tabular}

3: Havana Fine Decoration Totals for $\mathrm{F}^{\mathrm{v}} 196$ 
APPENDIX D

CERAMIC SERIES AND

DECORATION TYPES 
Black Sand and Morton Sherds

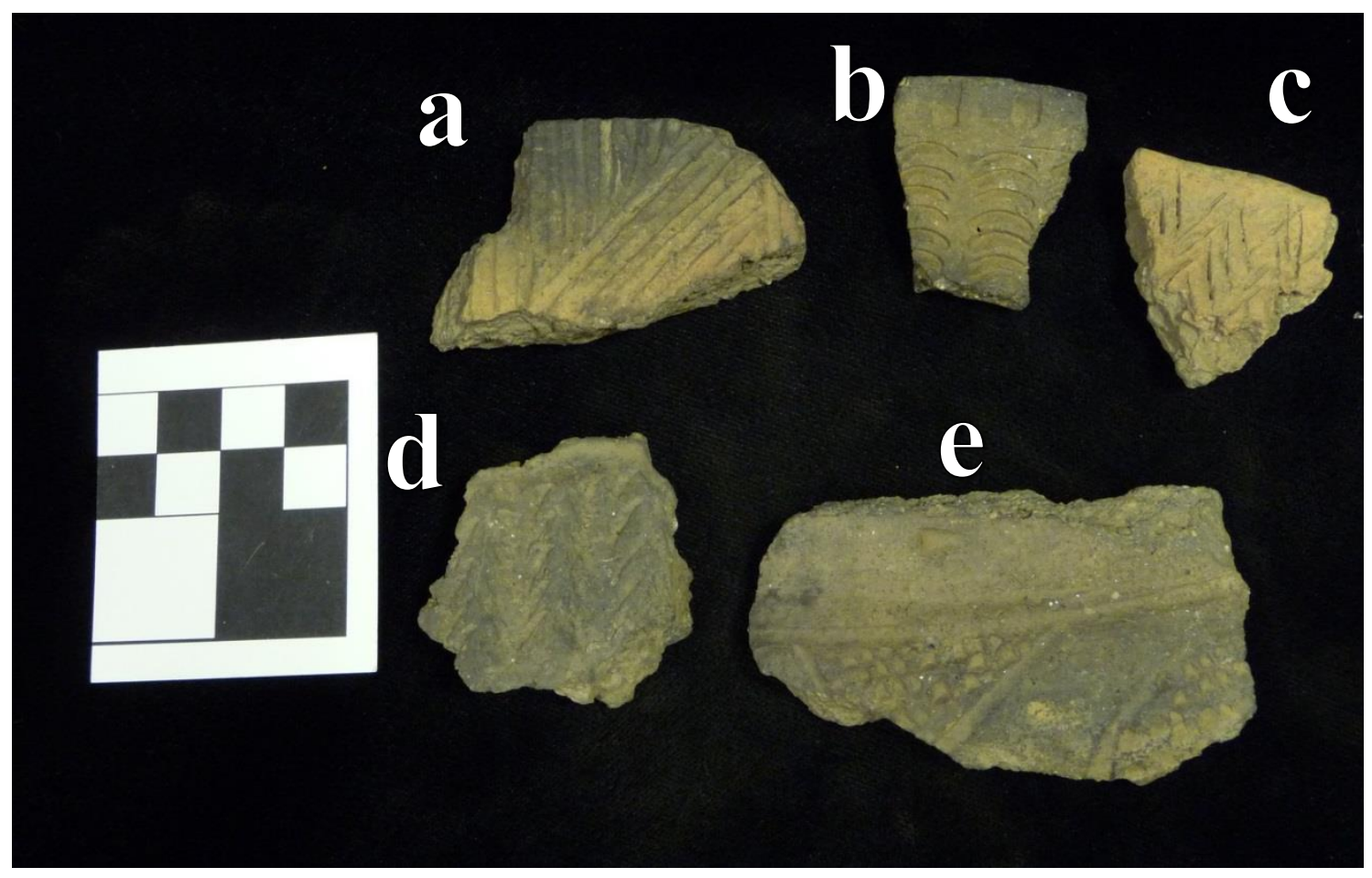

(a) Mixed trait (Black Sand/Morton/Hopewell) fine sherd with Black Sand Incising (b)

Fine Morton Sherd with Neteler Plain stamps (c) Morton Sherd with incised Fettie Chevrons (d) Black Sand/Morton sherd with Sister Creeks Fingernail Punctations (e) Mixed trait (Morton/Hopewell) sherd with Hopewell Zoned, Naples Dentate, and Hopewell Punctations (Collection of Illinois State Museum). 
Black Sand and Havana Fine Sherds

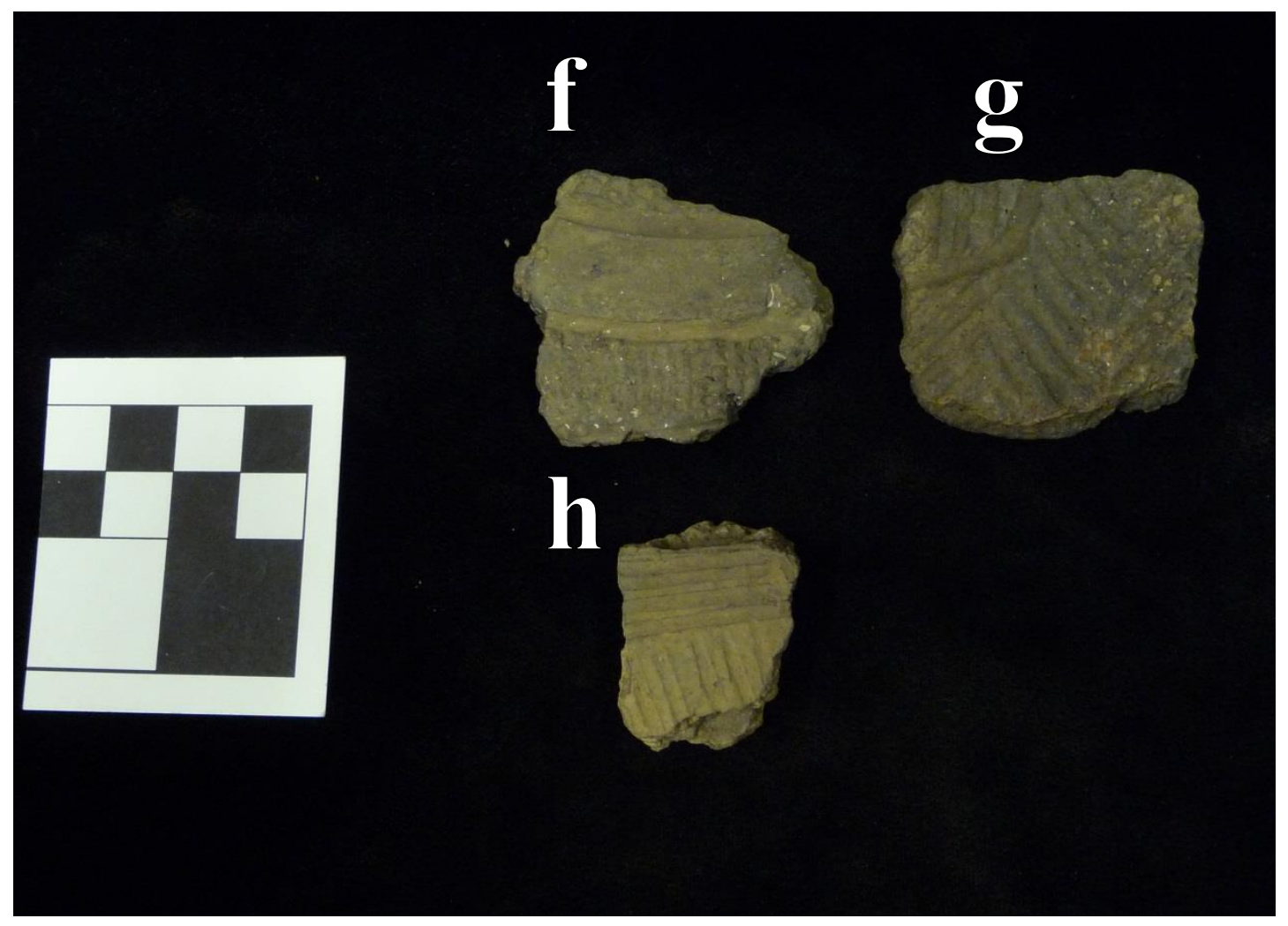

(f) Havana Fine sherd with shell temper and Zoned Naples Dentate stamping (g) Black Sand sherd with Fettie Chevrons (h) Morton sherd with Black Sand Incising (Collection of Illinois State Museum). 


\section{Havana Sherds}

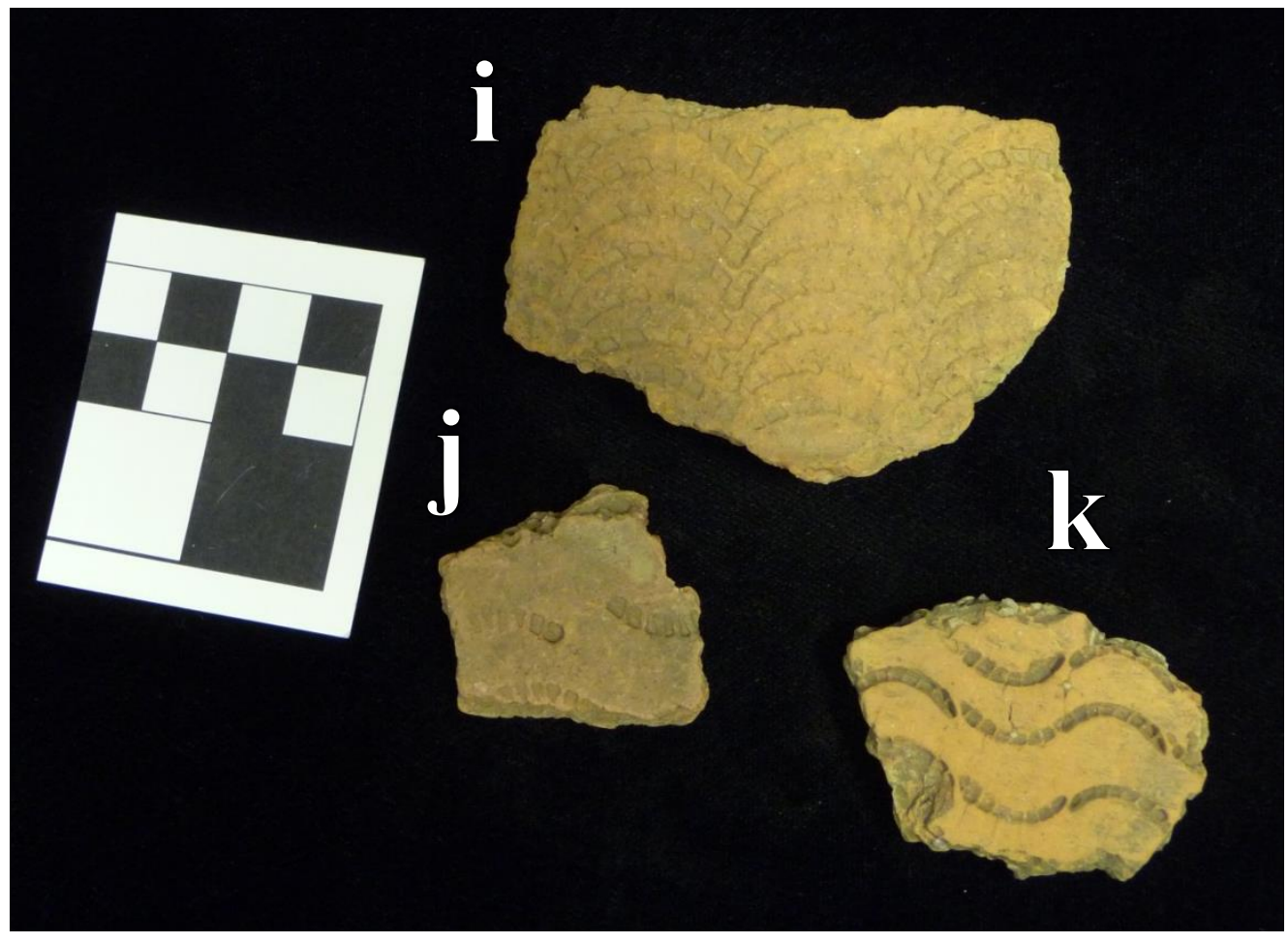

(i) Havana sherd with dentate Neteler Crescents (j, k) Havana sherd with alternating orientation dentate Neteler Crescents (Collection of Illinois State Museum). 


\section{Havana Sherds}

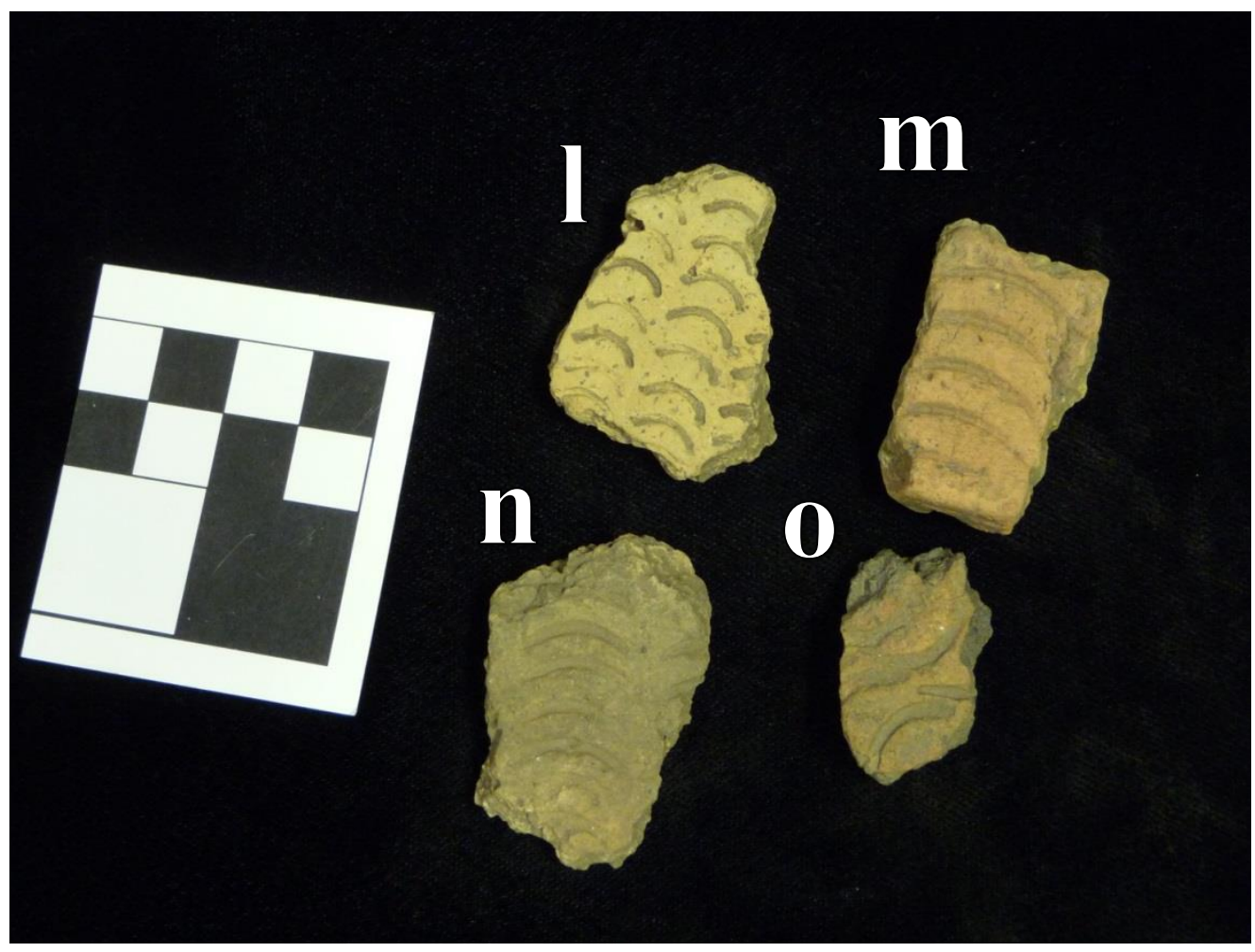

(1-n) Havana sherd with plain Neteler Crescents (o) Havana sherd with alternating orientation plain Neteler Crescents (Collection of Illinois State Museum). 


\section{Havana Sherds}

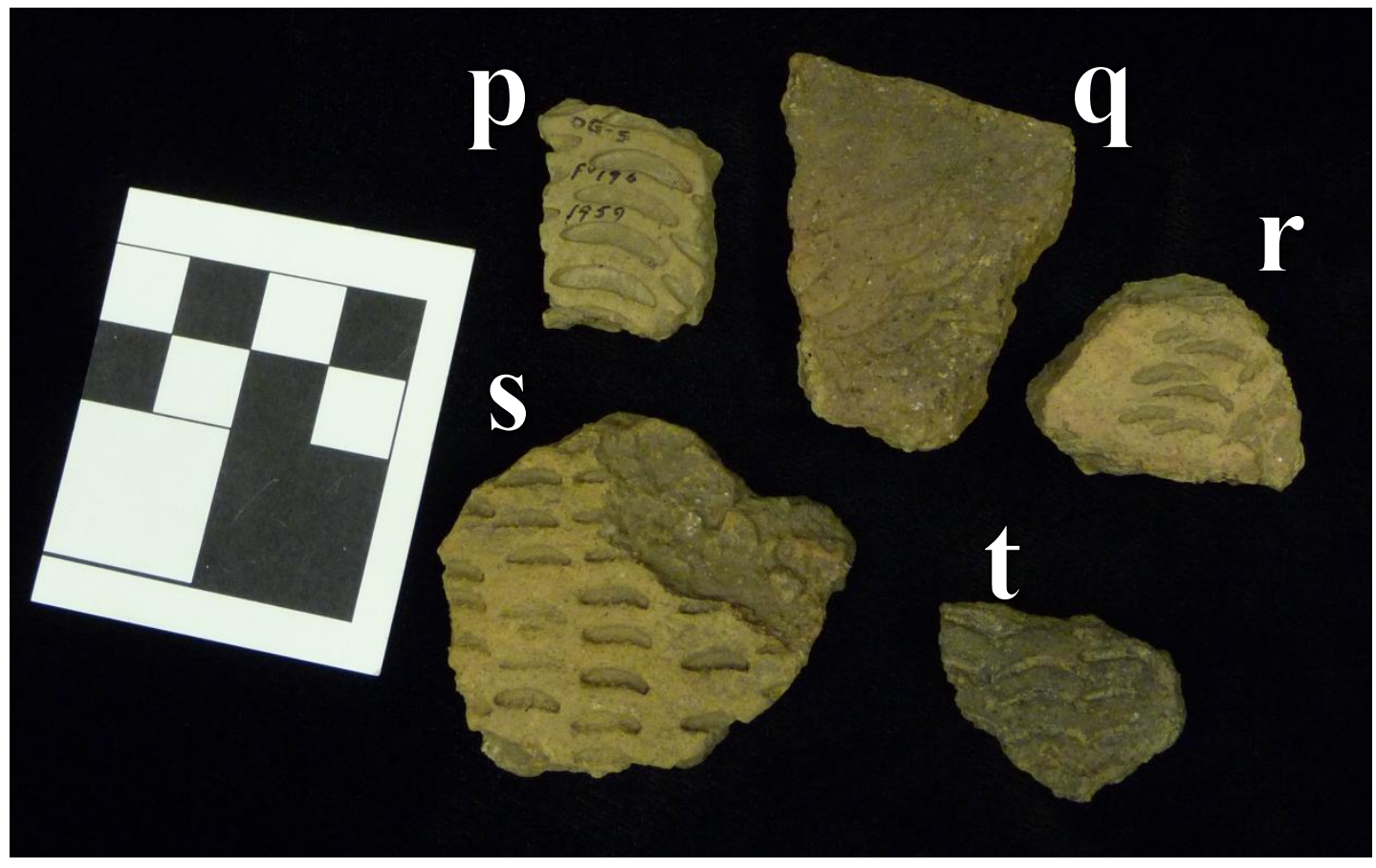

(p, s) Havana sherd with Hummel Stamp (q) Havana sherd with Zoned Neteler Crescent

(r) Havana sherd with Rocker Neteler Crescent (t) Havana sherd with plain Neteler

Crescents (Collection of Illinois State Museum). 
Havana Sherd

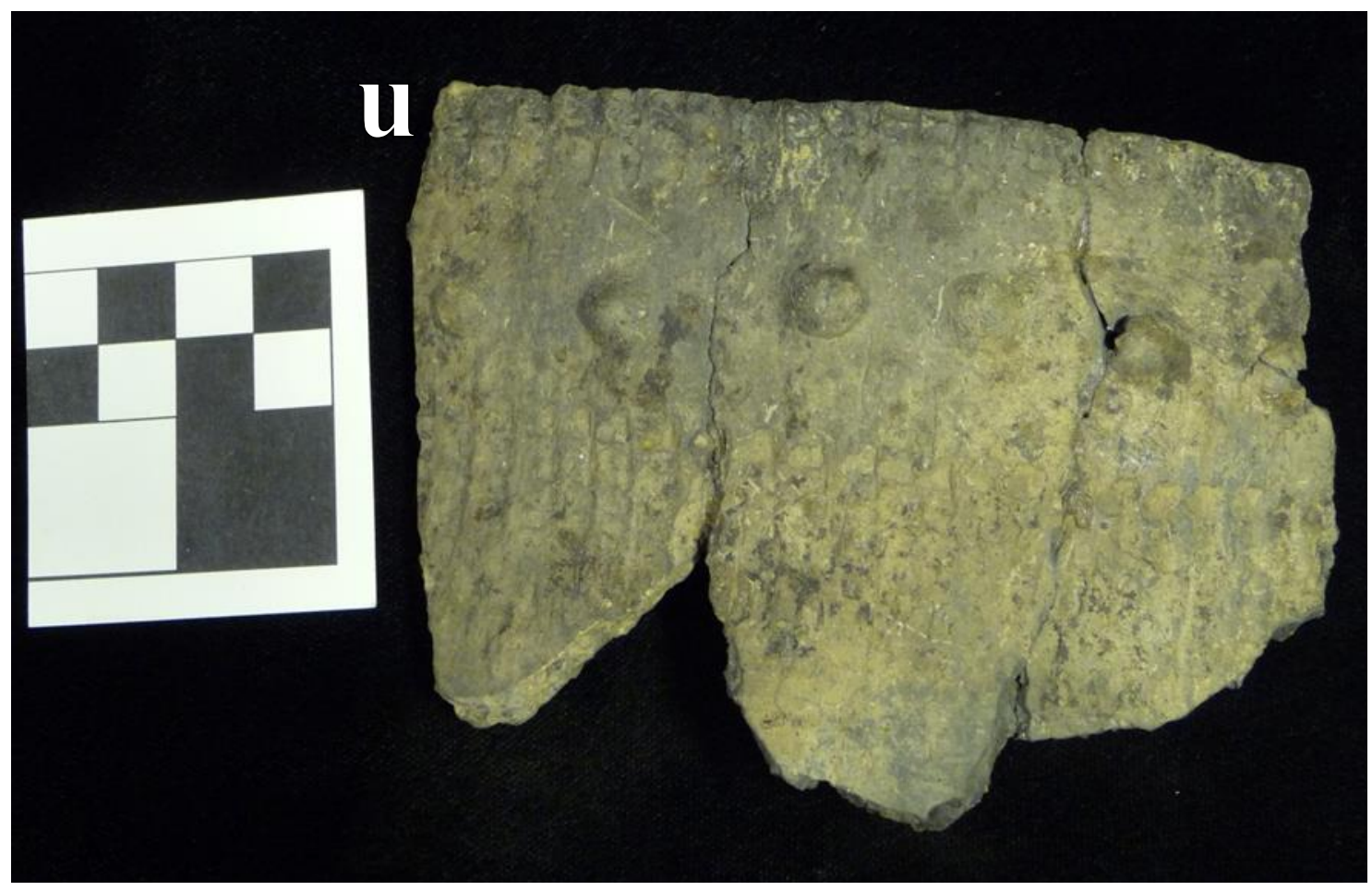

(u) Havana rim sherd with Nodes and Naples Dentate (Collection of Illinois State

Museum). 


\section{Havana Sherds}

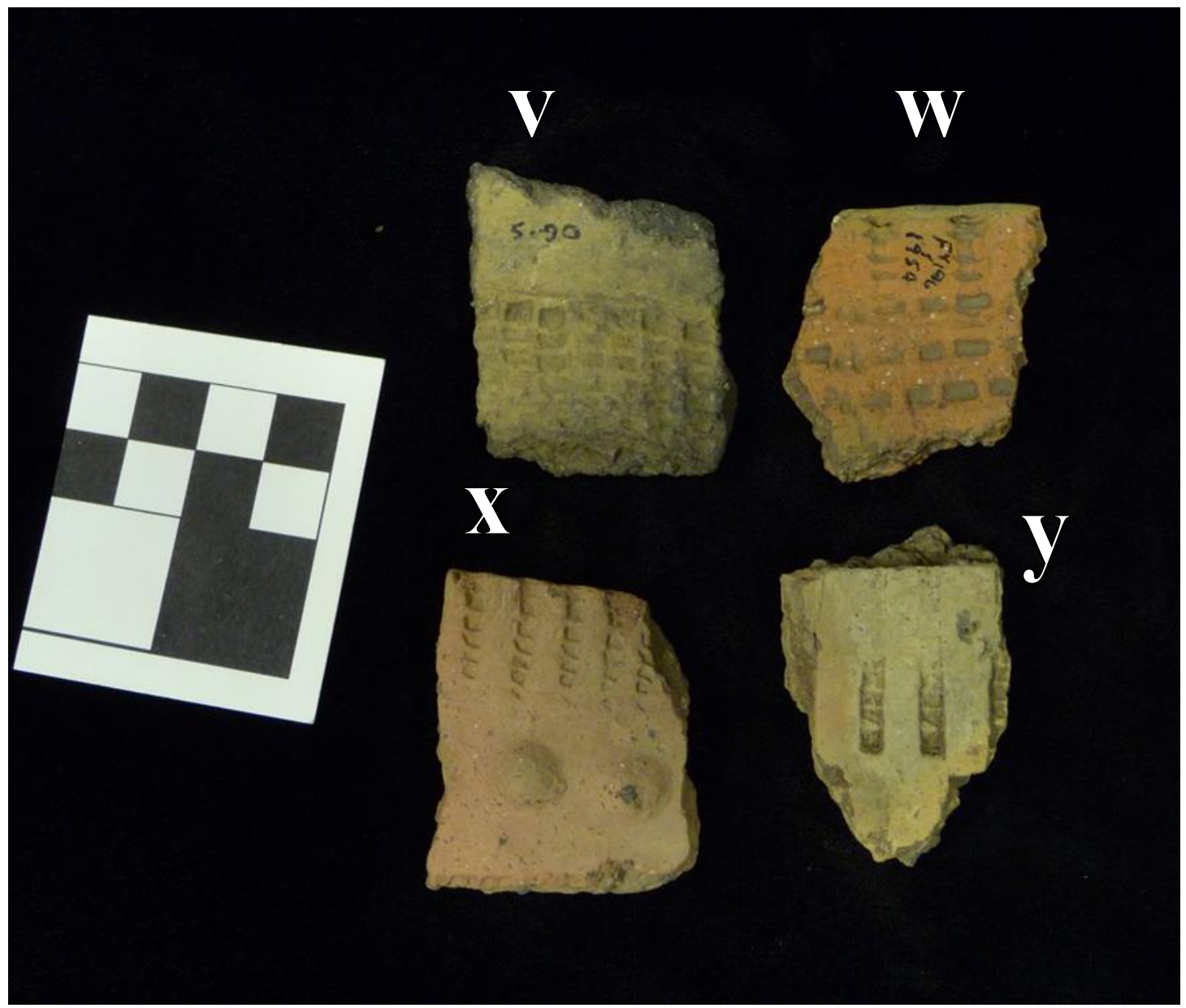

(v, y) Havana sherd with Zoned Naples Dentate stamping (w) Havana sherd with Naples

Dentate and Cordwrapped Stick Dentate (x) Havana rim sherd with Nodes and Naples Dentate (Collection of Illinois State Museum). 


\section{Havana Sherds}

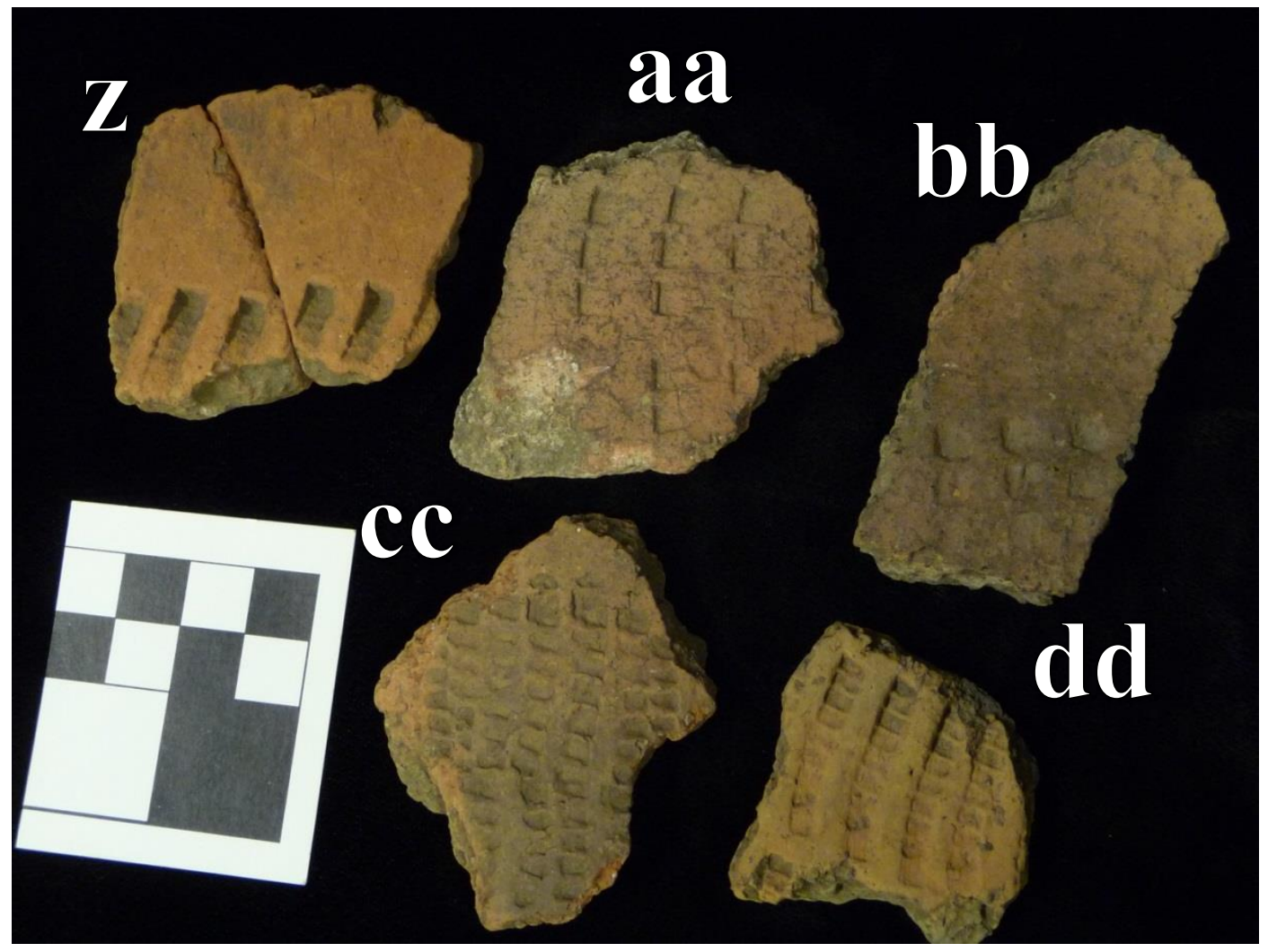

(z, aa-dd) Havana sherd with Naples Dentate (Collection of Illinois State Museum). 
Havana Sherd

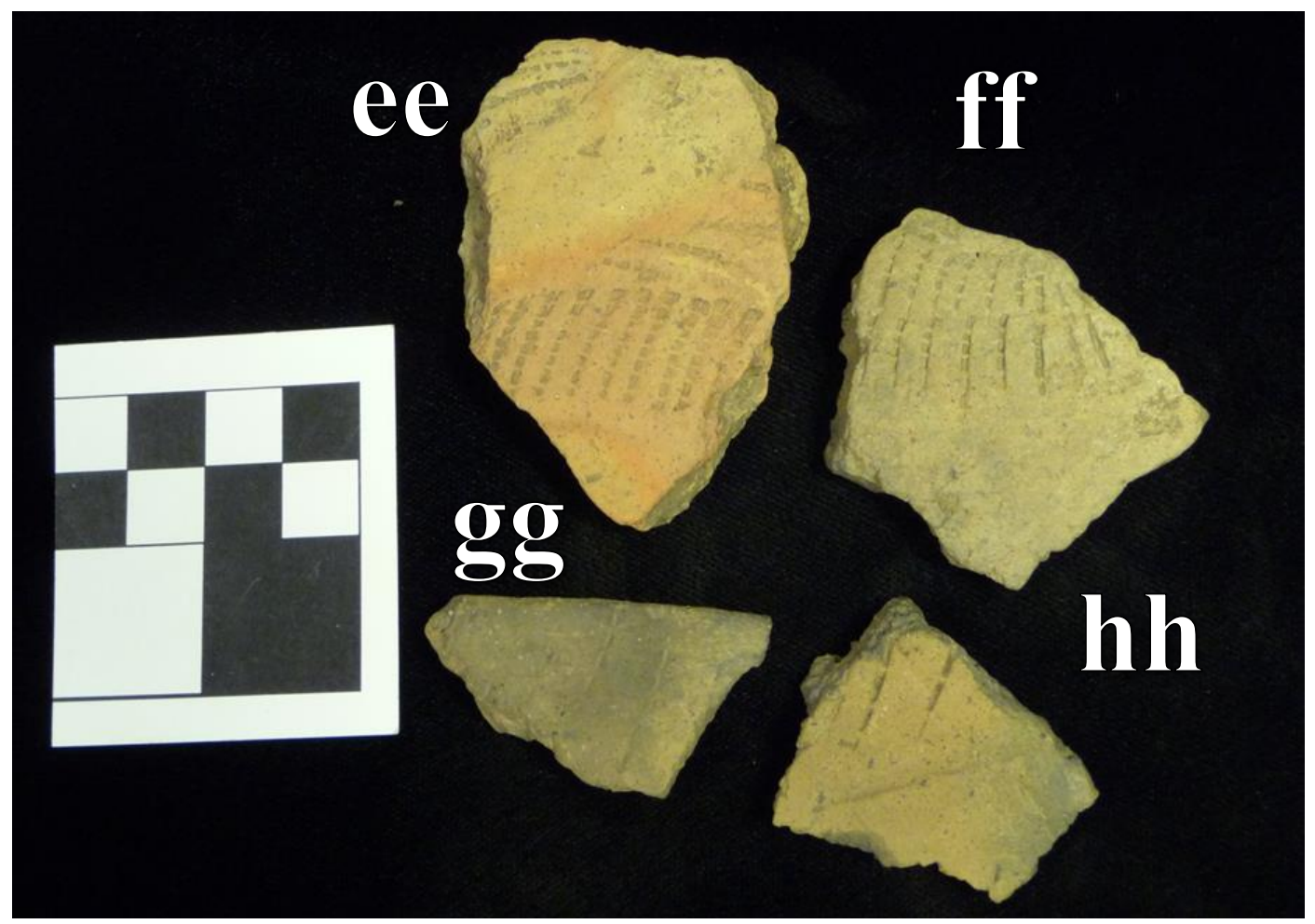

(ee, hh) Havana sherd with Zoned Naples Dentate (ff, gg) Havana sherd with Naples Dentate (Collection of Illinois State Museum). 


\section{Havana Sherds}

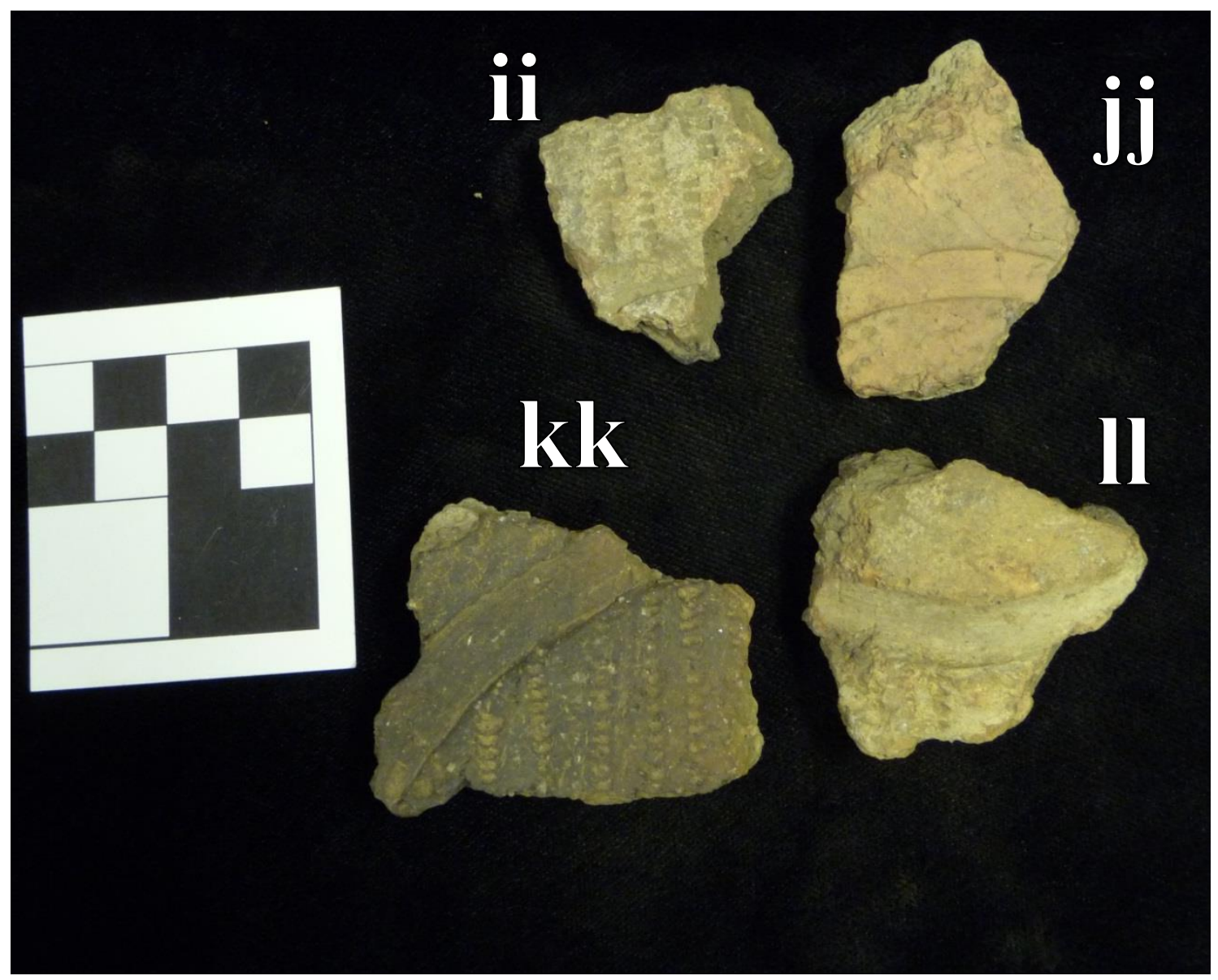

(ii, kk) Havana sherd with Zoned Cordwrapped Stick Dentate (jj, 11) Havana sherd with Zoning (Collection of Illinois State Museum). 


\section{Havana Sherds}

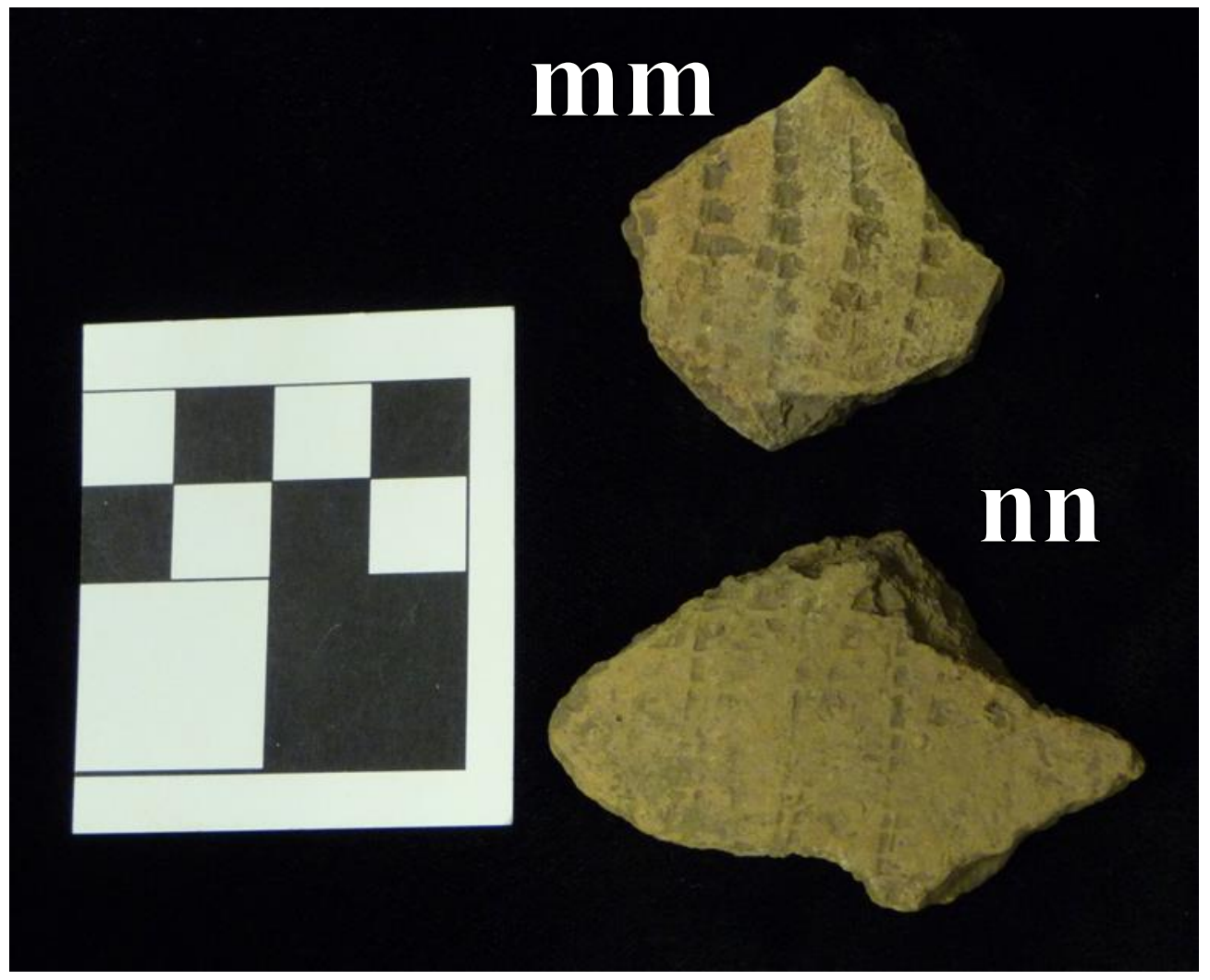

(mm, nn) Havana sherd with dentate Rocker Stamping (Collection of Illinois State Museum). 


\section{Havana Fine sherd}

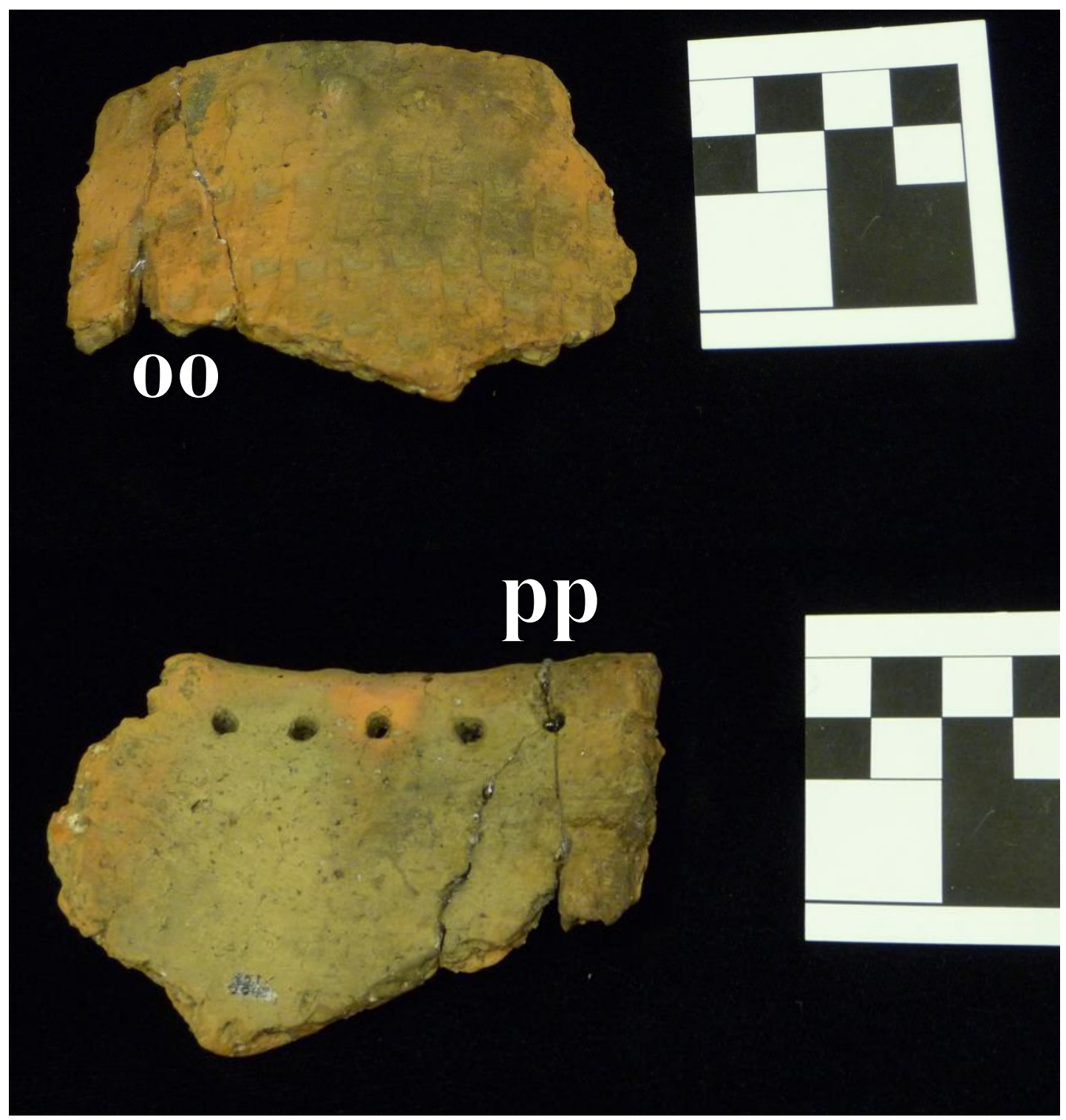

(qq) Havana Fine sherd with Nodes and Naples Dentate. (pp) Interior surface of Havana

Fine sherd (Collection of Illinois State Museum). 
Hopewell Sherds

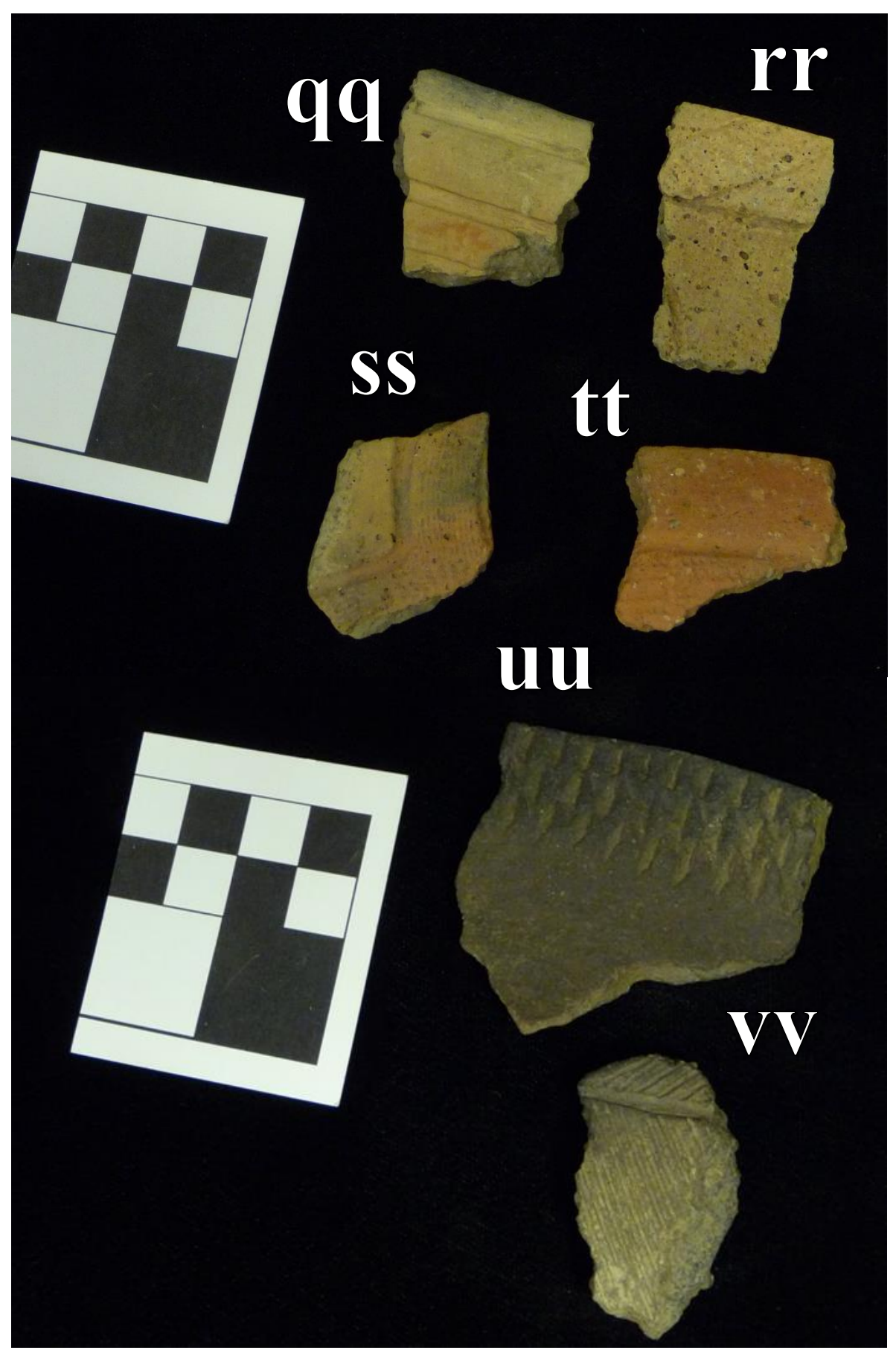

(qq) Hopewell sherd with Zoning (rr) Hopewell sherd with limestone temper and Zoning (ss, tt) Hopewell sherd with Zoned Naples Dentate (uu) Hopewell sherd with Montezuma Punctate (vv) Hopewell sherd with Zoned Incising (Collection of Illinois State Museum). 


\section{Havana Sherds}

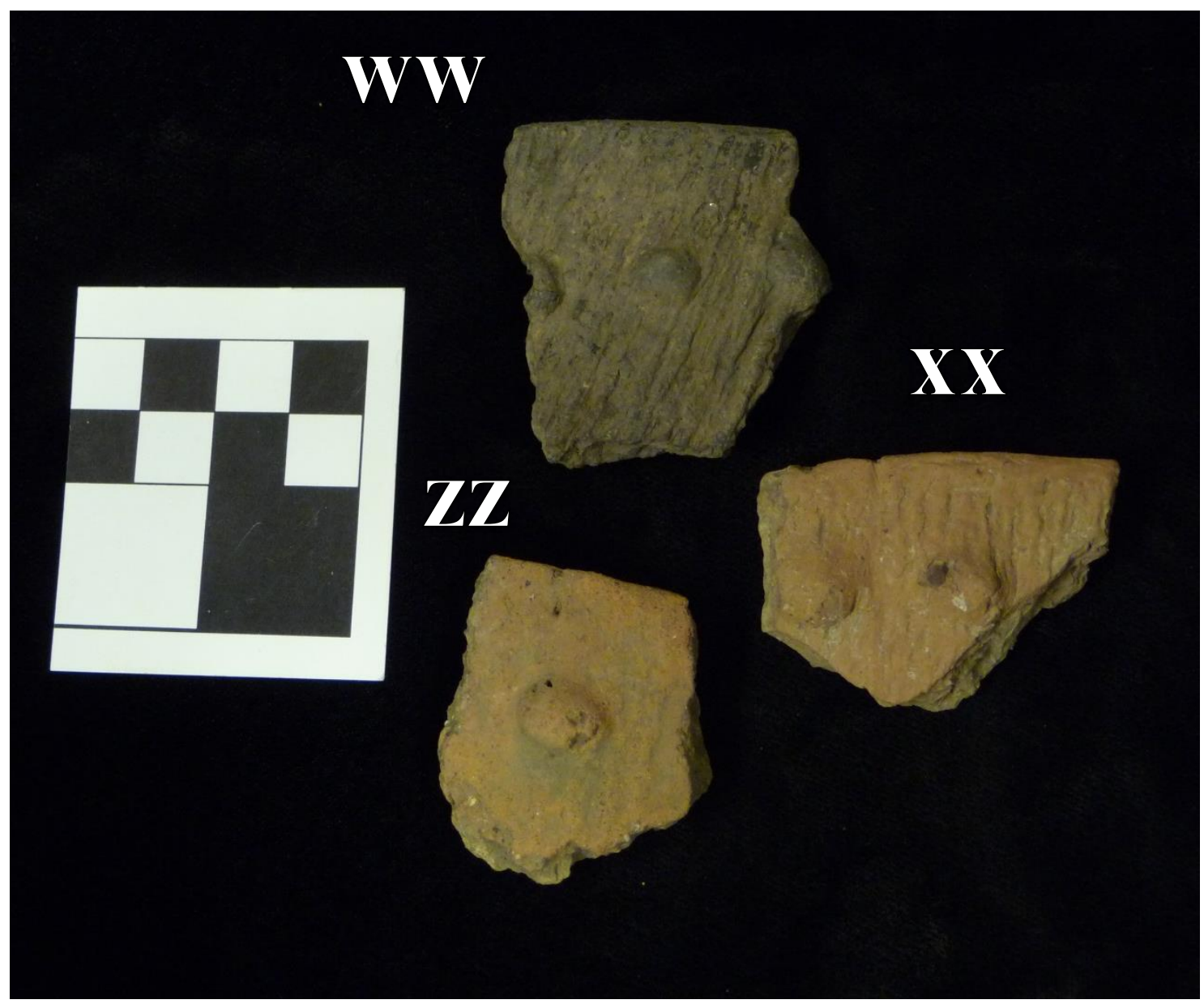

(ww-zz) Undecorated Havana rim sherd with Nodes and Cordmarking (Collection of Illinois State Museum). 